GOWANS'S NATURE BOOKS.NO14. GONET

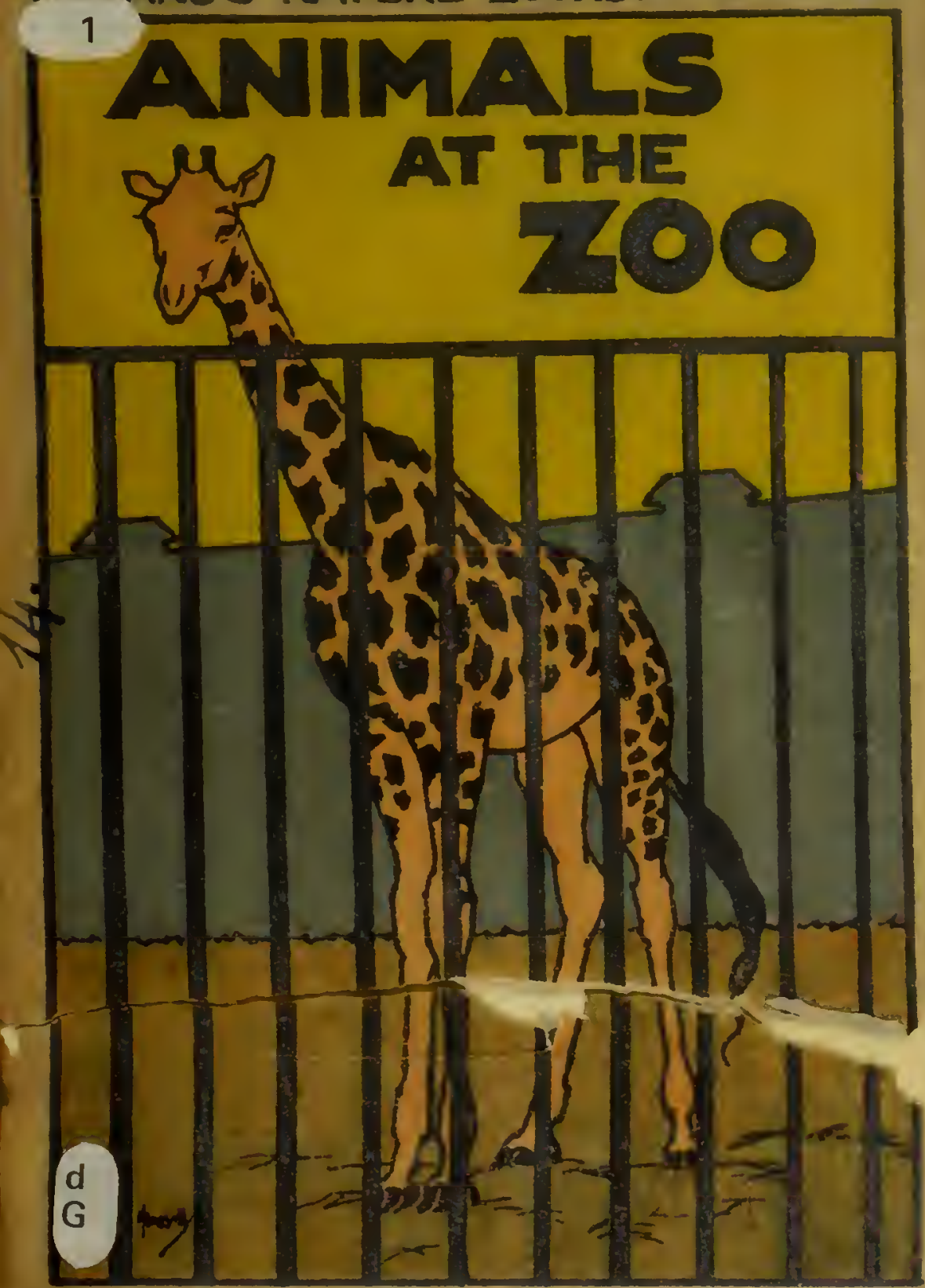

LONDON \& GLASGOW. GOWANS \& GRAV, LTP 
Presented by the Executors of Norman Douglas Simpson I 890 - I974 


\section{Gowans's Nature Books}

$\mathrm{T}^{\mathrm{HE}}$ object of these little books is to stimulate a love for nature and a desire to study it.

The first volumes of the series have been extremely successful, and the publishers hope to make the others equally interesting and beautiful.

No. r.-WILD BIRDS AT HOME. Sixty Photo. graphs from Life, by Chas. Kirk, of British Birds and their Nests.

No. 2.-WILD FLOWERS AT HOME. First Series.

Sixty Photographs from Nature, by Cameron Todd. No. 3.-WILD FLOWERS A'T HOME. Second Series, by the Same.

No. 4.-BUTTERFLIES AND MOTHS AT HOME. Sixty Photographs from Life, by A. Forrester.

No. 5.-WILD BIRDS AT HOME. Second Series, by Charles Kirk.

No. 6.-FRESHWATER FISHES. Sixty Photographs from Life, by Walford B. Johnson and Stanley C. Johnson, M.A.

No. 7.-TOADSTOOLS AT HOME. Sixty Photographs of Fungi, by Somerville Hastings, F.R.C.S.

NO. 8.-OUR TREES \& HOW TO KNOW THEM. Sixty Photographs by Charles Kirk.

No. 9. -WILD FLOWERS AT HOME. Third Series.

By Somerville Hastings, F.R.C.S.

No. ro.-LIFE IN THE ANTARCTIC. Sixty Photographs from Life by Members of the Scottish National Antarctic Expedition.

No. II.-REPTILE LIFE. Sixty Photographs from Life, by Walford B. Johnson and Stanley C. Johnson, M.A.

No. I2.-SEA-SHORE LIFE. Sixty Photographs by the Same.

No. r3.-BIRDS AT THE ZOO. Sixty Photographs from Life, by W. S. Beveridge, F.Z.S.

No. I4.-ANIMALS AT THE ZOO. Sixty Photographs by the Same.

Others in Preparation.

price 6o. Net. each Volume, postage 10. each.

GOWANS \& GRAY, Ltd., London \& Glasgow 


\section{Gowans's Books for the $Y$ oung}

A SERIES of prettlly got up little volumes contalning old favourites and other books sure to become favourites.

Ready.

NO. 8. -THE SEVEN CHAMPIONS OF CHRISTENDOM. By W. H. G. Kingston.

No. 2. THE HEROES. Greek Fairy Tales for my Children, by Charlea Kingsley.

No. 3. THE STORY OF PRINCE AHMED AND THE FAIRY PERIE BANOU (from the Arabian Nights).

Others in Contemplation.

Price, Piotuge Borros, Cloth Back, bo. Net. postage, 10.

GOWANS \& GRAY, Ltd., London and Glasgow

Natural History Museum Library

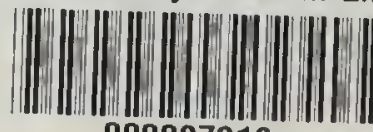




\section{Die besten Gedichte}

\section{der deutschen Sprache}

Erstes Hundert. Lyrik

HERAUSGEgEBen VON ROLF LEMBECK

Eine Auswahl der schönsten deutschen Gedichte ist hier zu einen Bändchen vereint, das wegen seiner reizenden Ausstattung und wegen des ausserordentlich niedrigen Preises sich viele Freunde erwerben wird.

Prices: Paper, 6d. net. Cloth, is. net. Leather, 2s. net. Postage, Id.
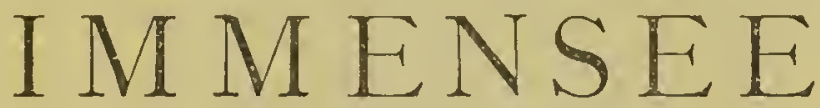

A SHORT STORY

From the German of THEODOR STORM

The Original has passed through over FORTY Editions in Germany, and is considered by many

TIIE FINEST SHORT STORY EVER WRITTEN Price: Art Cloth, 6al. net. Postage, $\mathrm{I} \frac{1}{2} d$.

GOWANS \& GRAY, LTD., LONDON AND GLASGOW 


\title{
POCKET ANTHOLOGIES
}

Complled by ADAM L. GOWANS, M.A.

seth Thousand.

No. 1.- The Hundrod Best Poems (Lyricai) in the Eaglish Language.

1Cth Thousand.

No. 2. The Hundred Best Poems (Lyrical) in tho English Language. Socond Serles.

Ith Thousand.

No. 3.-Tho Beok of Love. One buadred of the best love-poems in the English language.

6th Thousand.

No. 4.-The Hundred Best Blank Vorse Passages in the Englich Language.

\section{Just Publlshod.}

No. 5.-l'oetry for Chlldren. One hundred of the best poems for the young in the English langunge.

$$
\text { In Proparation. }
$$

No. 0. - The Ways of God. An unconventional anthology of poems on the great problems of existence.

others in Contemplation.

\author{
PRICES : \\ Paper, 6d. Net. \\ Cloth, is. Net. \\ Loather, 2s. Net. Postage, Id. each.
}

GOWANS \& GRAY, Ltd., London \& Glasgow, 


\section{Gowans's Nursery Pictures}

THE publishers believe that the complete novelty of a series of four coloured pictures by $\mathrm{Mr}$. Stewart Orr, which they have just published will ensure their immediate success. Nc similar series is in existence, and the attractive appearance of the prints will delight every child who is presented with them. They are supplied in neat brown paper frames, ready to bang up, at Sixpence each, net, Postage. threepence extra.

THE FOUR SUBJECTS ARE:

\section{OLD MOTHER GOOSE} MUMPTY-DUMPTY

TOM THE PIPER'S SON THREE BLIND MICE

The pictures are to be had through any bookseller, printseller, or stationer, or direct from the publishers, GOWANS \& GRAY, Ltd., 58 Cadogan St., Glasgow 


\section{Humorous Masterpieces}

FACH volume contains Sirty of the very best Drawings of the undermentioned Masters of Humorous Illustration.

READY

No. 1.-PICTURES BY JOHN LEECH

FIRST SERIES

These pictures are not old fantioned. They are 25 turny to-day as when they were first publislied.

No. 2.-PICTURES BY GAVARNI

Examples of ore of the greatest French Humunists.

INO. 3.-PICTURES BY JOHN LEECH

SECOND SERIES

Just 25 groul as the first seried.

No. 4.-PICTURES BY ROBERT SEYMOUR

clever Illustrations by a great Artist, too little ksown.

No. 5.-PICTURES BY PHIL MAY

Sixty of his best.

Others in Preparation

Price 6D. Net. e.aoh Volume (Post fiRe 70.)

GOWANS \& GRAY, Ltd., London \& Glasgow 


\section{The Children's Bookshelf}

PRETTYY little Books with about a dozen coloured lilustratioas by well-known artists.

No, x, -THE UGLY DUCKLING, by Hans Andersen. Coloured illustrations by Stewart Orr.

No. 2.-LITTLE KLAUS AND BIG KLAUS, by Hans Andersen. Coloured illustrations by Charles Pears.

No. 3. THE PIED PIPER OF HAMELIN, by Robert Browning. Coloured illustrations by Charles Robinson.

No. 4. -THE STORY OF CHANTICLEER. Re-told from Chaucer, by R. Brimley Johnson. Coloured Illustrations by Stewart Orr.

Price, bo. Each in Parchiment Coverb. Post free 7 d.

GOWANS \& GRAY, Ltd,, London \& Glasgow 


\section{Gowans's International Library}

Neatly Painted. and in Paetty Parchinent Covers.

No. 1. -The Haunted and the Haunters, by Lord Lytton, has been called, and probably is, the best ghost story in the world.

No. 2.-The Heavenly Footman, by Joln Bunyan. A sermon, but one which the picturesque, racy, and thoroughly original style of its great author raises far above tlre common, and inakes as interesting as "The Pilgrim's Progress."

No. 3.-The Marriage Ring, by Jeremy Taylor. The famous treatise on Marriage and its duties, by one of the very greatest writers of English prose.

No. 4.-The Lady of Lyons, by Lord Lytton. This famous play has held the stage since it was first acted. It contains the well-known passage "A palace lifting to eternal summer," etc.

No. 5.-The Tower of Nesle, a Play by Atex. Dumas the Elder. This romantic play is as intenscly exciting and interesting as "The Three Musketeers."

No. 6.-Everyman. The famous morality play; which is performed so often nowadays.

No. 7. - Goblin Market and other Poens, by Christina Rossettl. A reprint of the first edition of 1862 . Contains some of the most beautiful lyrics in the language.

No. S. -Les Chef3-d'CEuvre ly-tques de Rousard et de son Ëcole. This volume contains all the very best poems of the Pleiad, and the selection has been made by the well-known l'rench poet and critic, M. Auguste Dorchain. A treasure for every student of French literature.

No. 9. - The Birds of Artstophanes. The most cliarming comedy of antiquity.

Palce, 6o pret. Pea Volume. post faee 7 d. Each. 
Gowans's Nature Books, No. 14

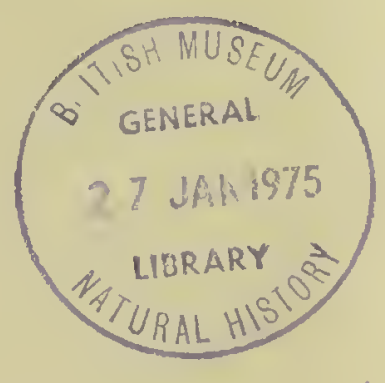

Animals at the Zoo 


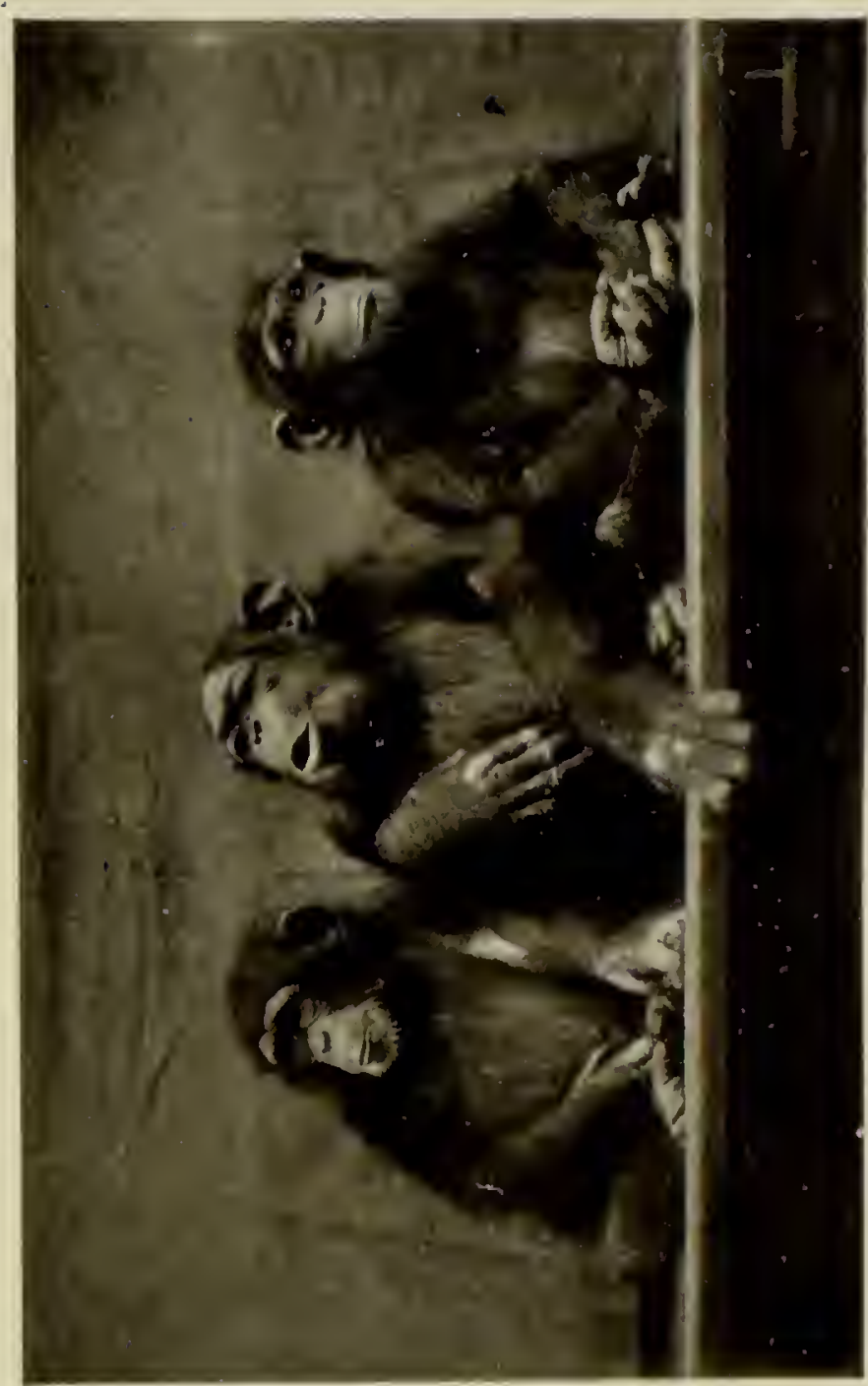

वें

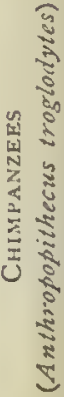




\section{ANIMRLS}
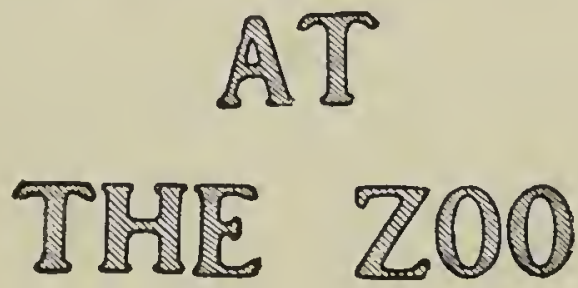

Sixty photographs by W. S. Berridge, F.Z.S.

GOWANS \& GRAY, LTD.

5 Robert Street, Adelphi, London, W.C.

5S Cadogan Street, Glasgow 


\section{AGENTS FOR THE SALE OF THIS SERIES}

France: A. Perche, 45 Rue Jacob, Paris.

Germany: W. IVeicher, Windmïhlenver, I. III, Leipzig.

Savitzeland: E. Frankfurter, 12 Grand-Chine, Lansanne.

Belgium: Spineux \&o Cie, 3 liue du bois.Samoge, Brussels.

Scandinavia: A. \&o O. Schedir, Lund, Siveden.

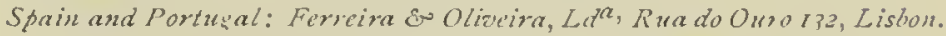
Holland: Kirberger Bo Kesper and Jacs. G. Rotbers, Ansteriam.

A. Abrahams, The Hague.

Anerica: Dodge Publishing Company, 40-42 East roth Street, Ncav Iork. 
$\Gamma^{T}$ is hoped that these sixty photographs, besides forming a most miteresting and tangible memento of aisits to the London Zoo and similar inslitulions, will be of great educative value for the study of Natural History. The order is that of Lyueker"s "lioyal Natural History;" the nomenclature that of the Zoo labels, except in a few cases where Lyuekker is followed. 


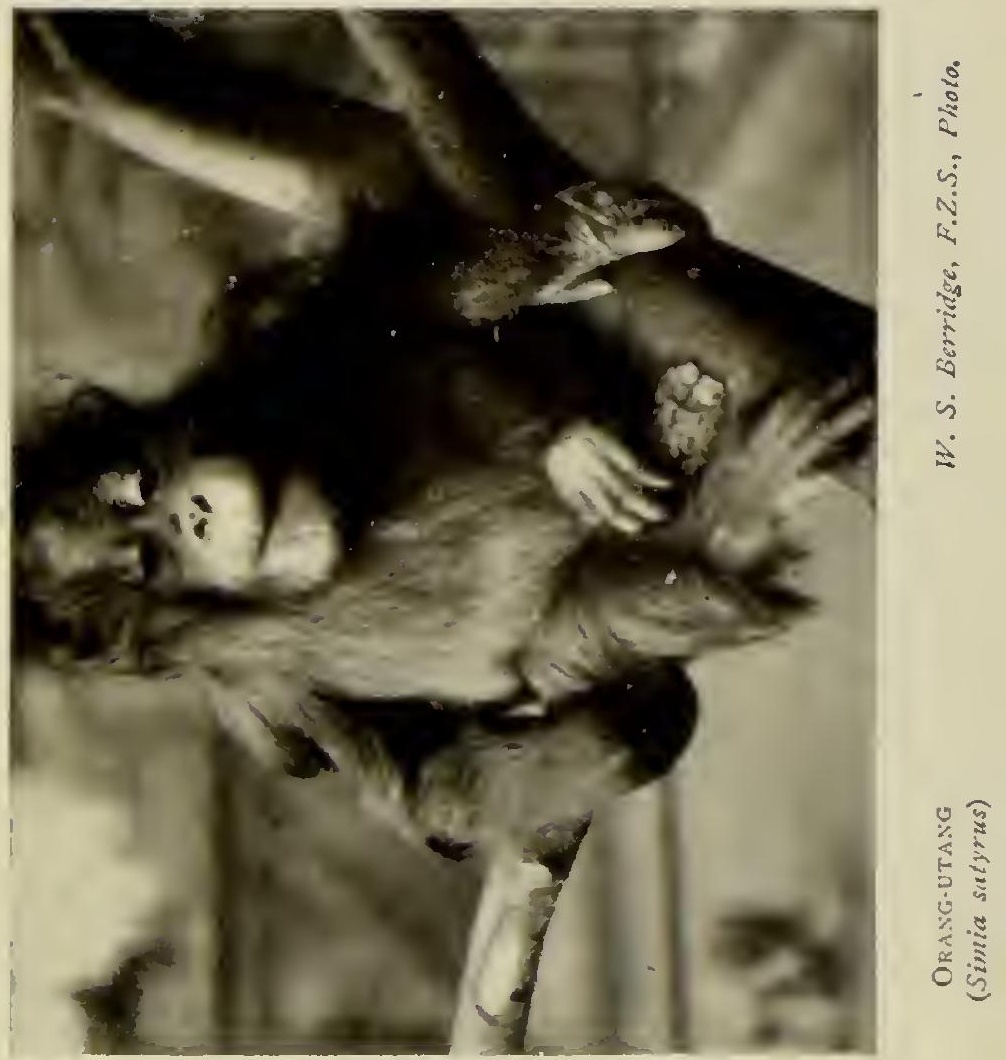




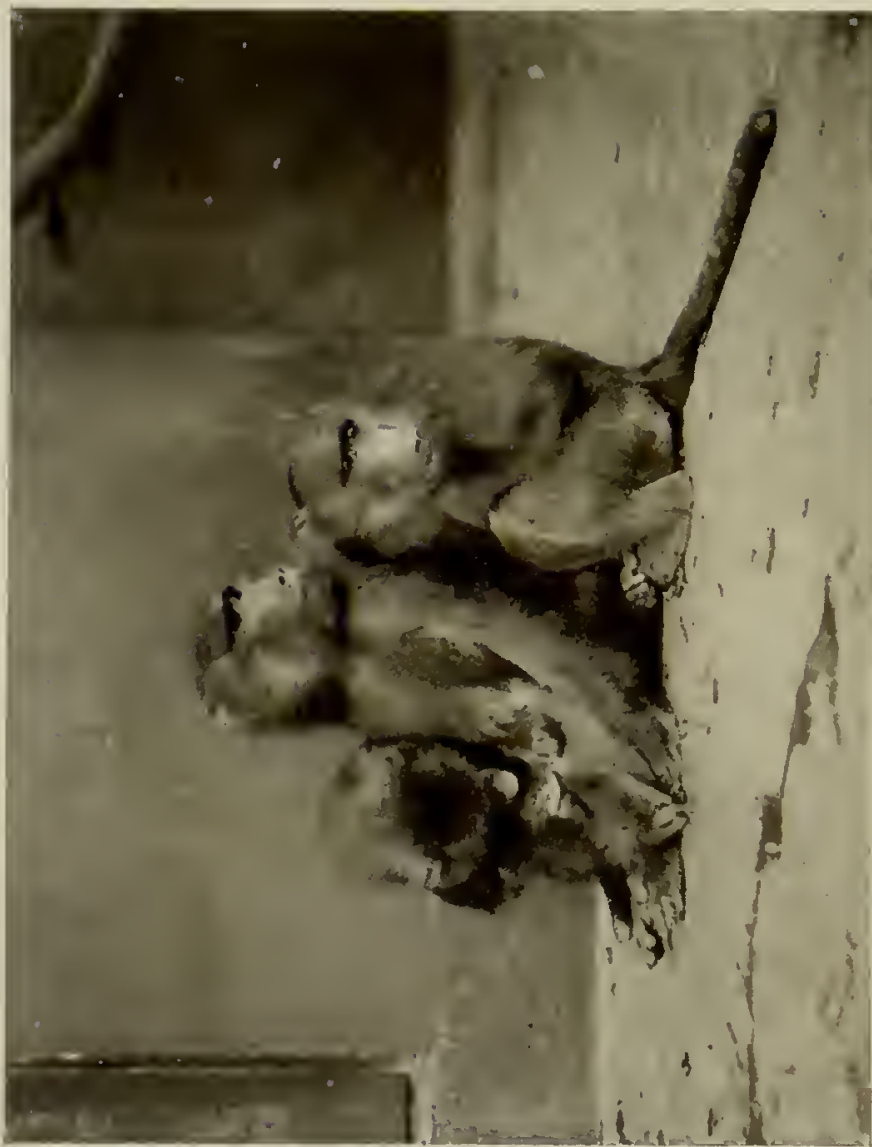

हैं

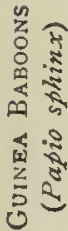




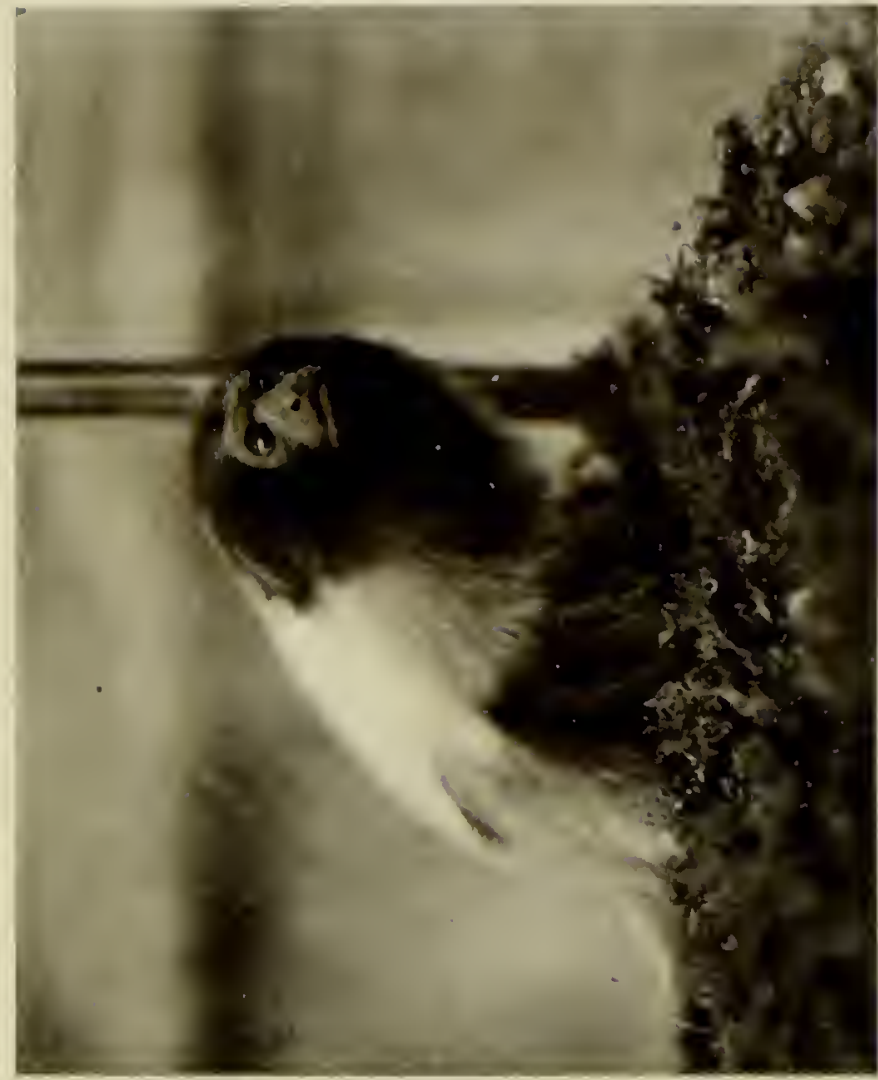

हैं

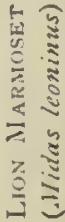




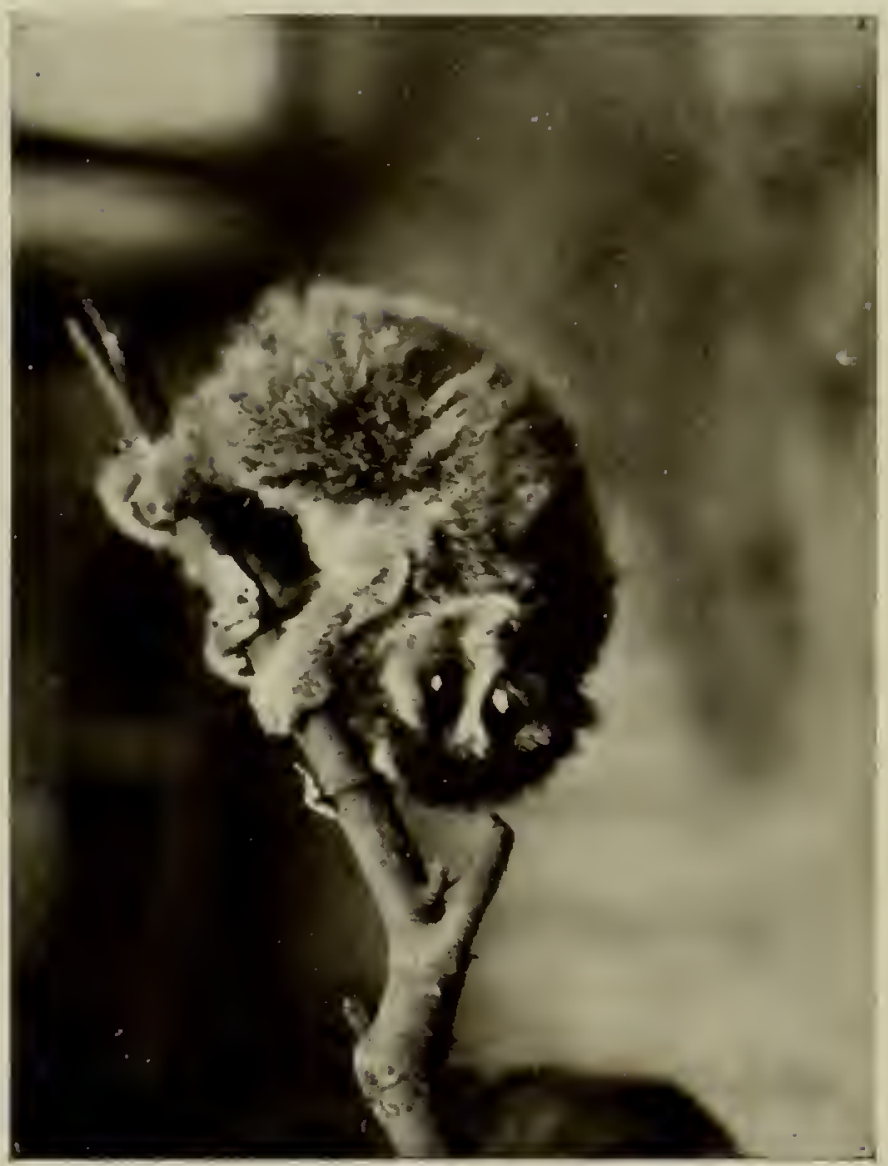

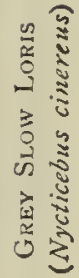




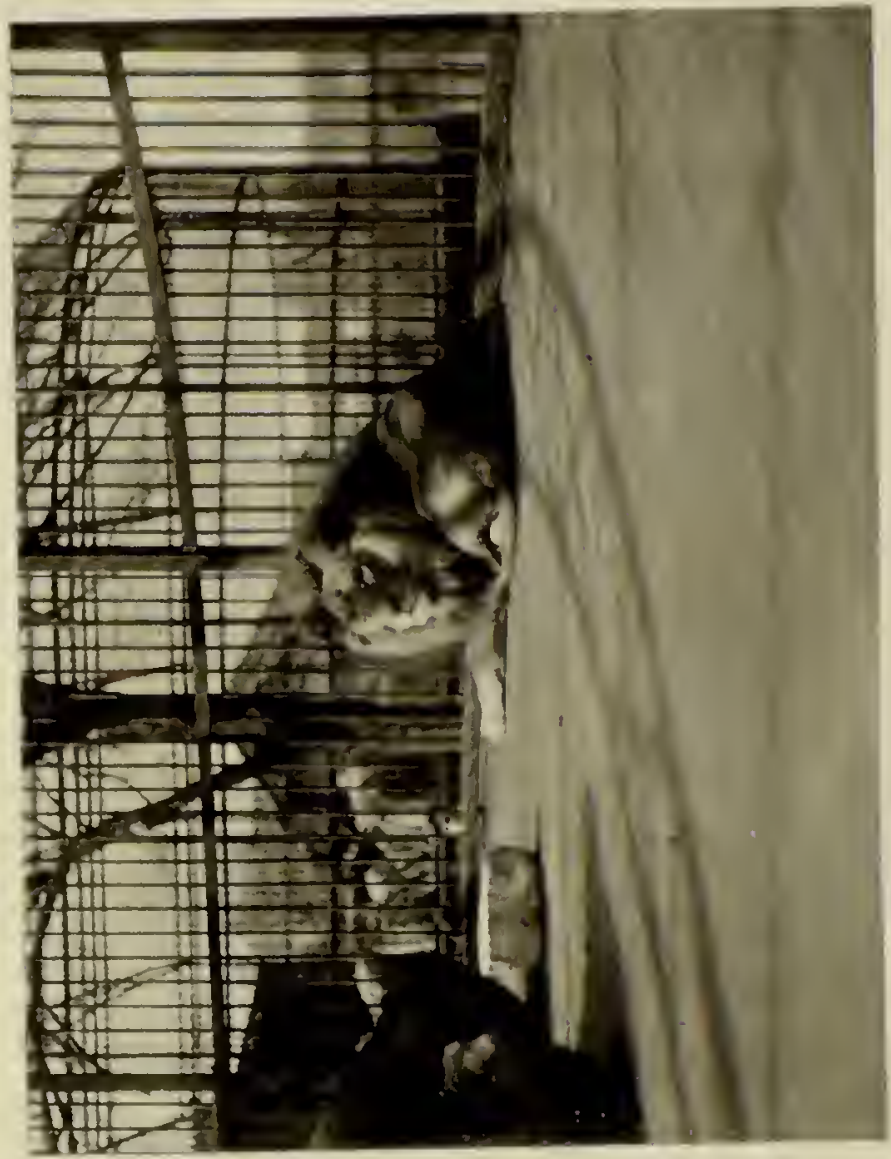

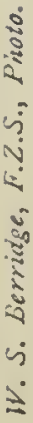

$z=\frac{8}{2}$ 


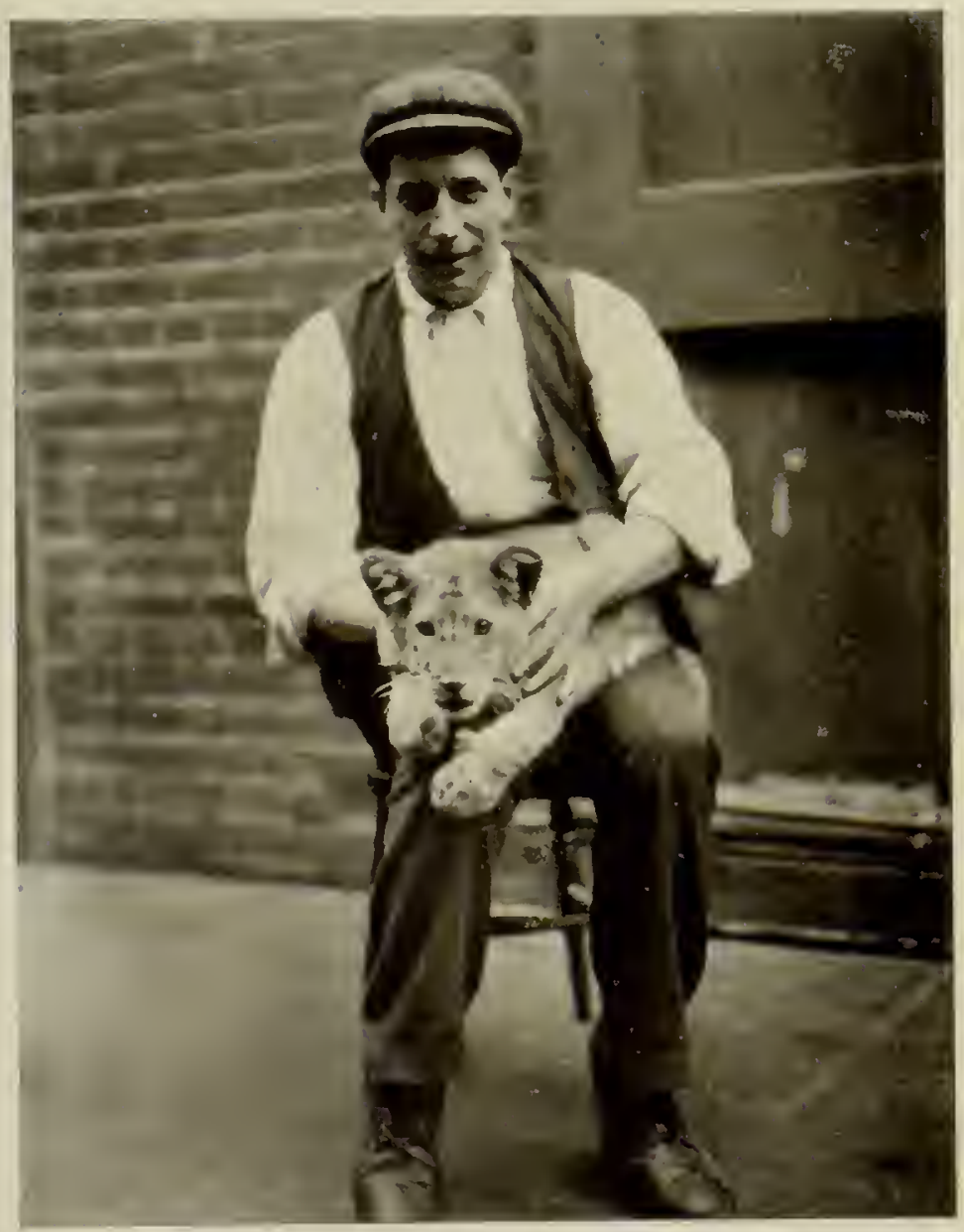

LiON CUB (Io weeks old) W. S. Berridge, F.Z.S., Photo. 


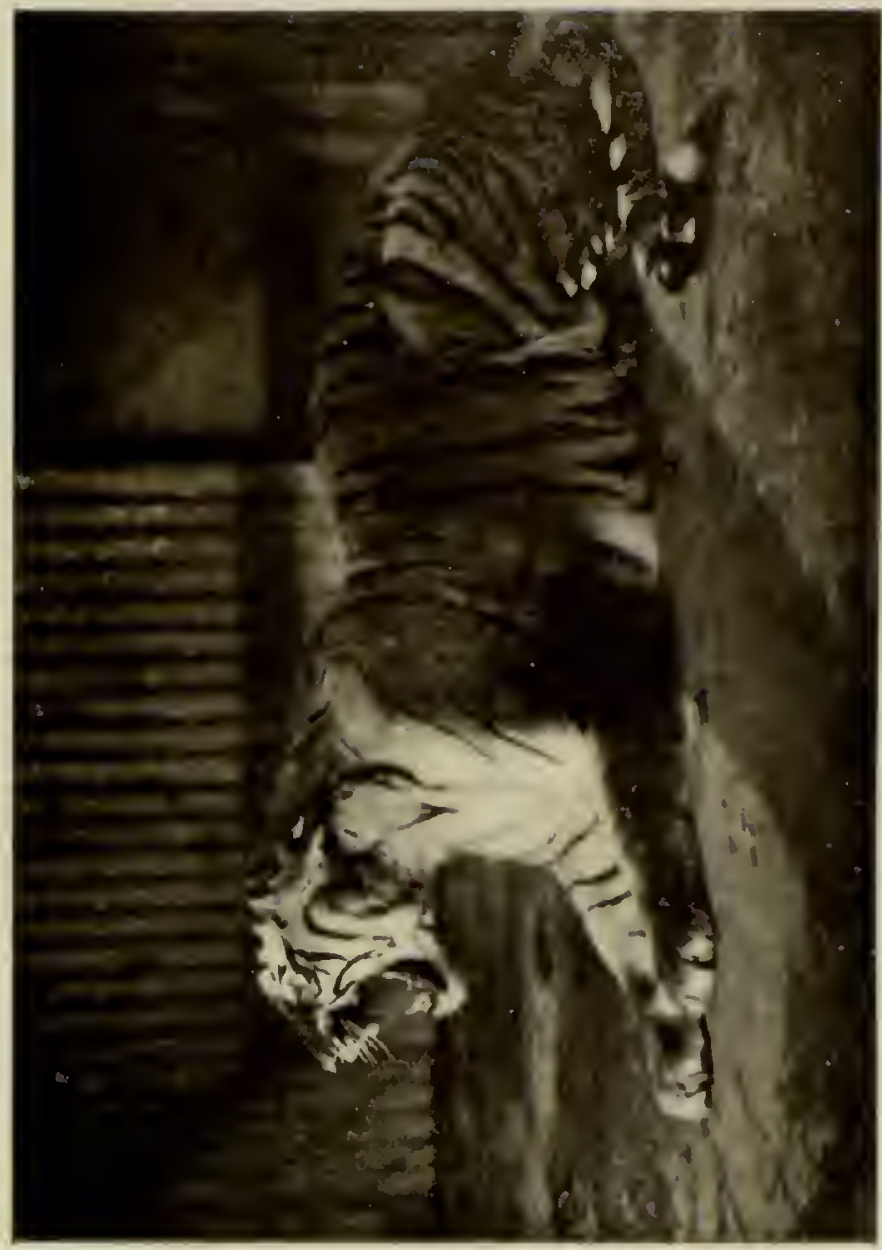

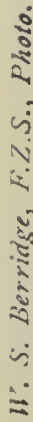

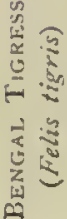




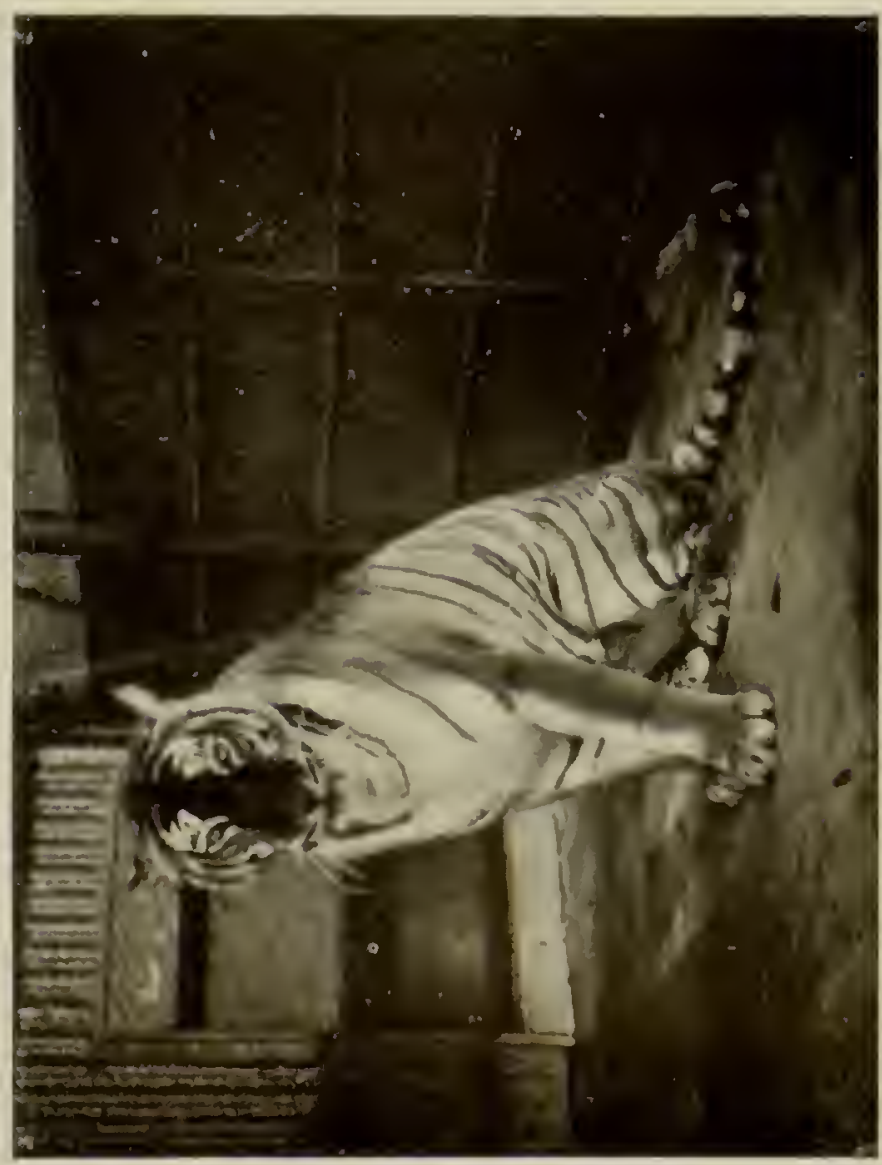

2ें

की 


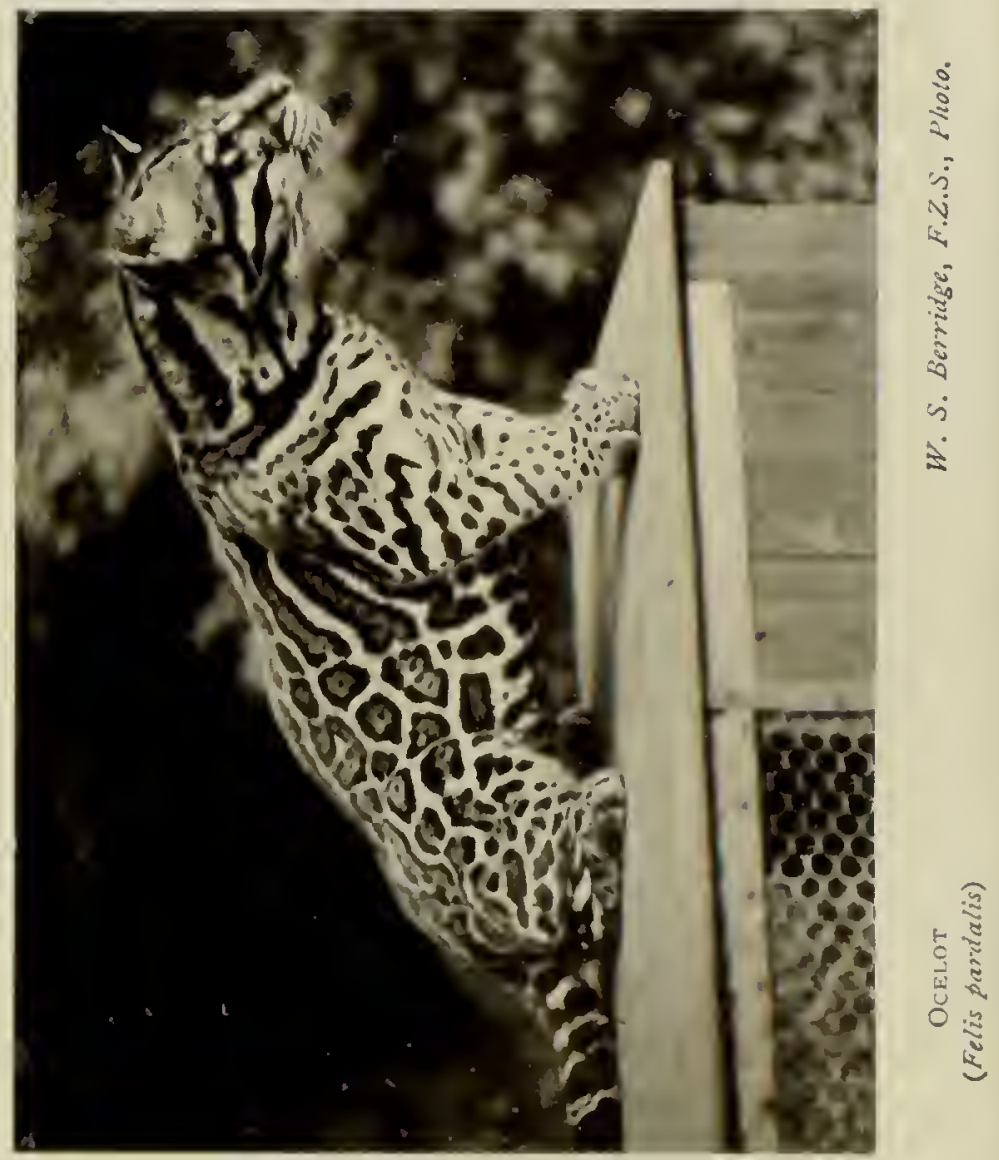




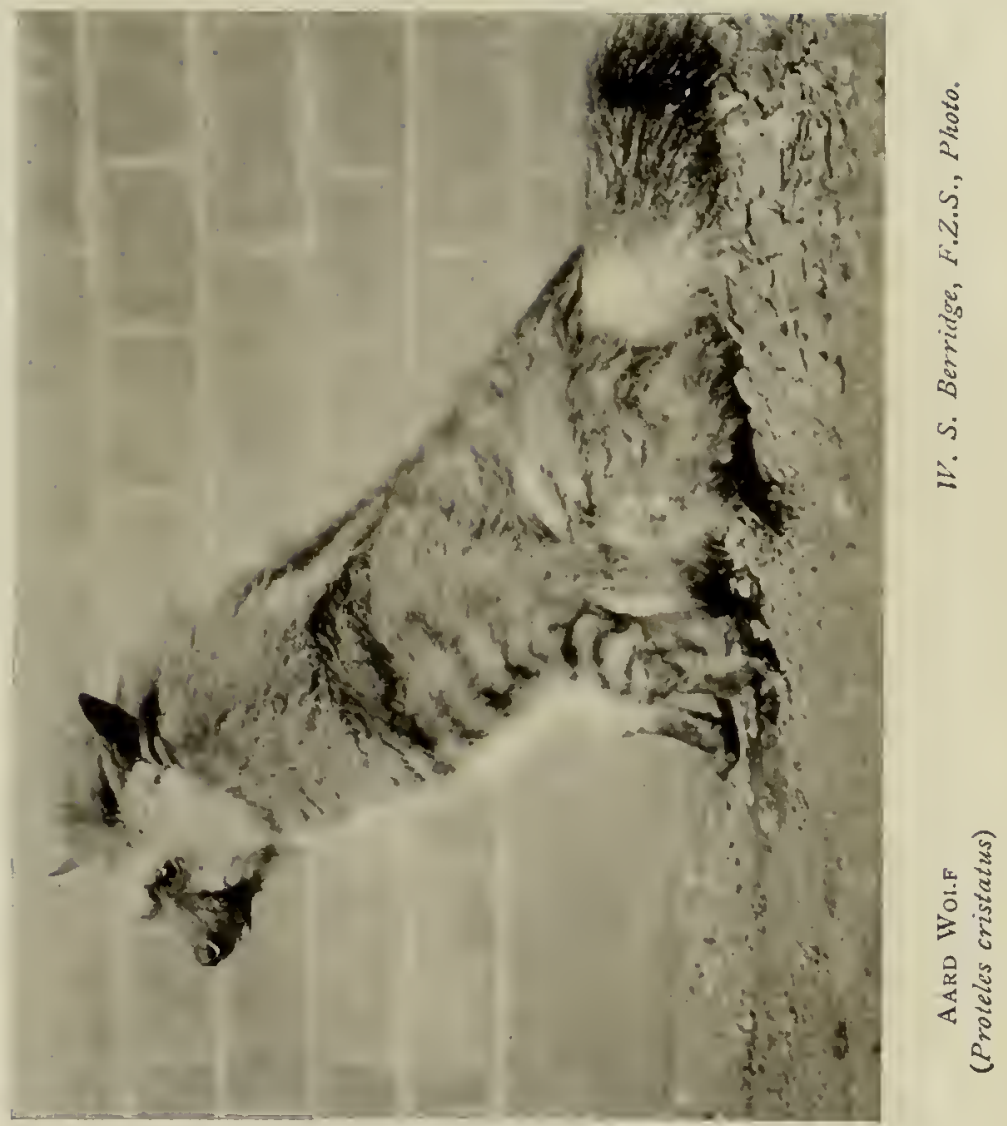




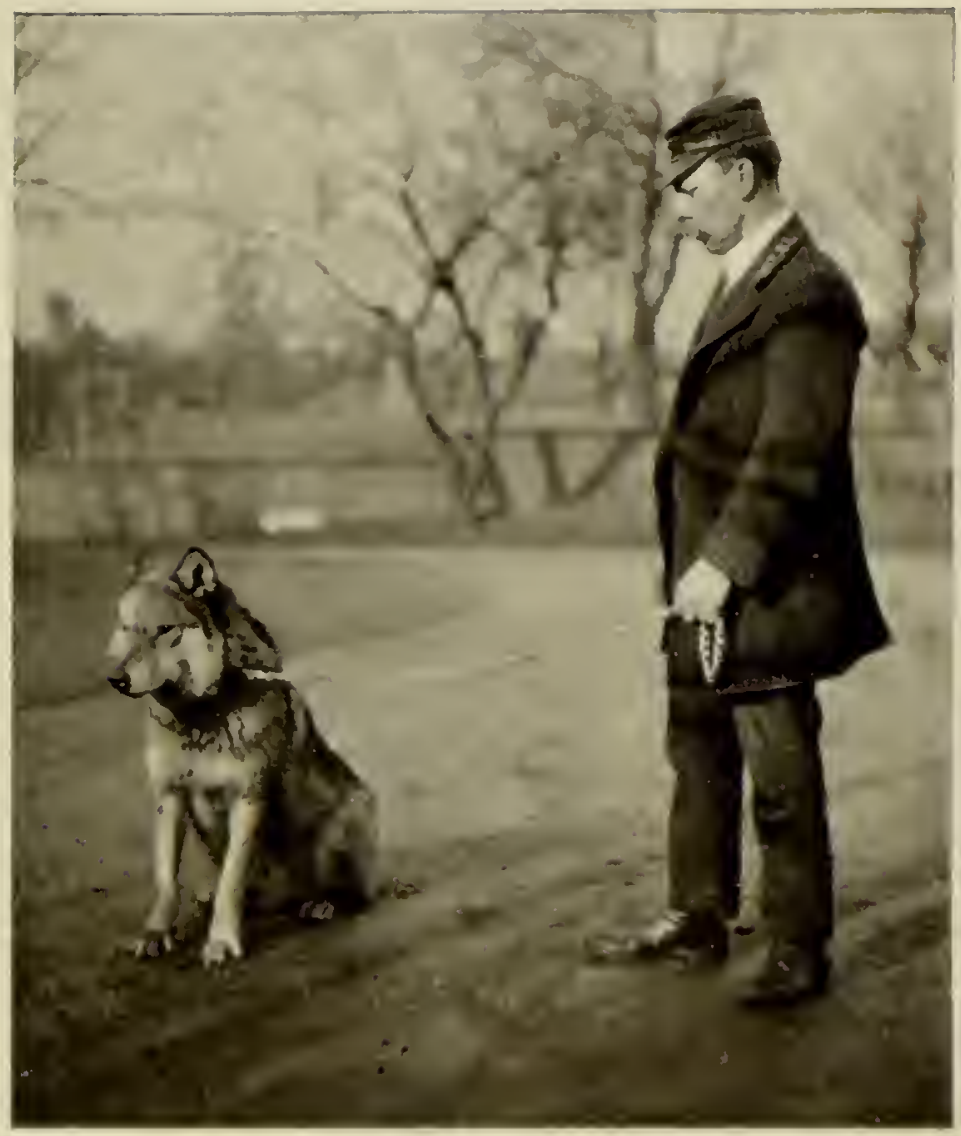

A PET TIMBER WIM.F (Canis occidentalis) 


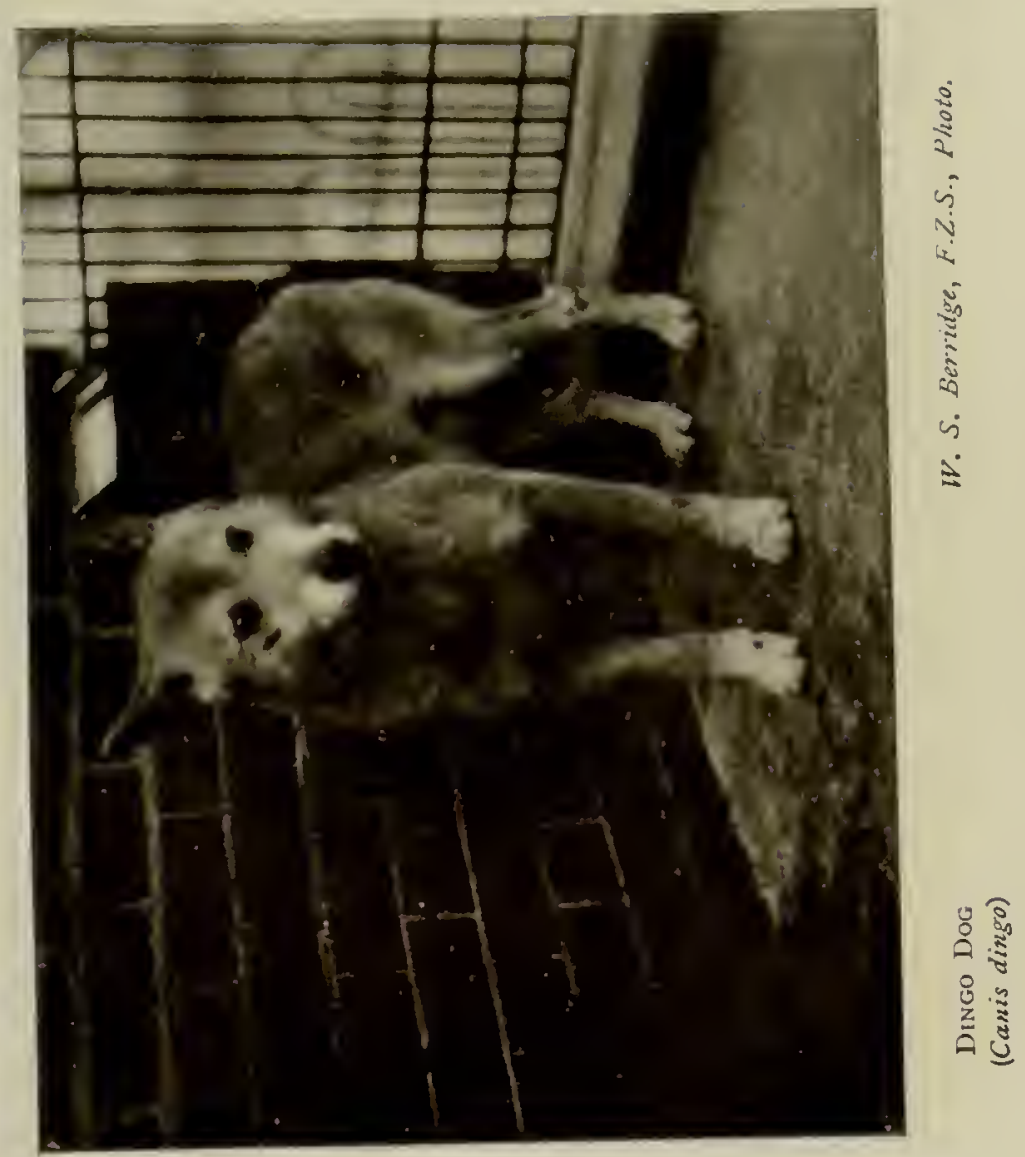




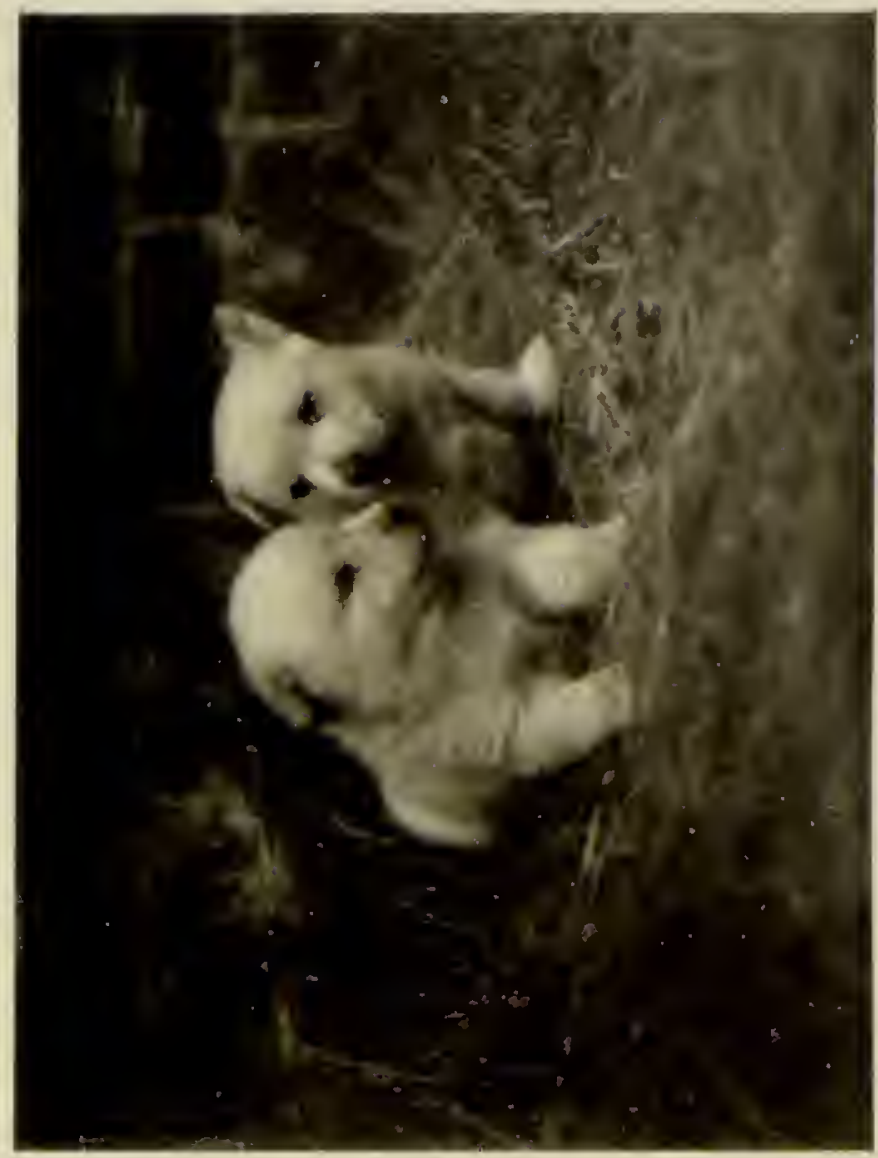

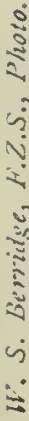

$\frac{3}{0}$

$\frac{3}{3}$

0

n

A

0
0
7
0 


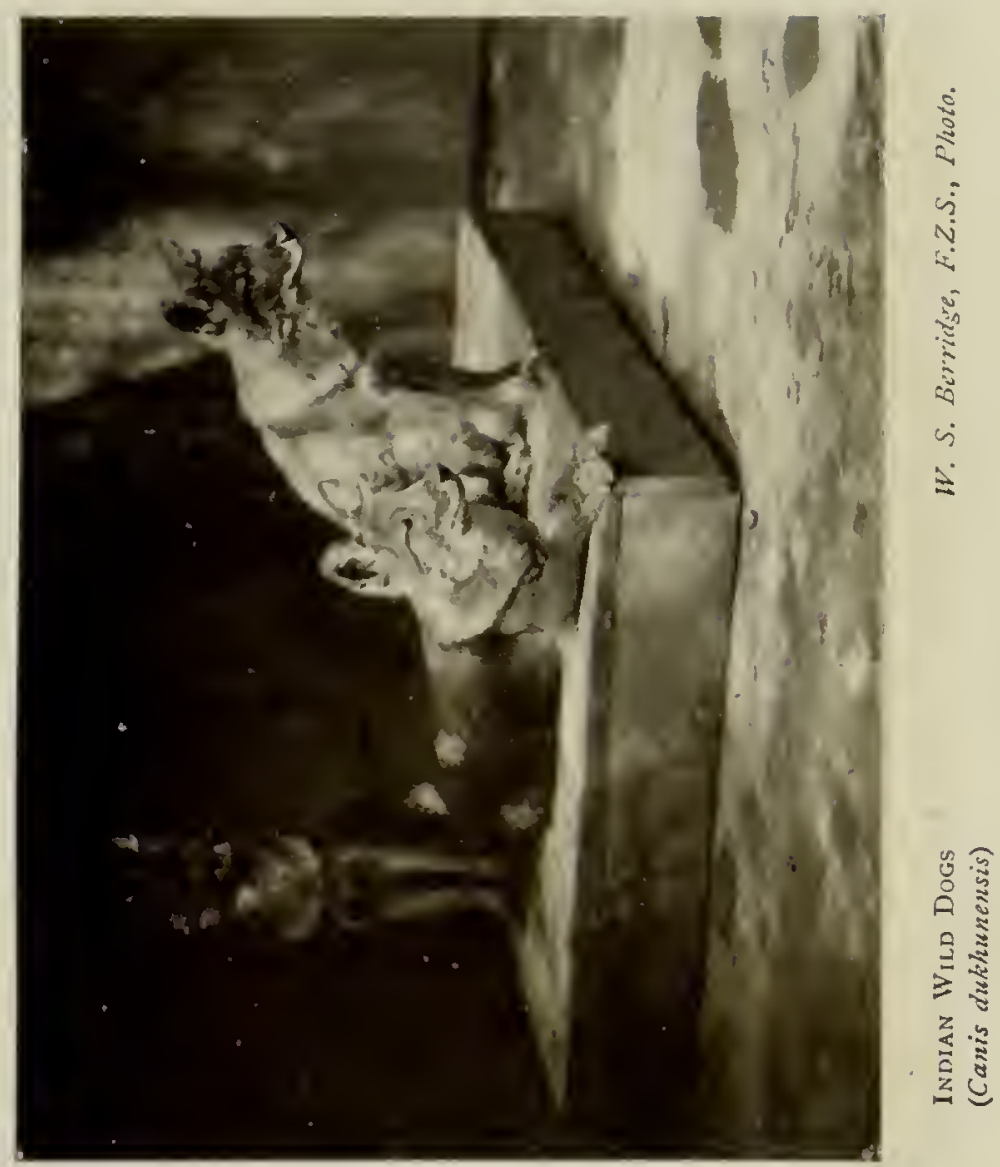




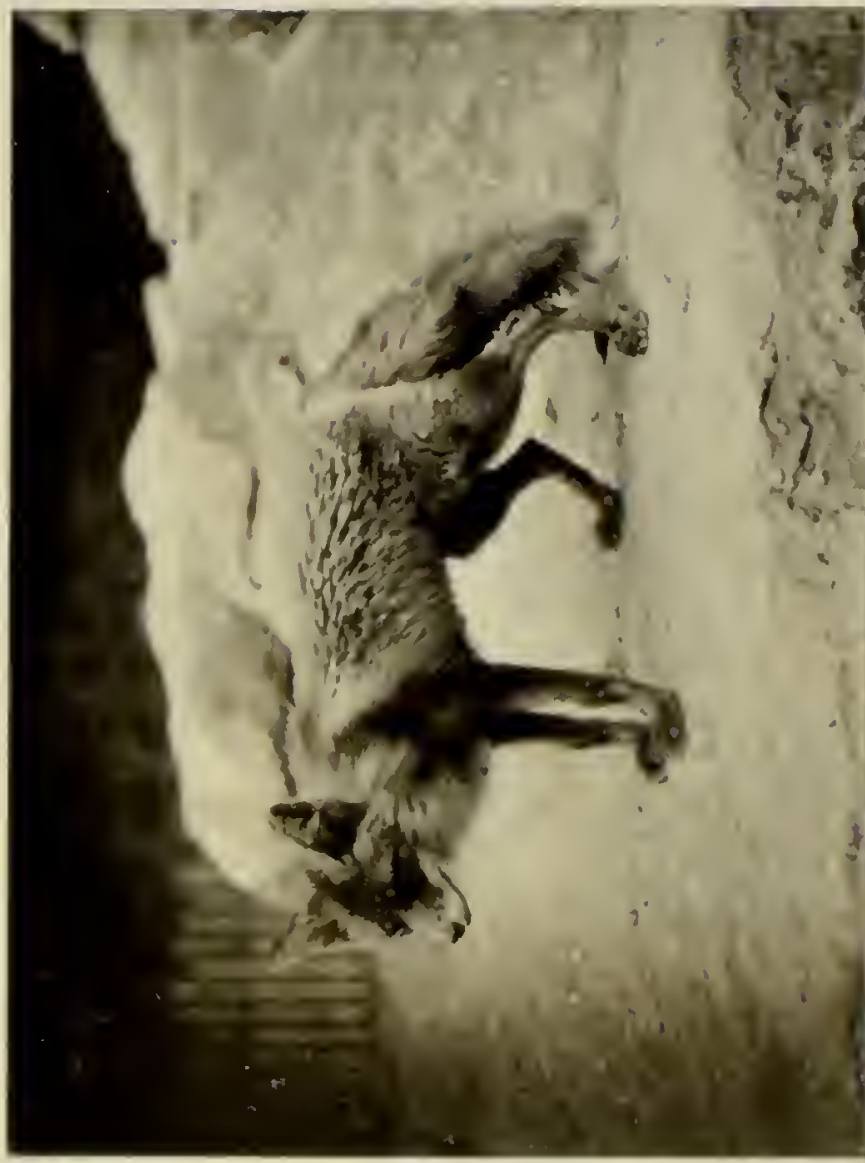

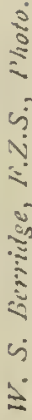

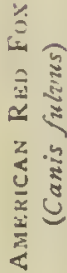




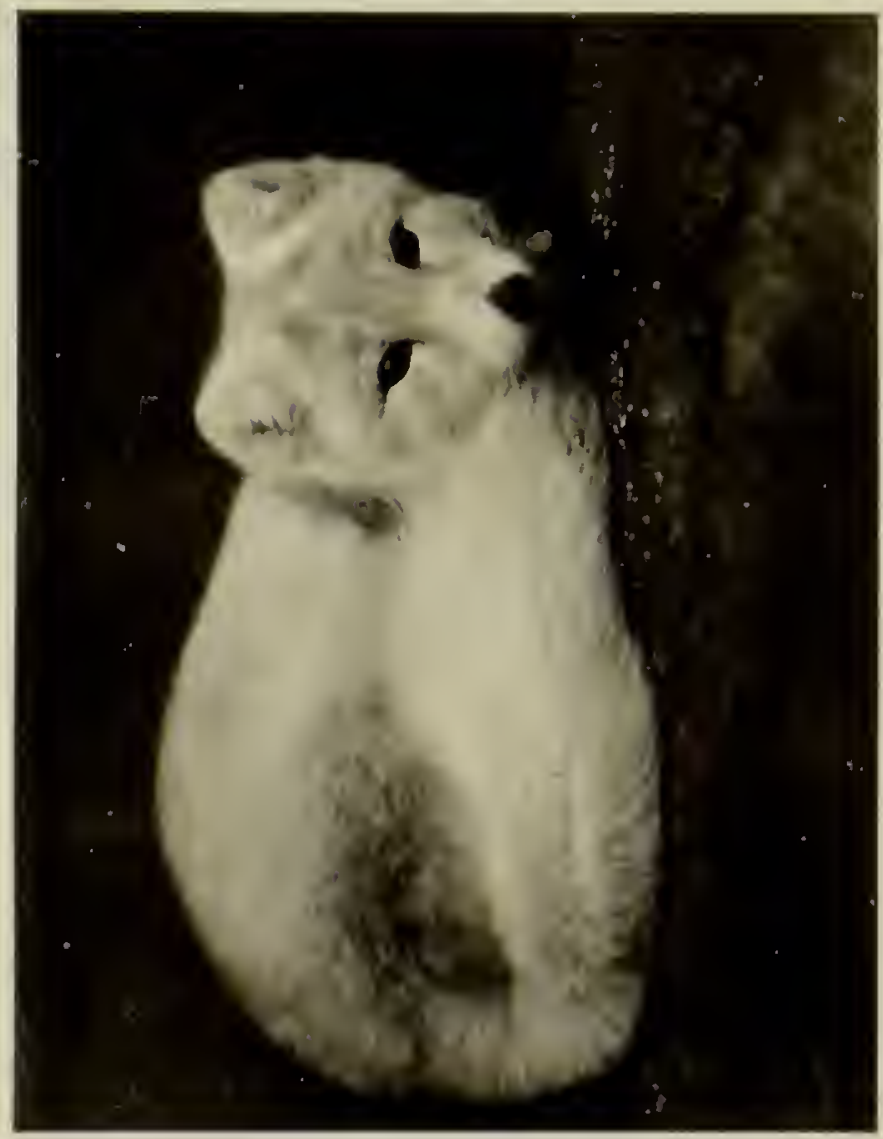

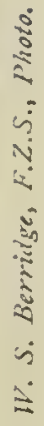

5

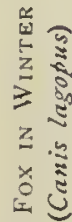

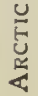




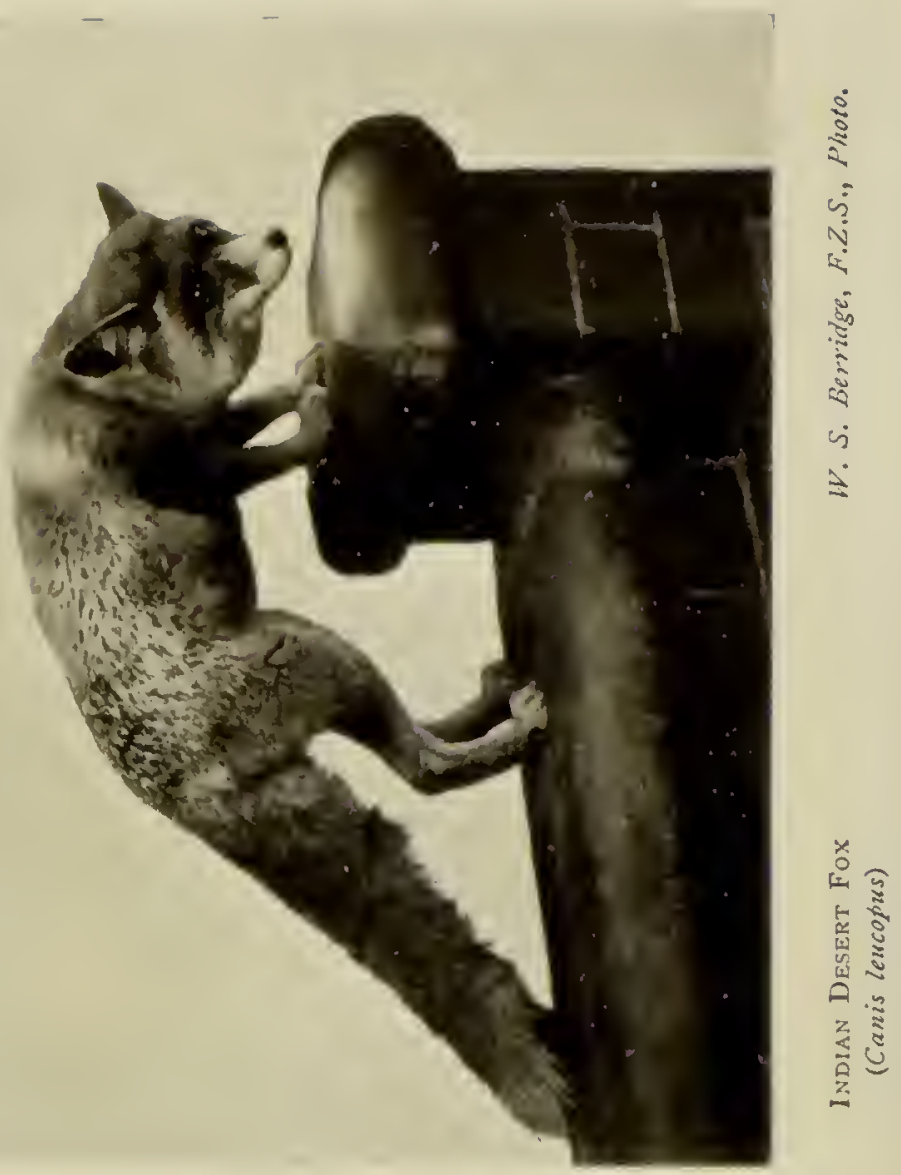




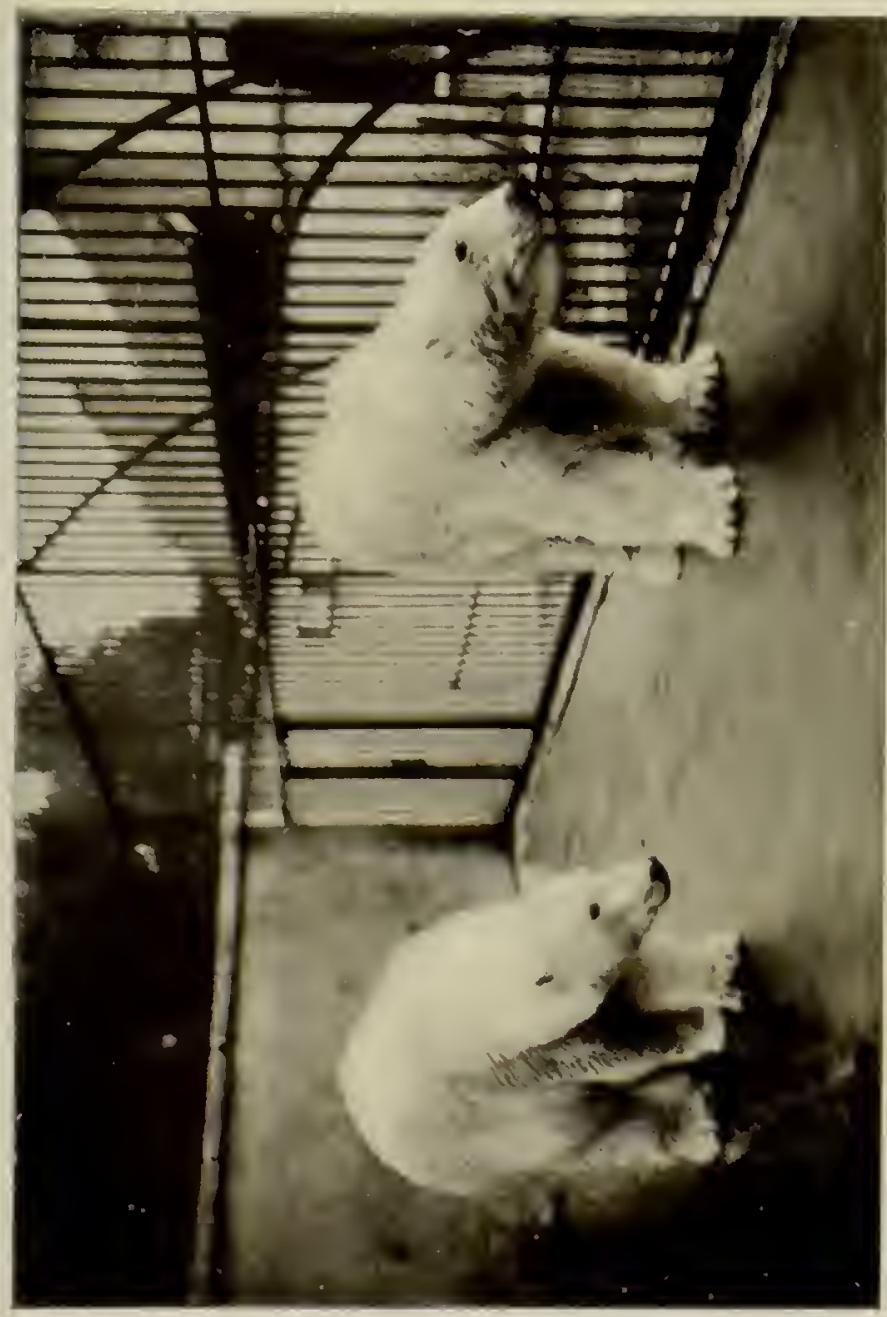

20

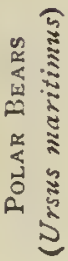




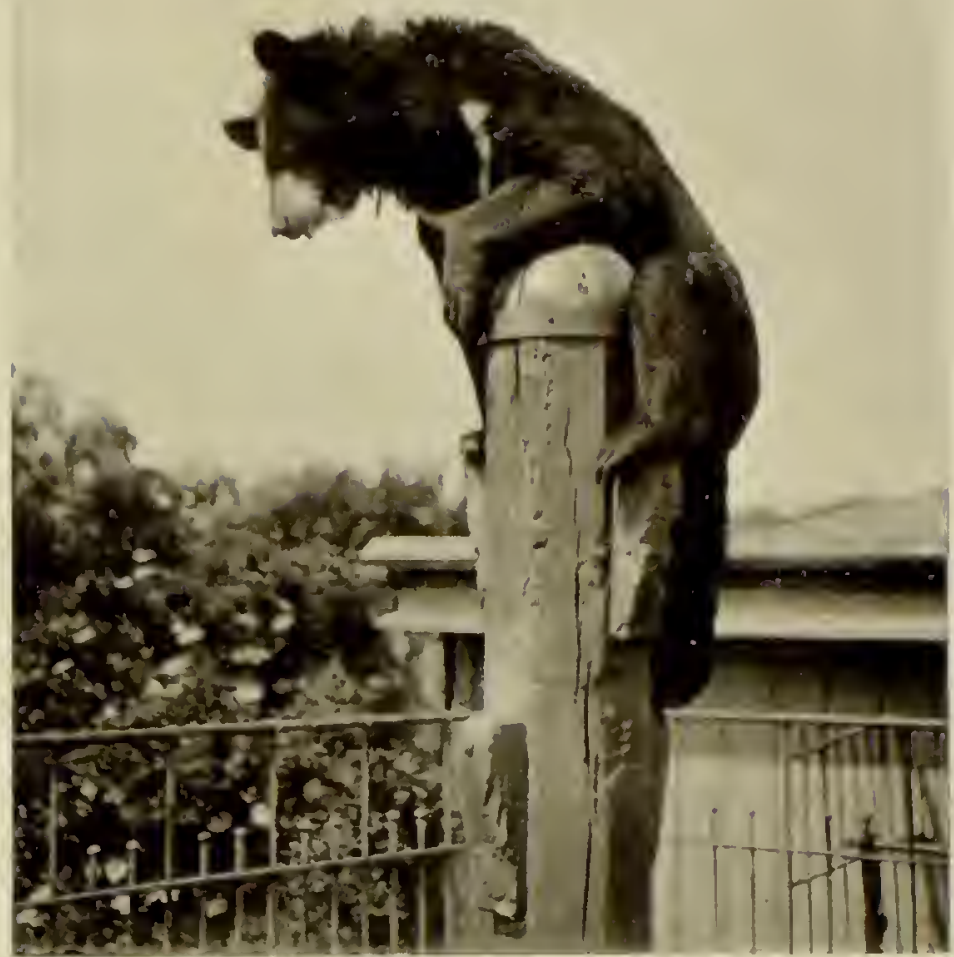

Himalayan Blach Bear IV. S. Birridge, FiZ.S., Hhots. (Ursus tibitanus) 


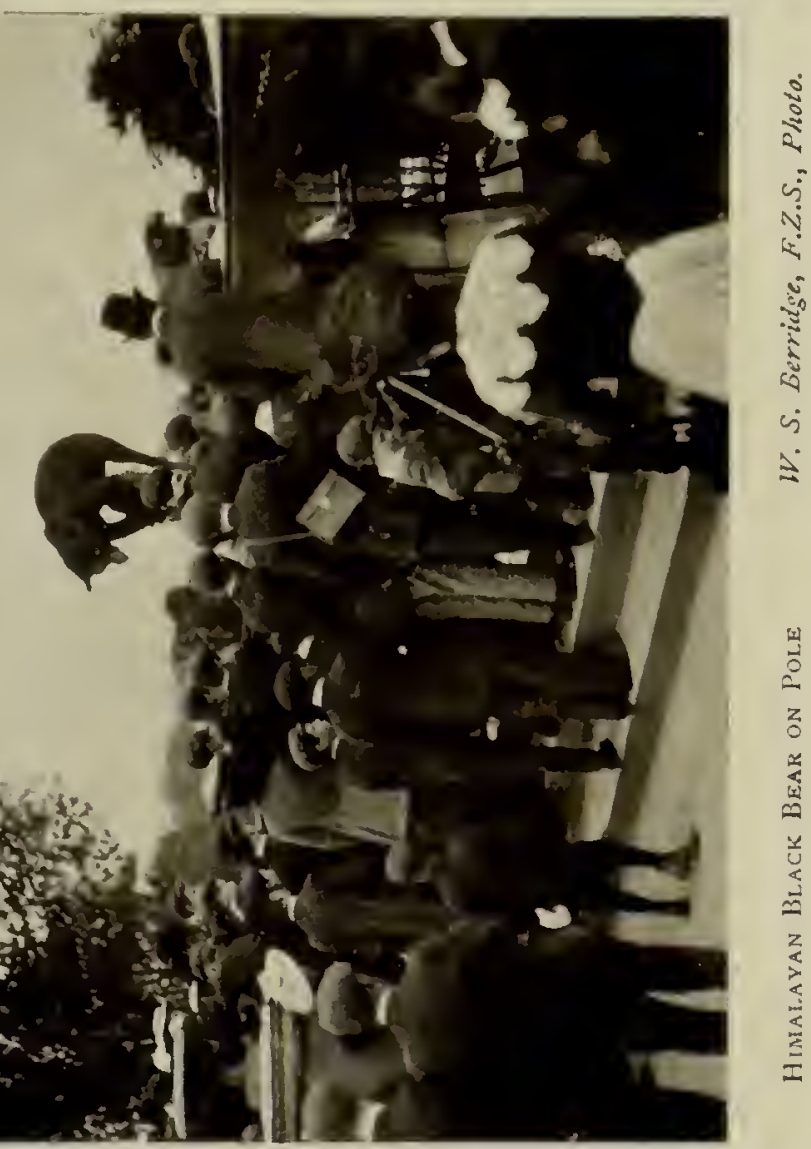




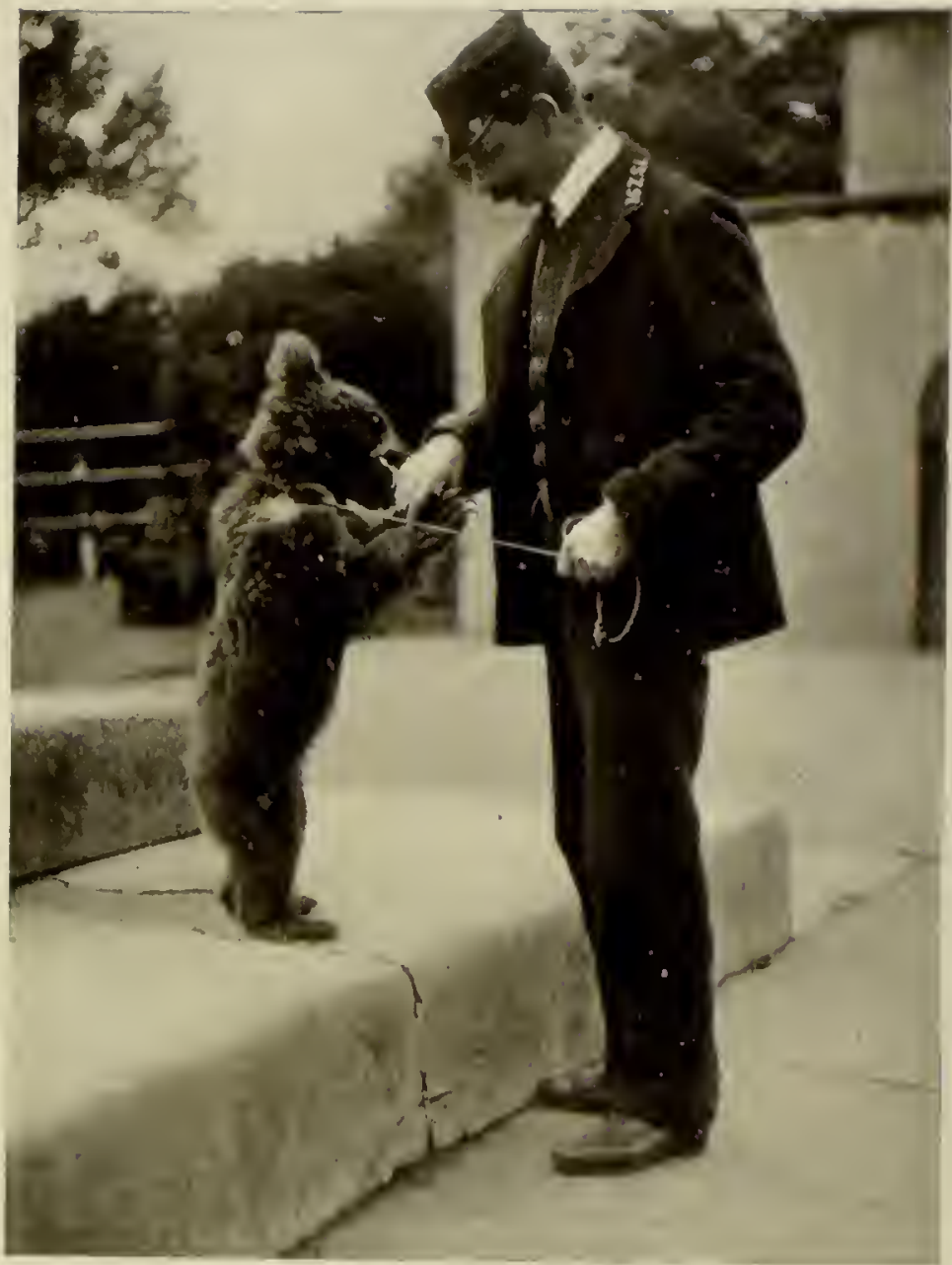

Young SVRIAN BEAR

(Ursus syriacus)

W. S. Berridge, li.Z.S., Ploto. 


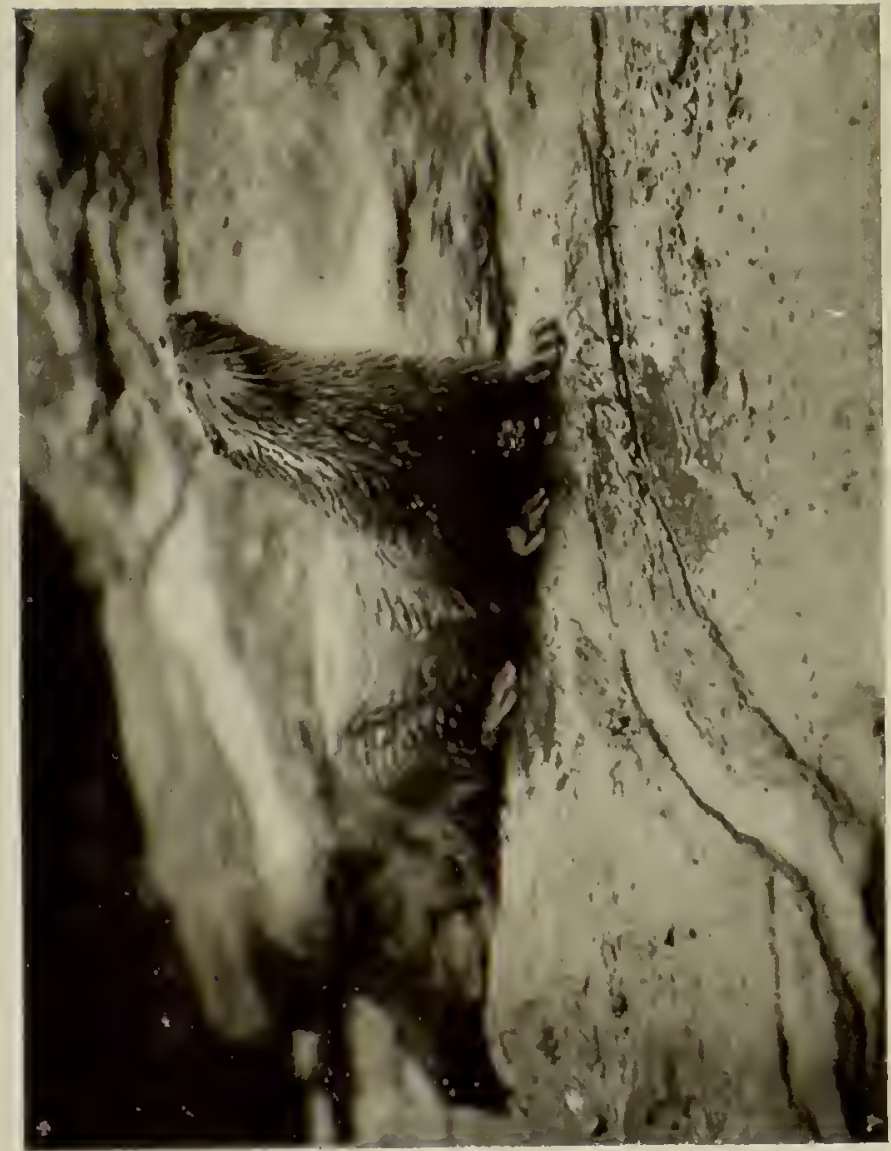

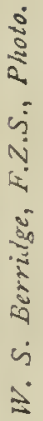

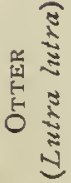




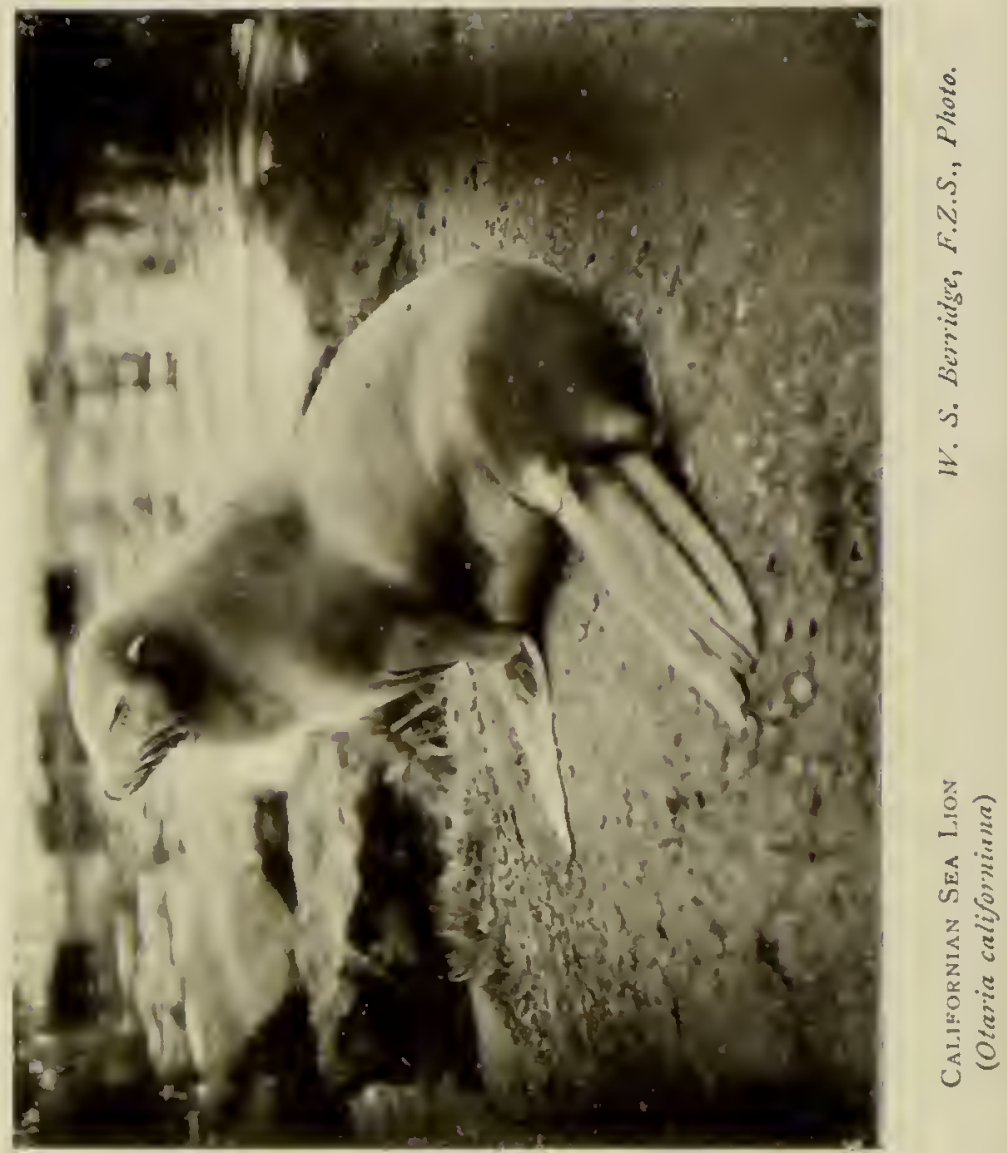




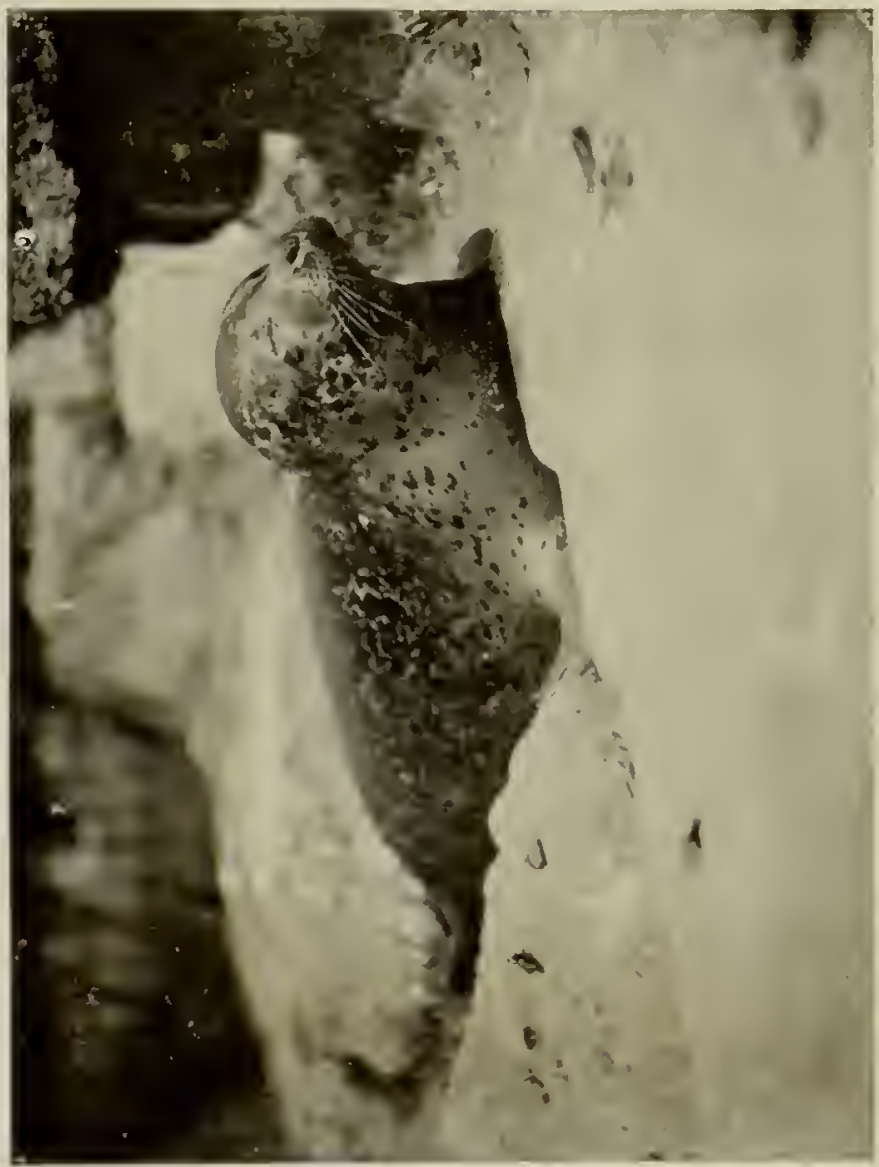

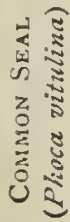




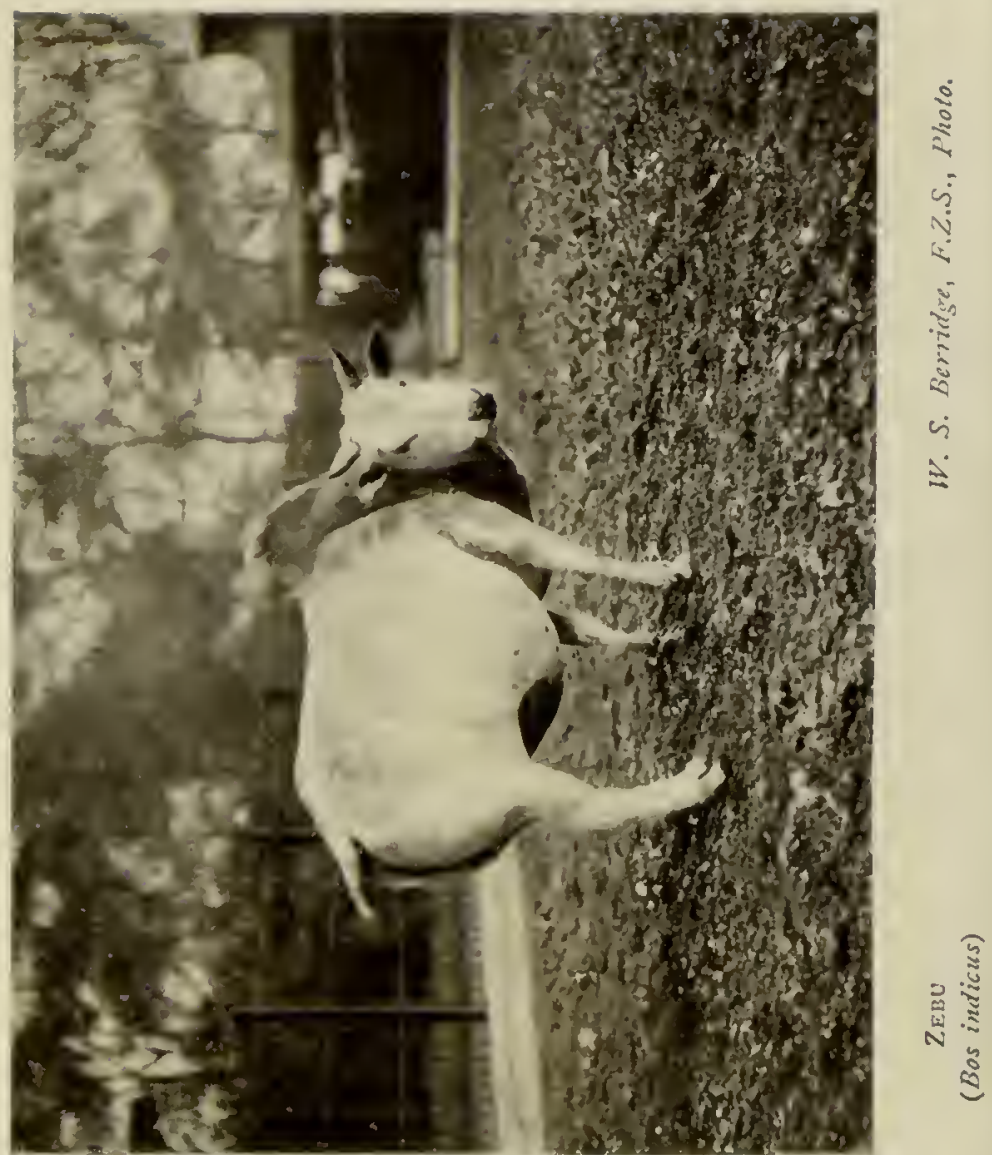




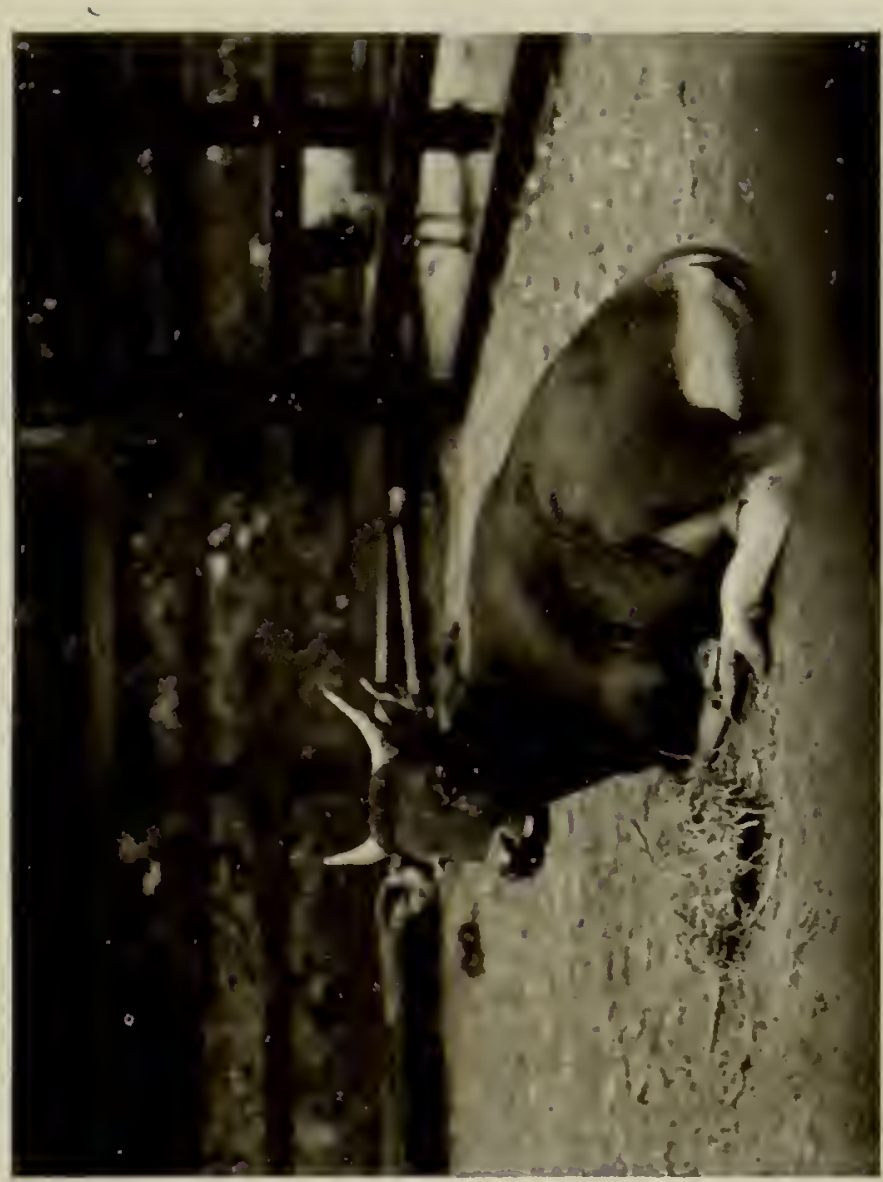

aे

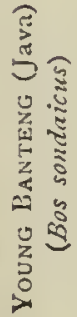




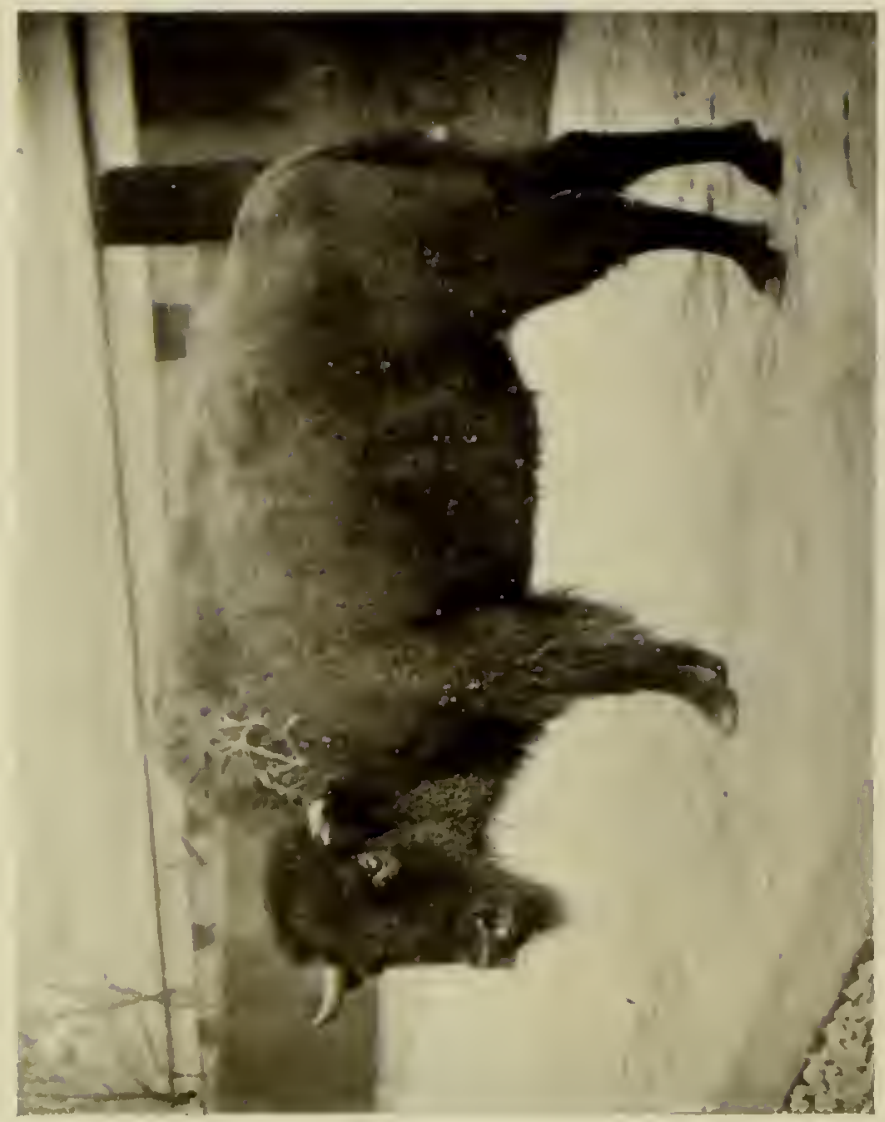

20

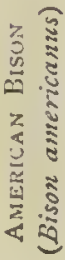




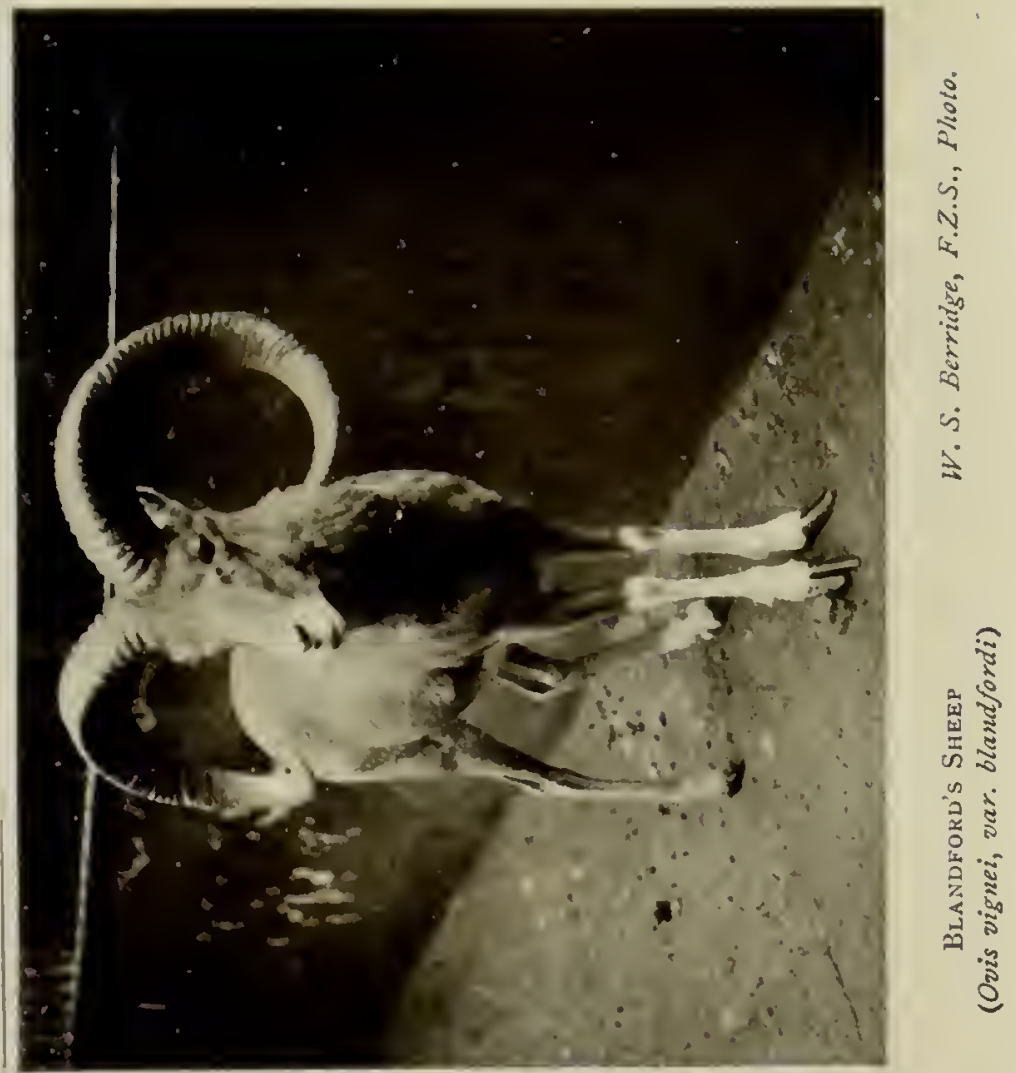




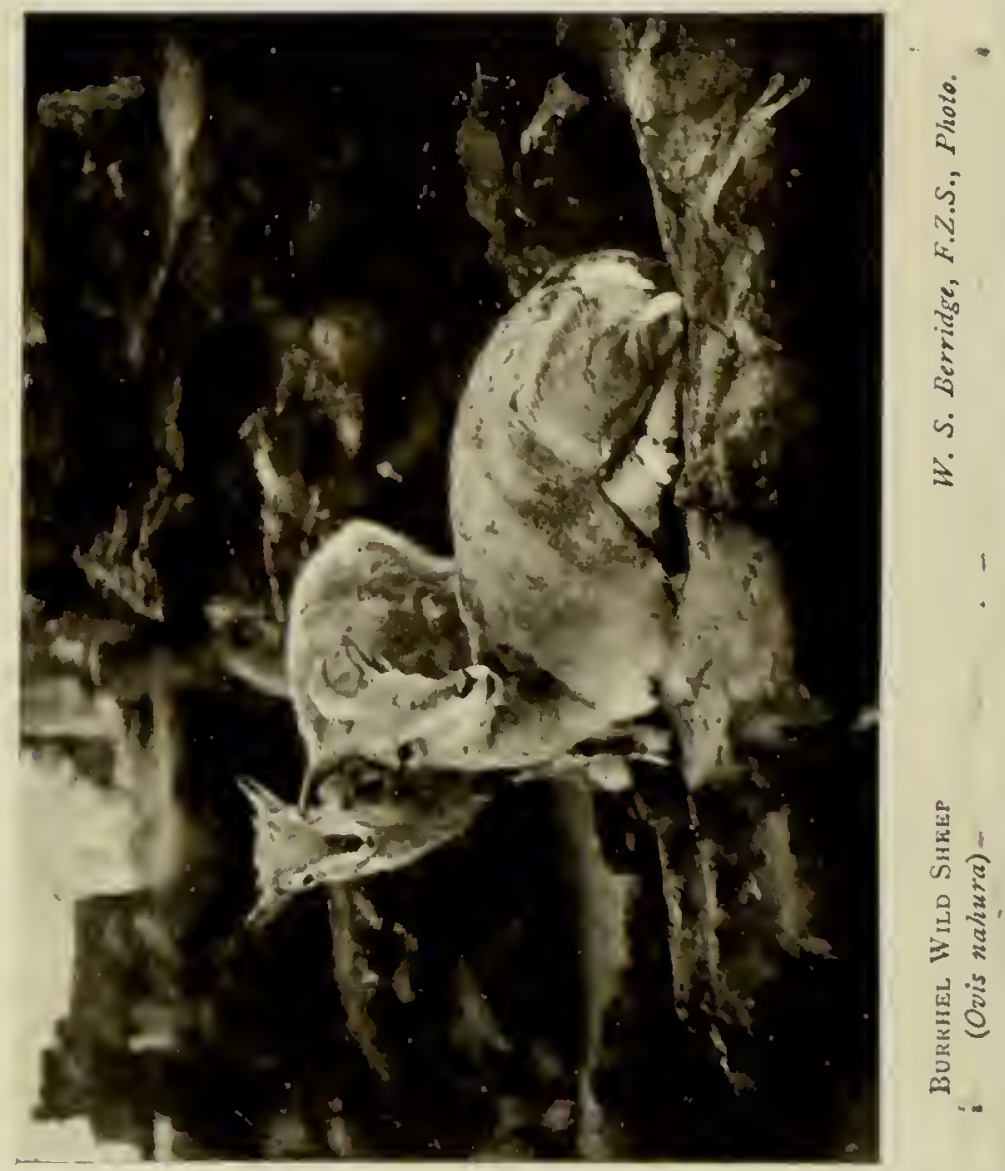




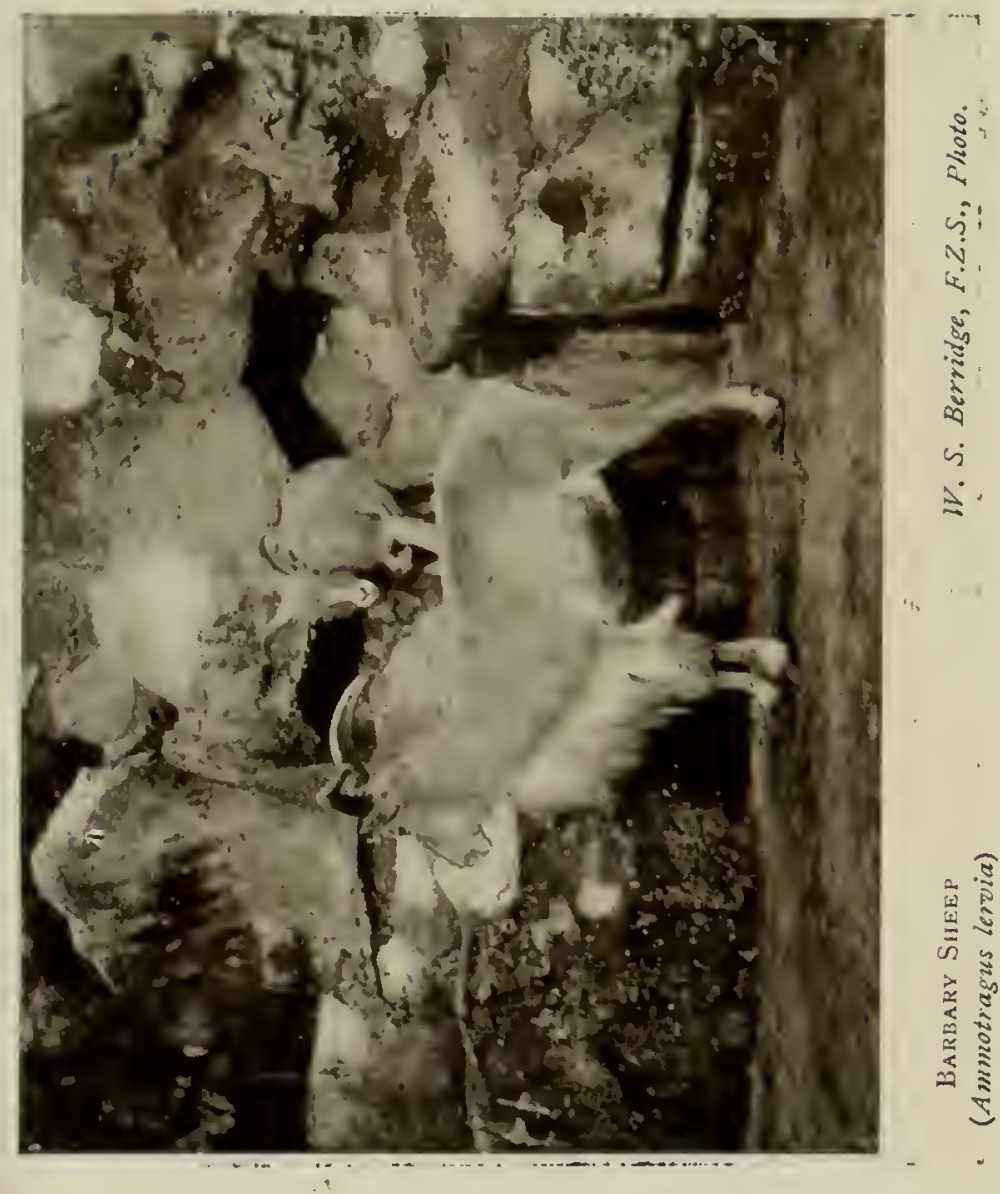



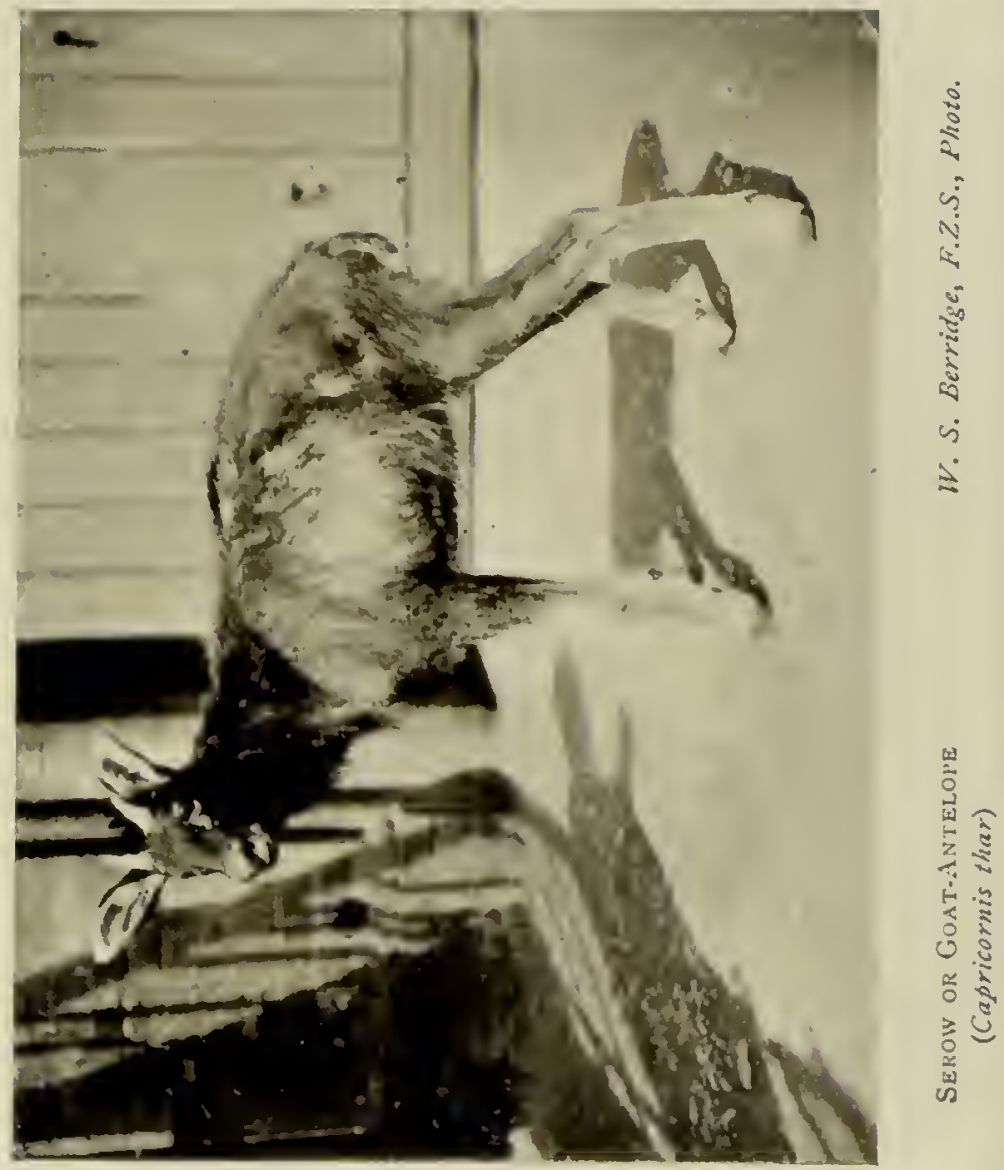


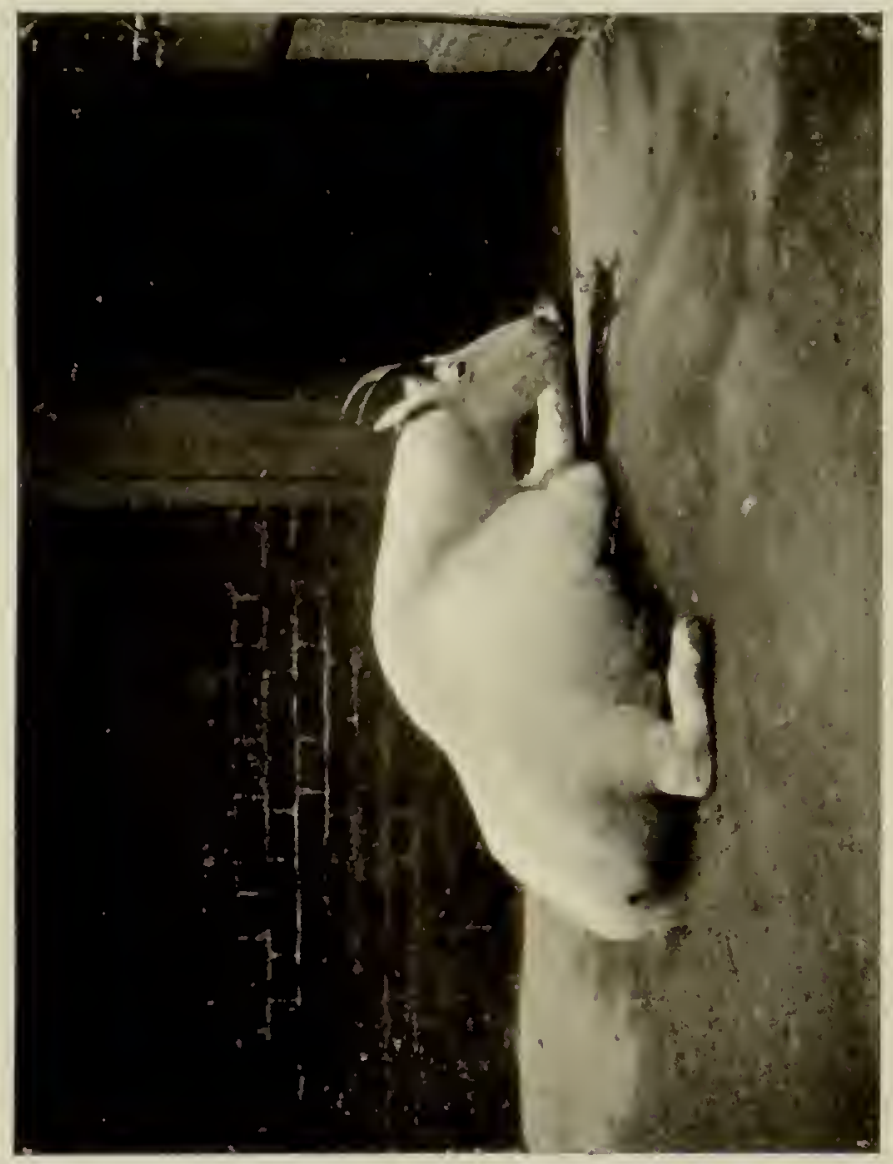

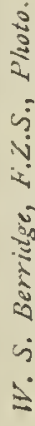

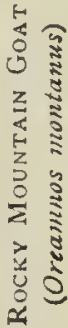




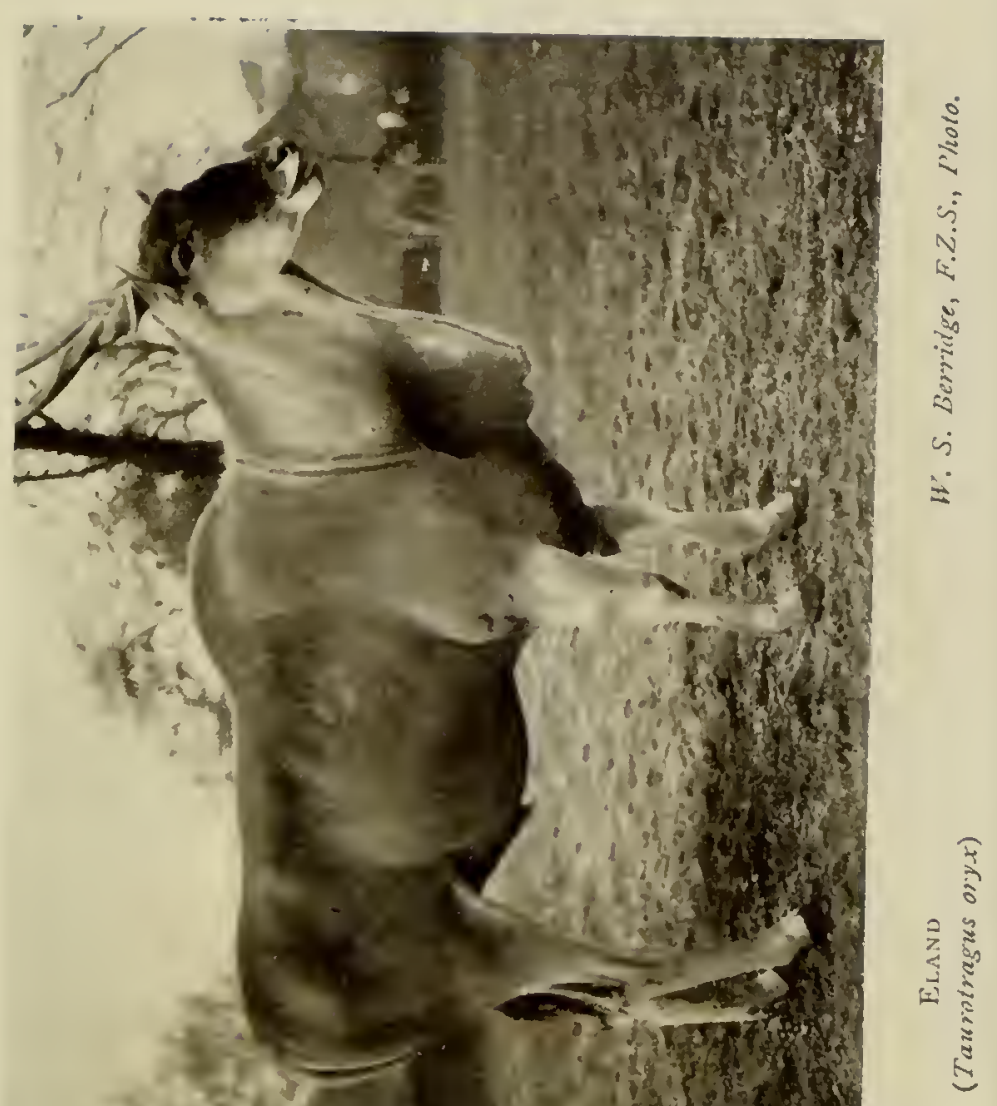




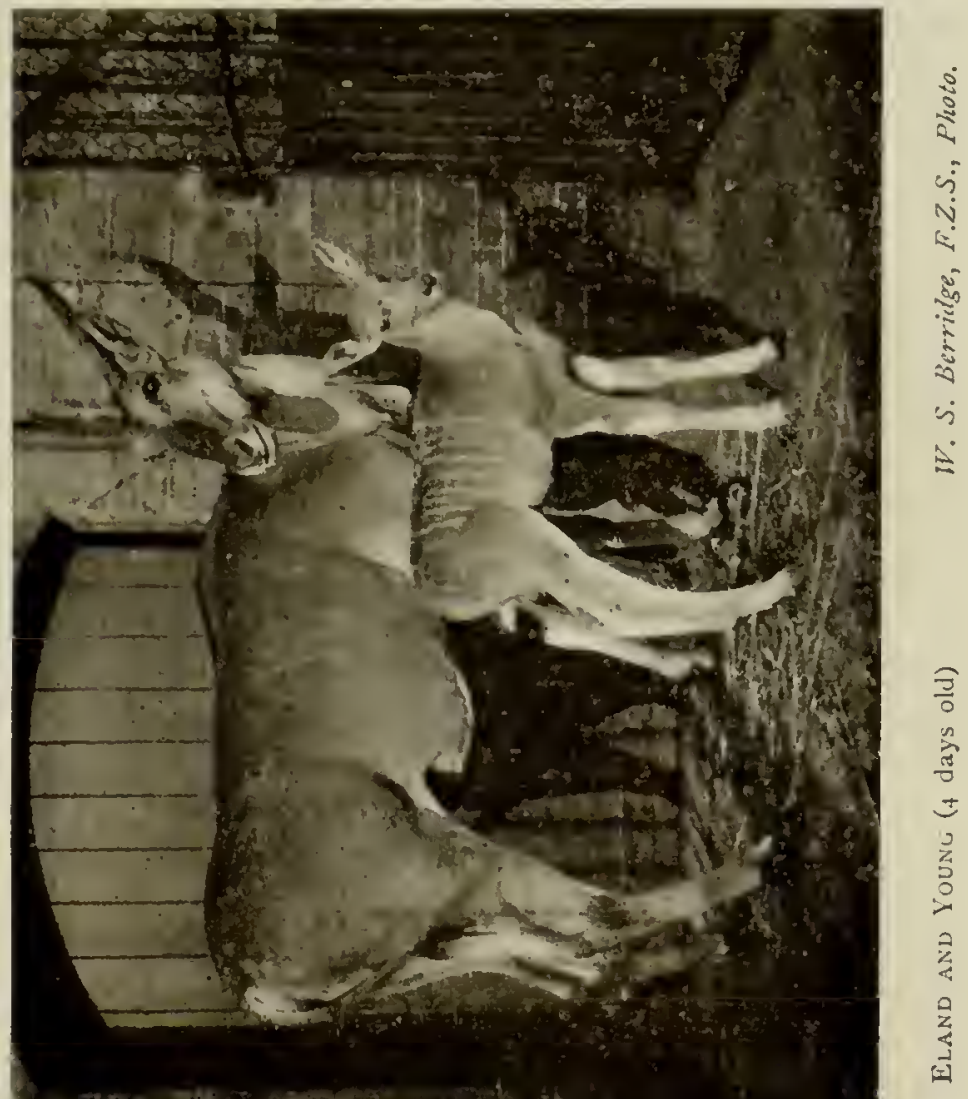

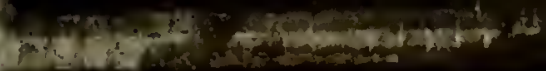




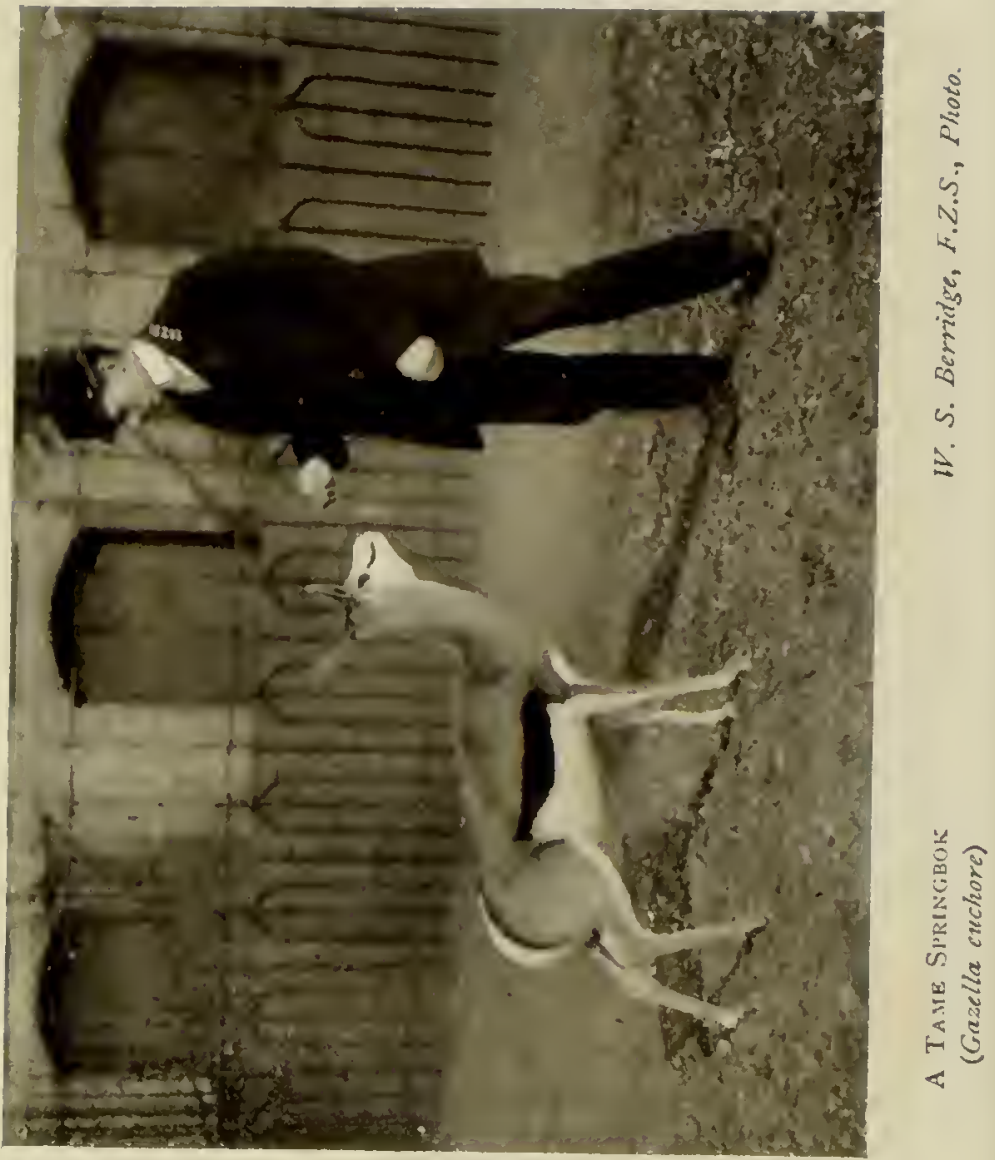




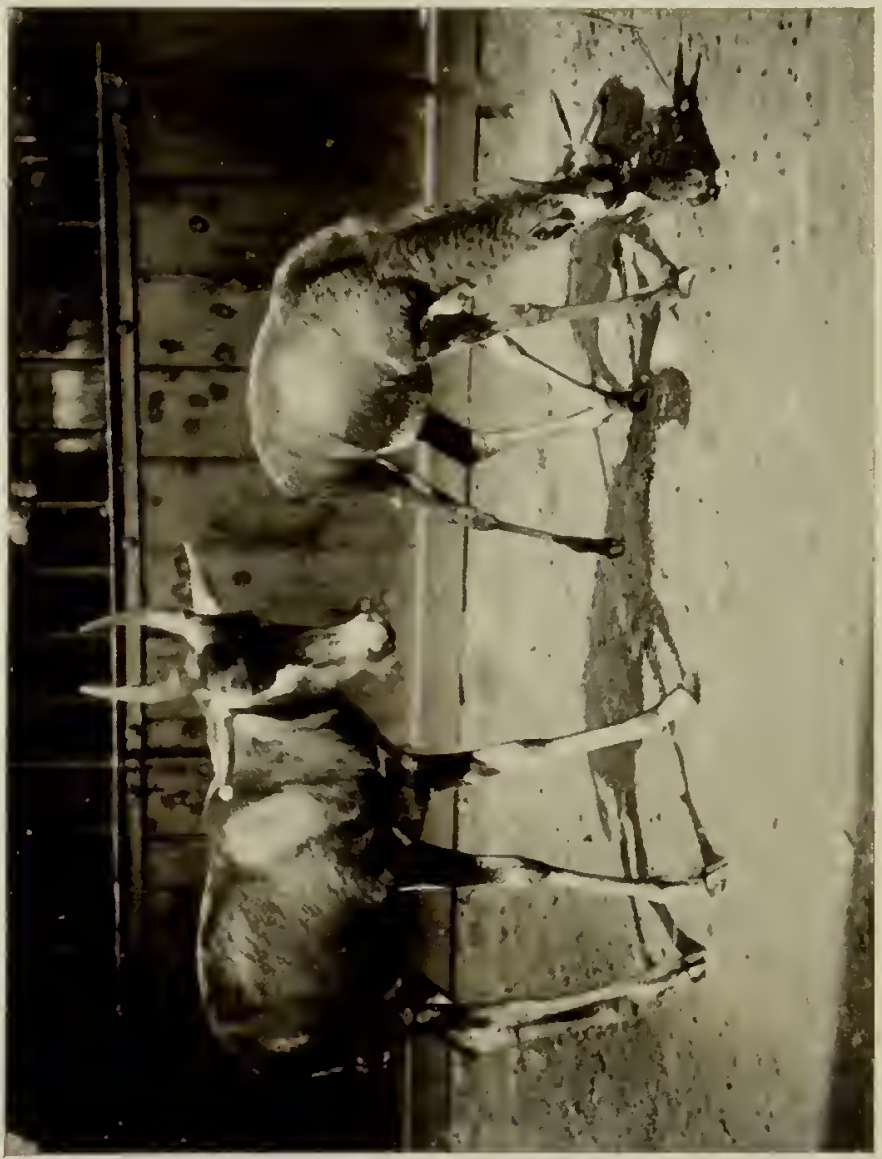

a

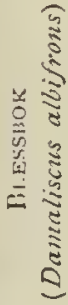




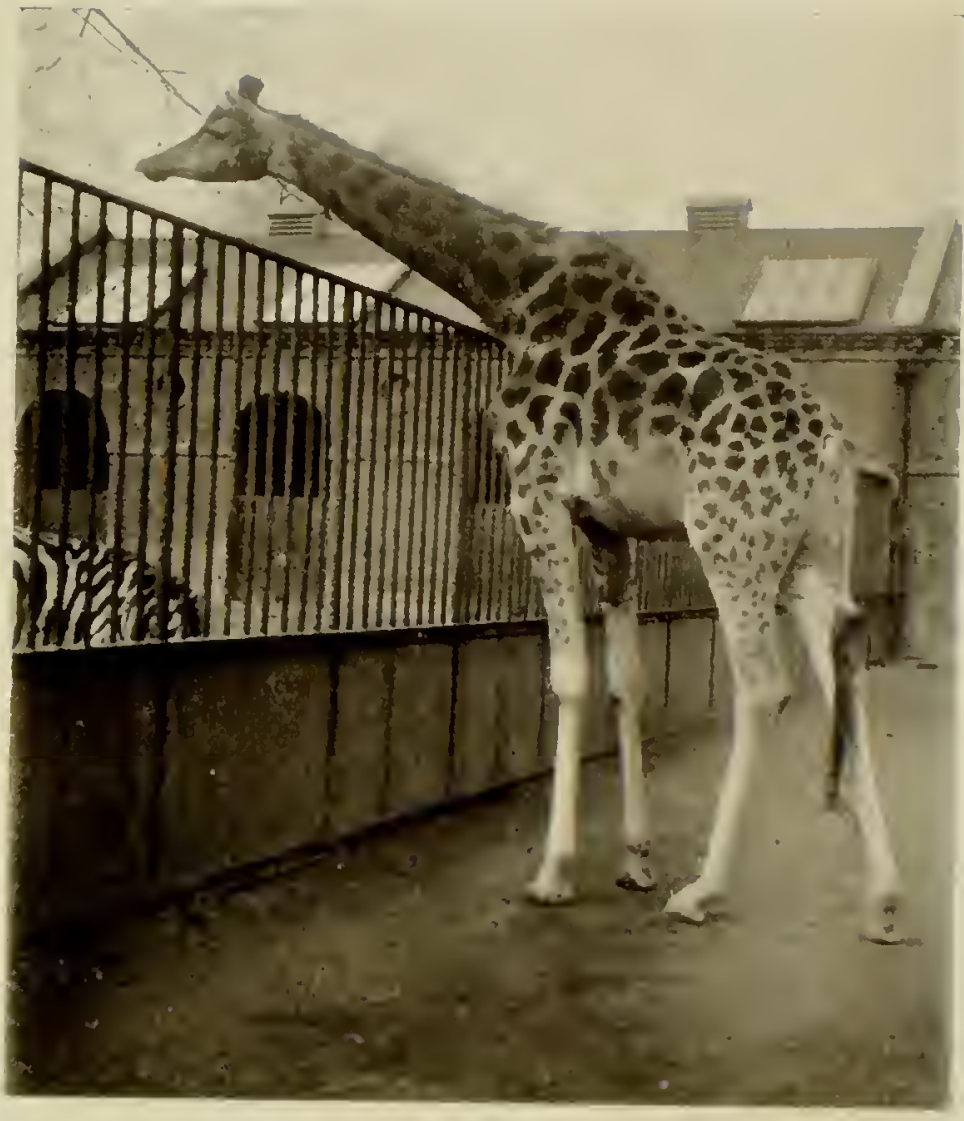

Girafre

(Giraffa camelopardalis)

W. S. Berritge, F.Z.S., Ploto. 


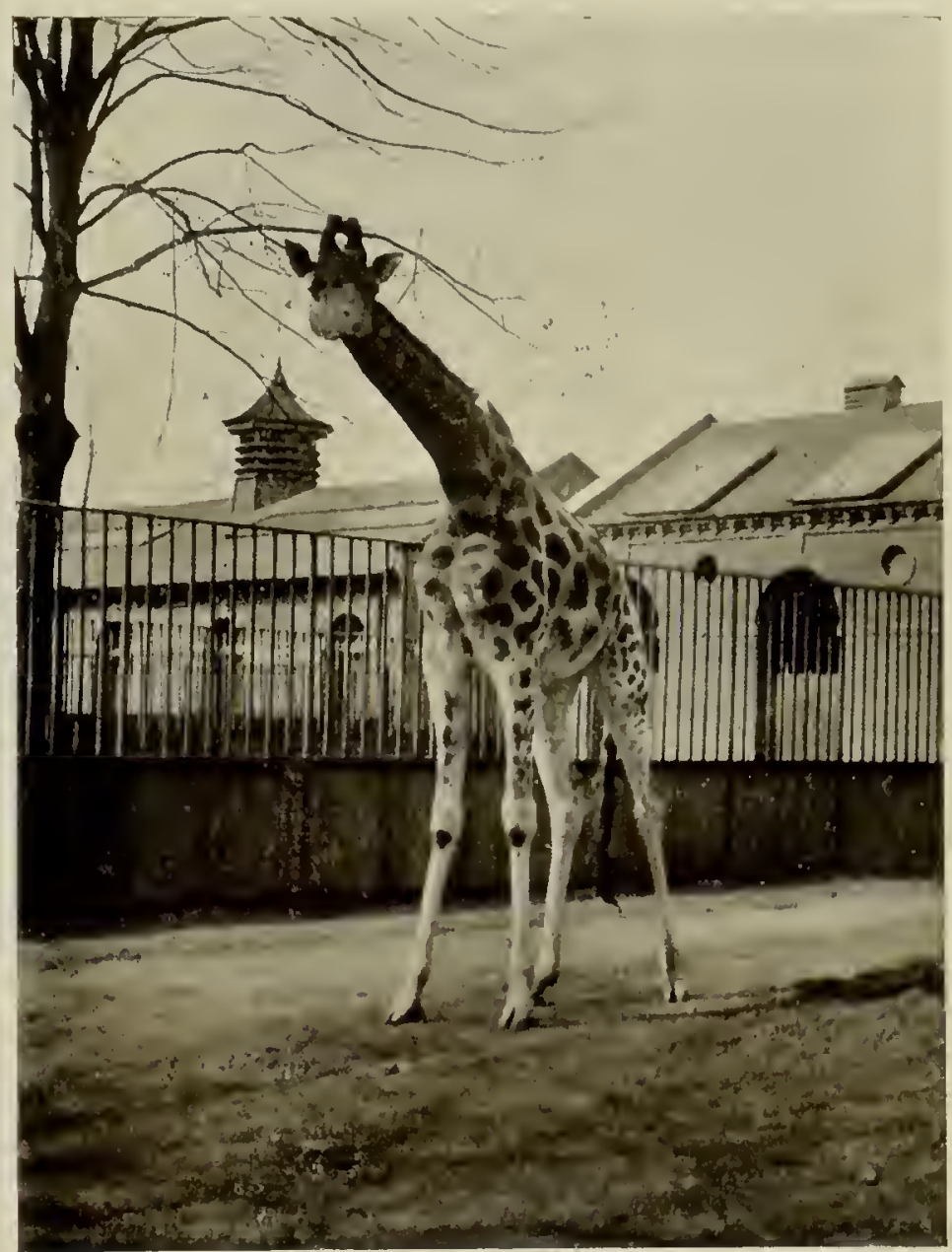

GIKAFFE

U'. S. Berritige, F.Z.S., Ploto. 


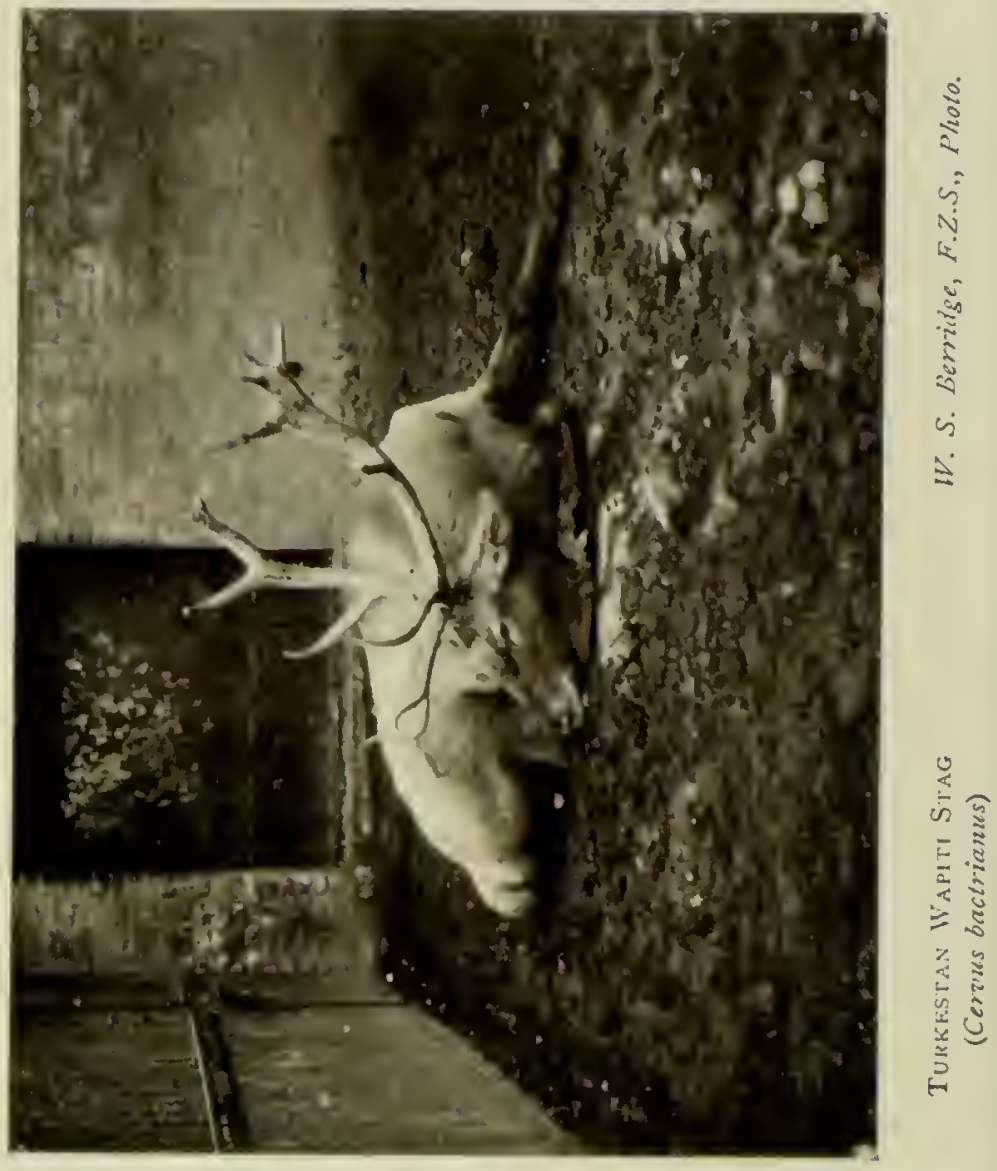




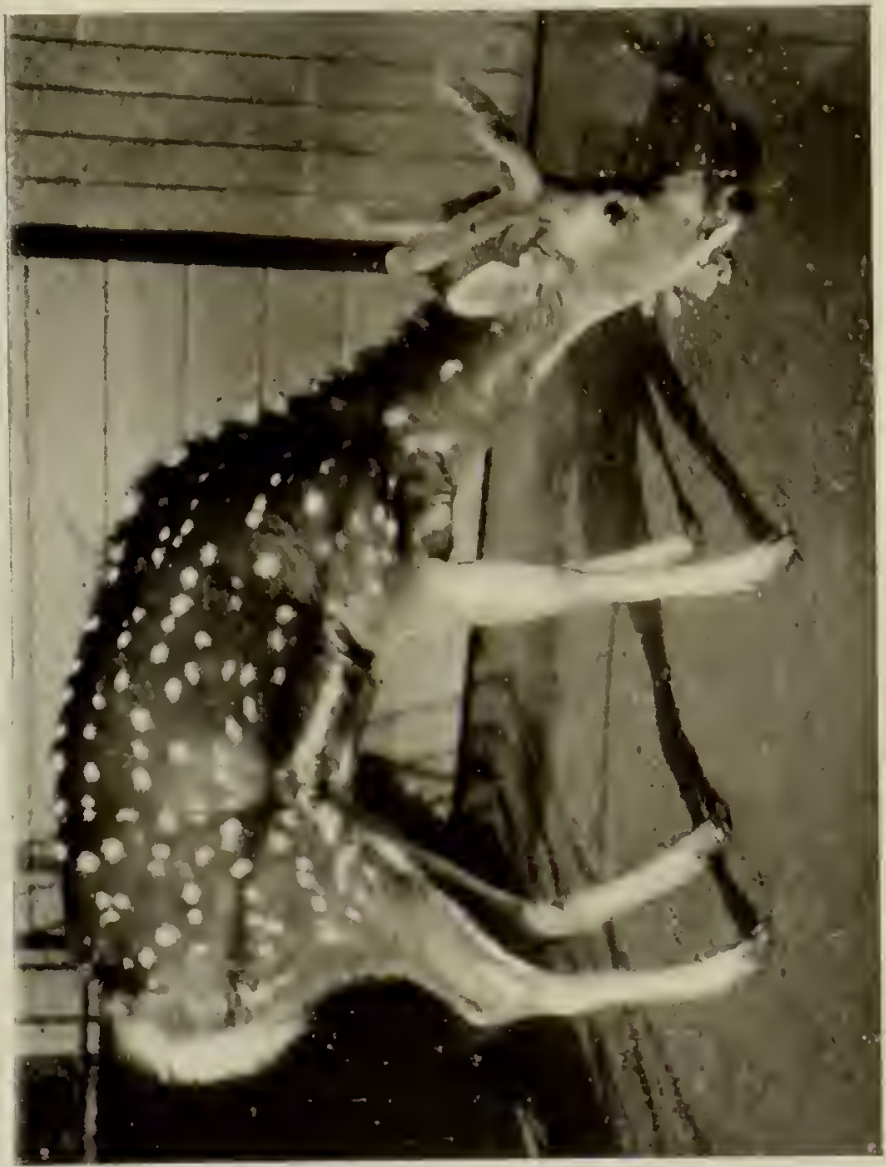

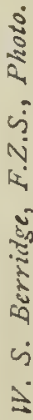

 


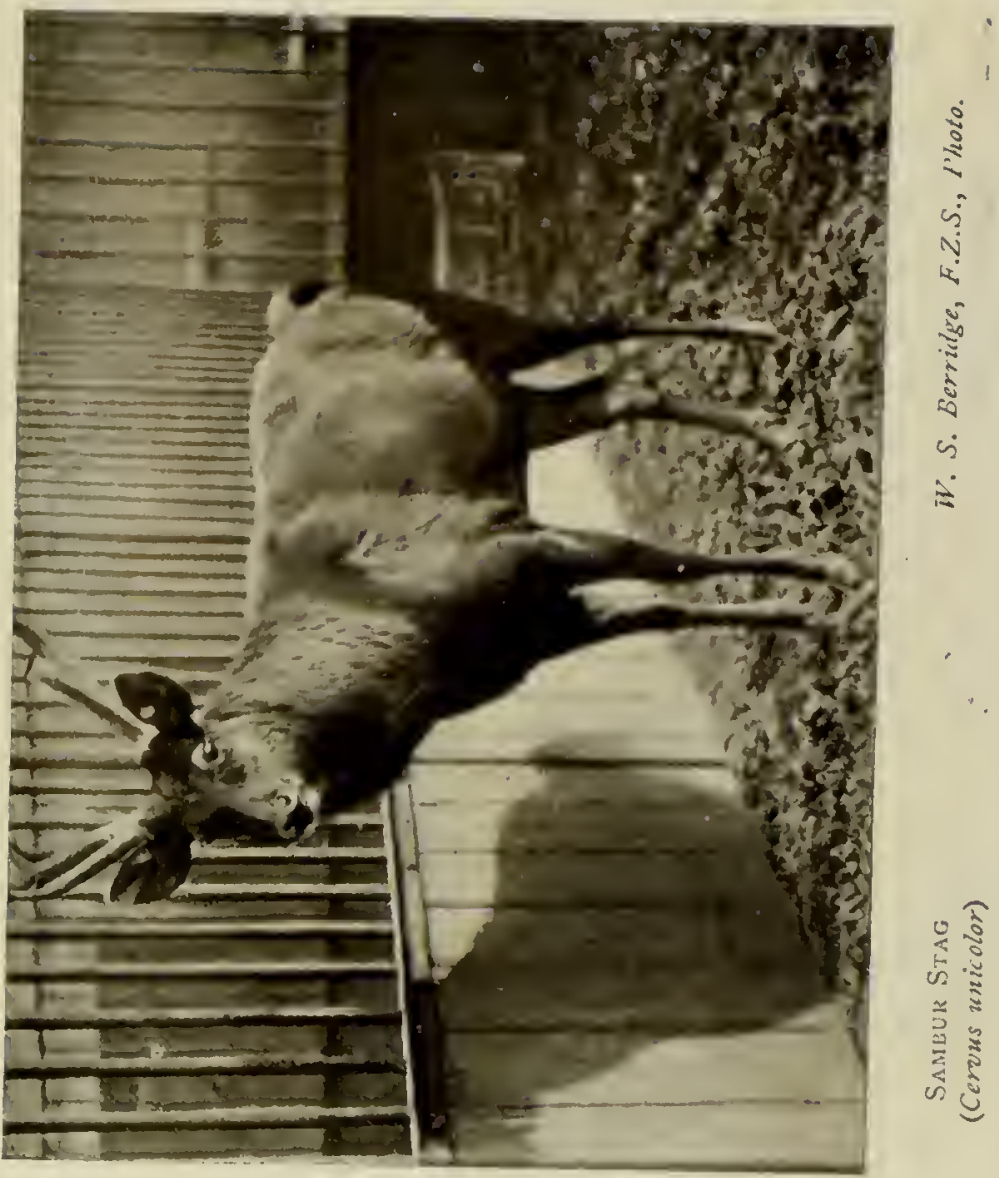




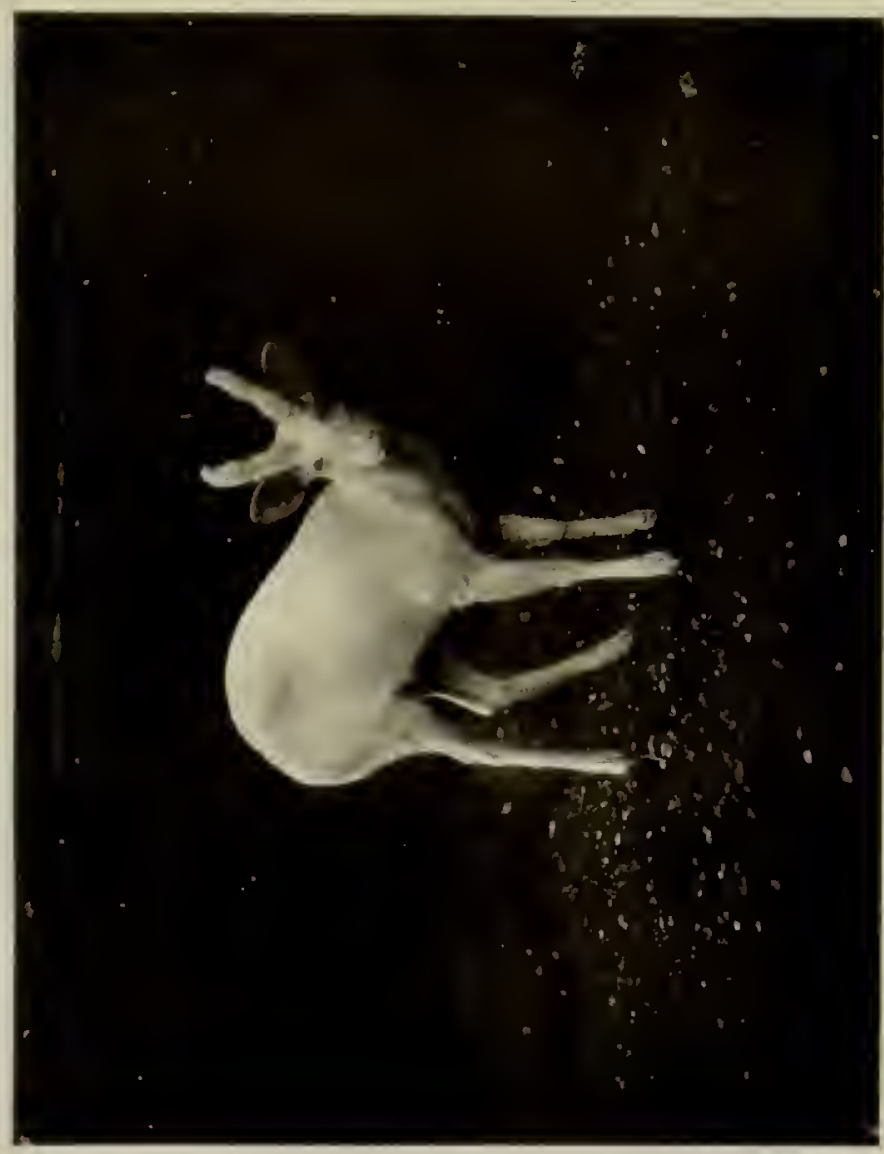

8

sं

N

हैं

s

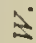

$\frac{3}{3}$

(4)

0

o

눈

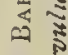

$\frac{1}{0} \cup$

4

ह 


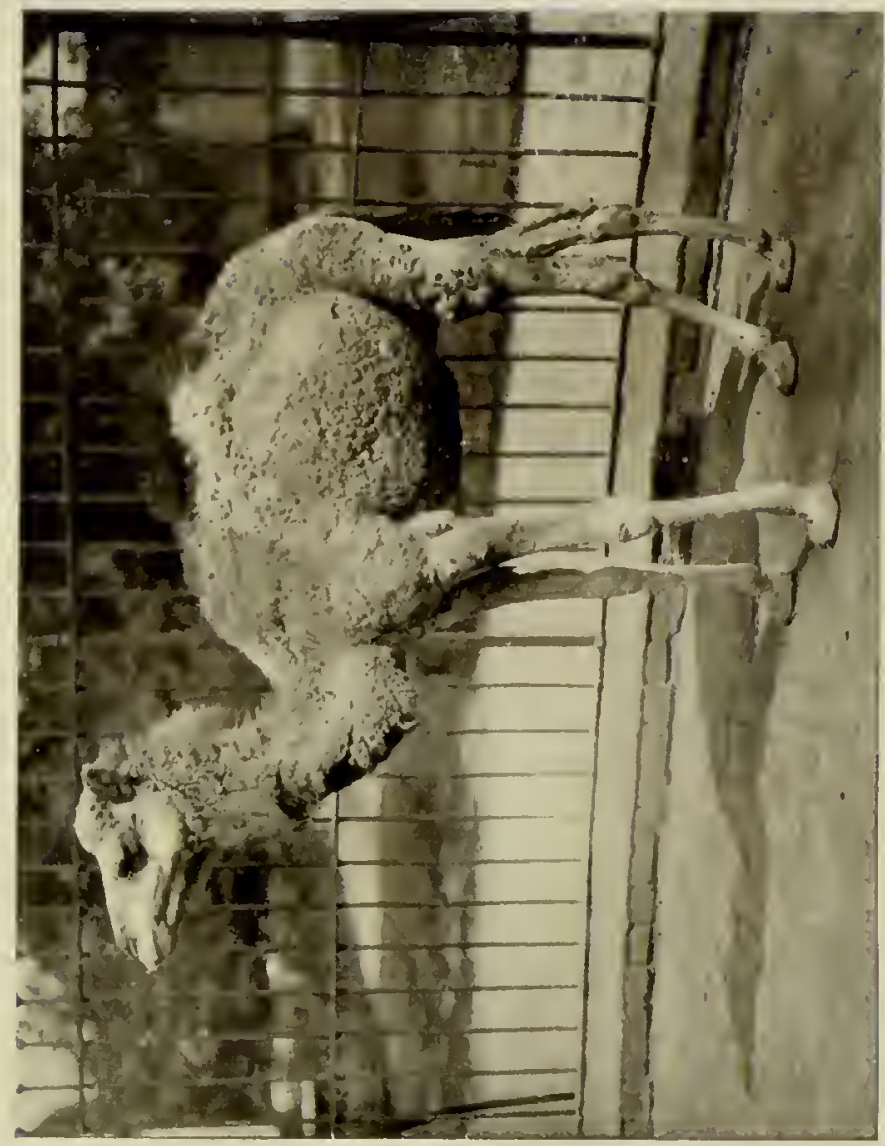

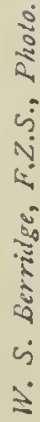

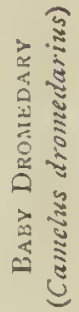




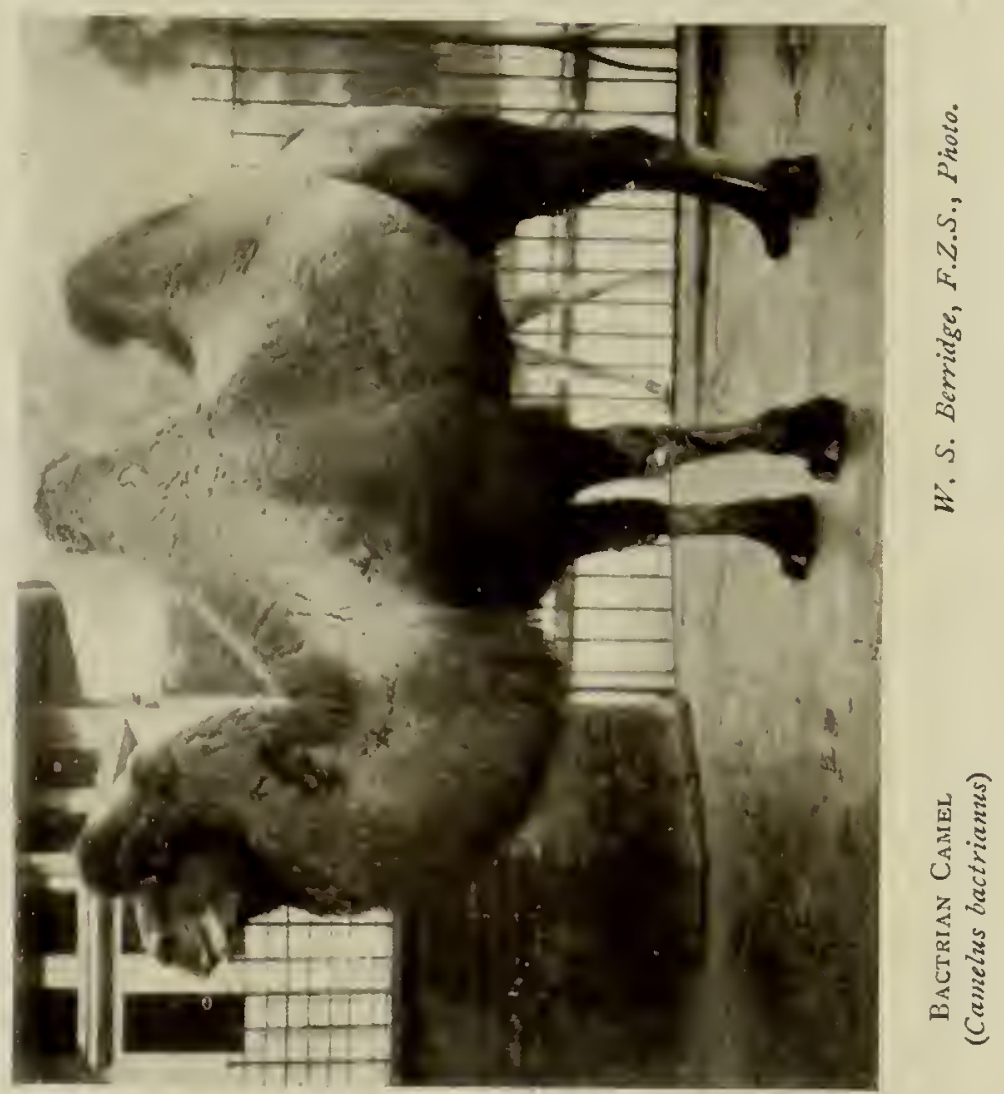




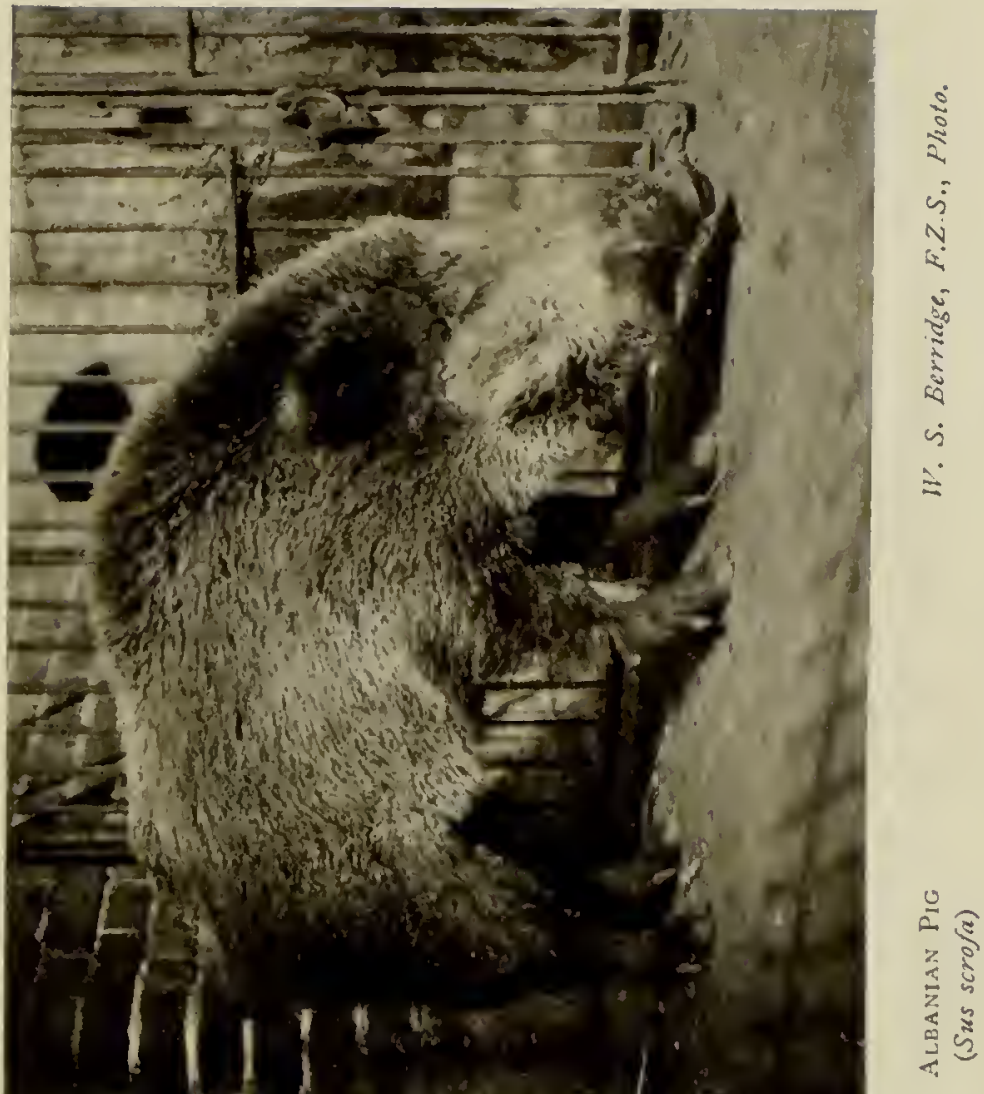




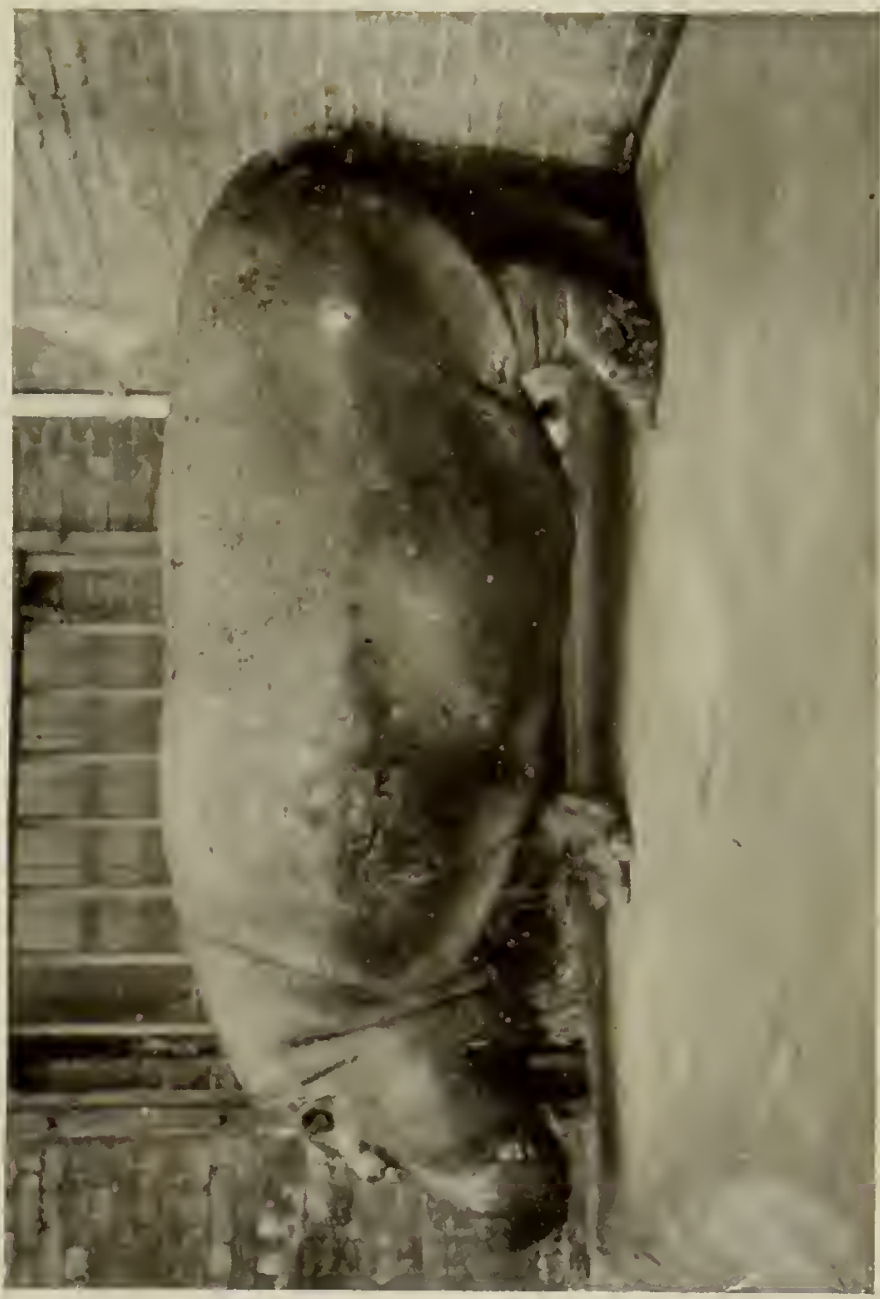

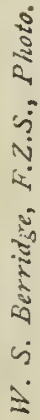

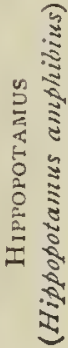




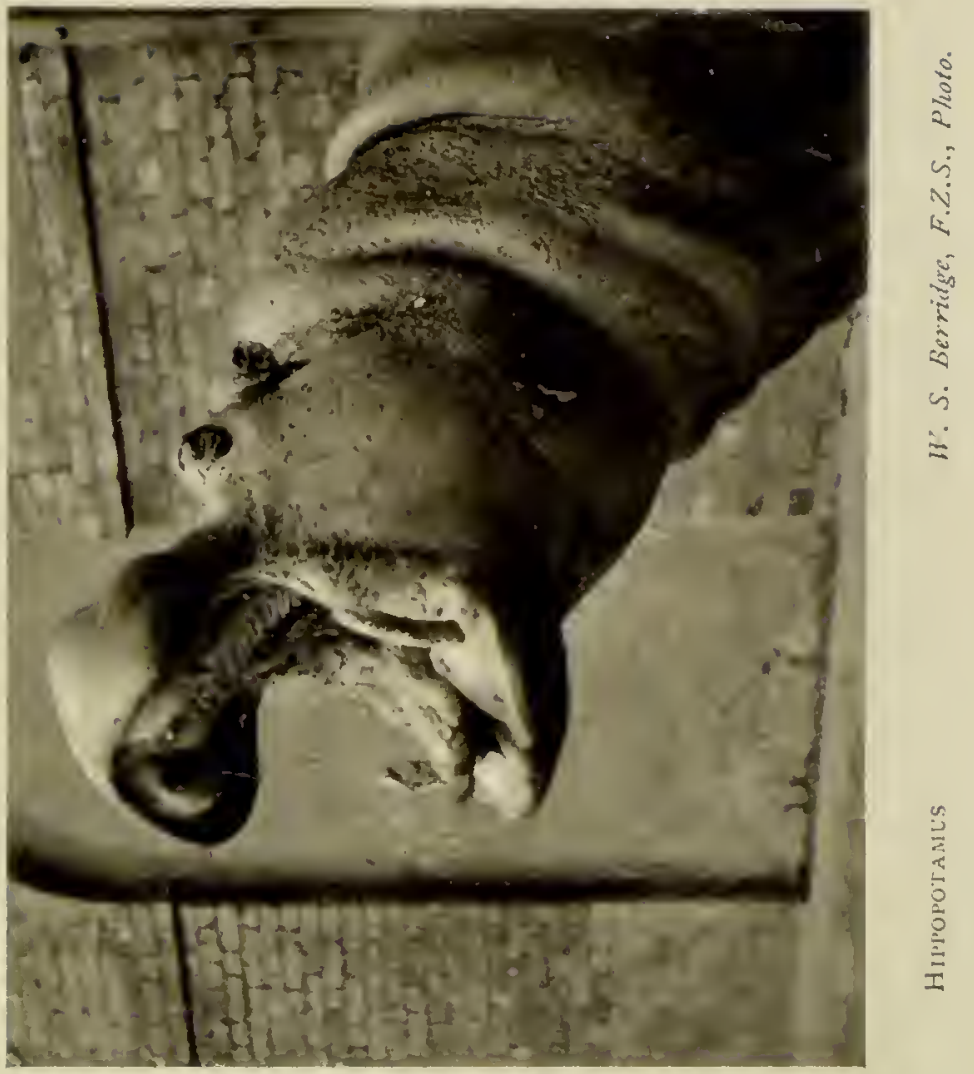




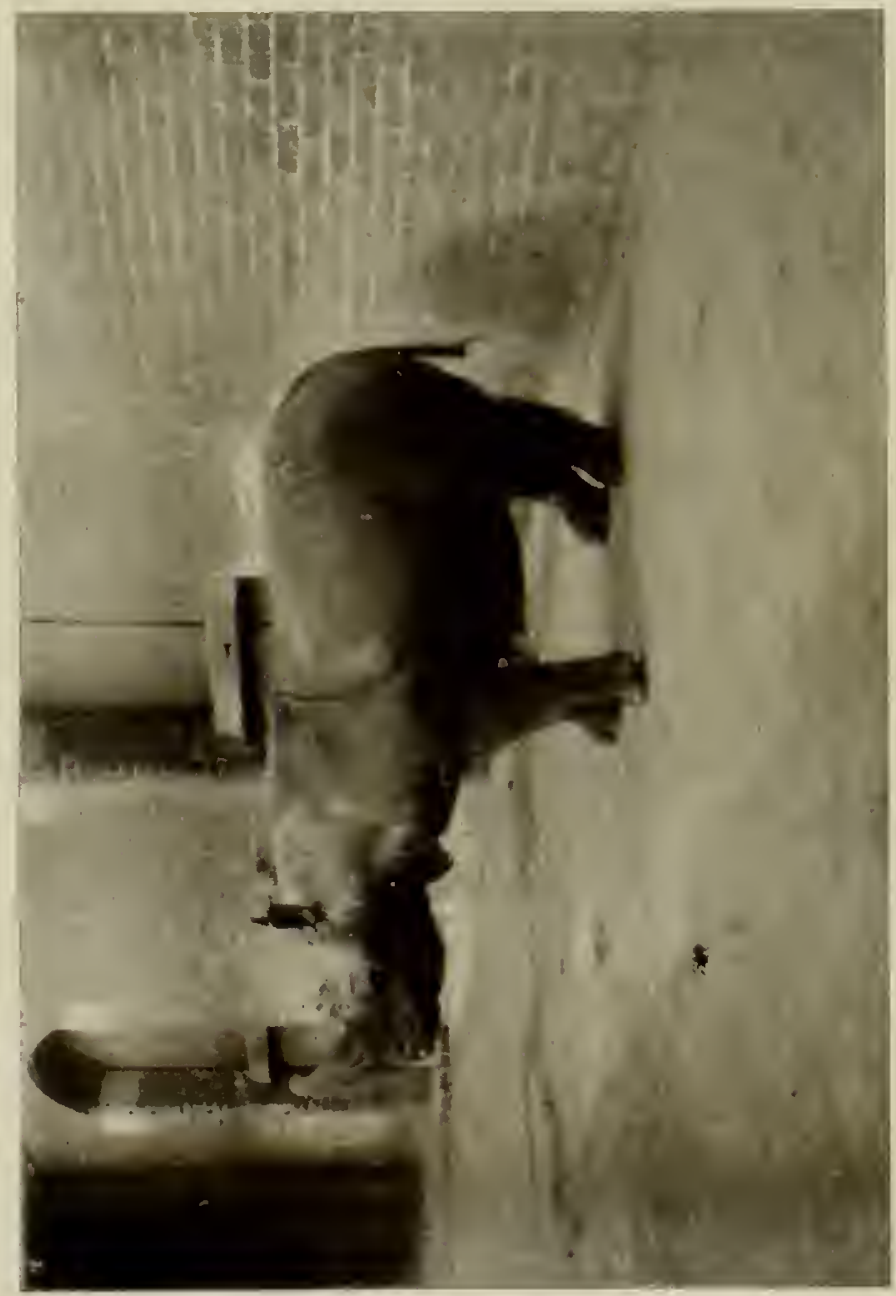

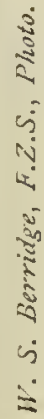

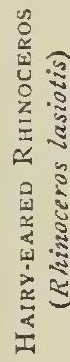




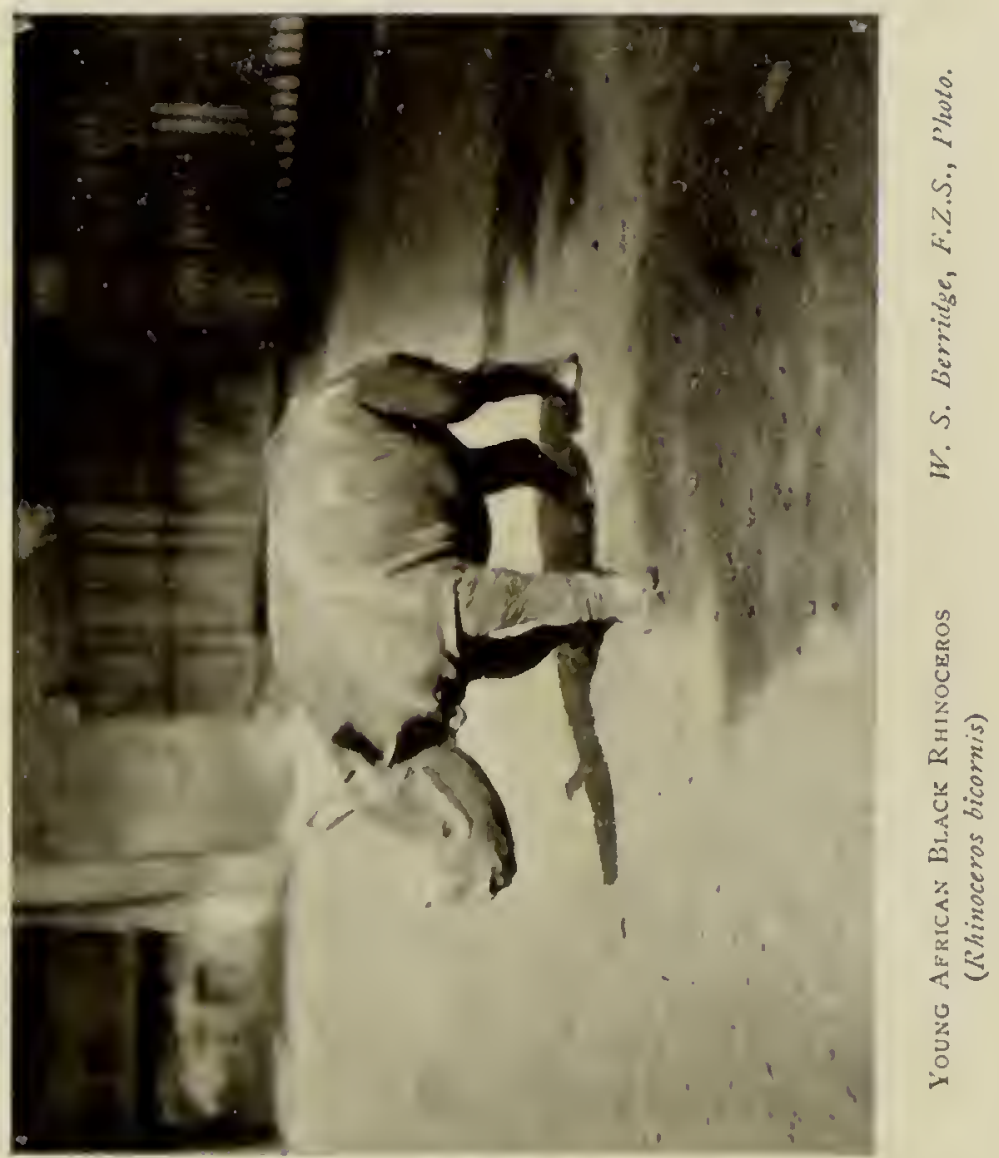




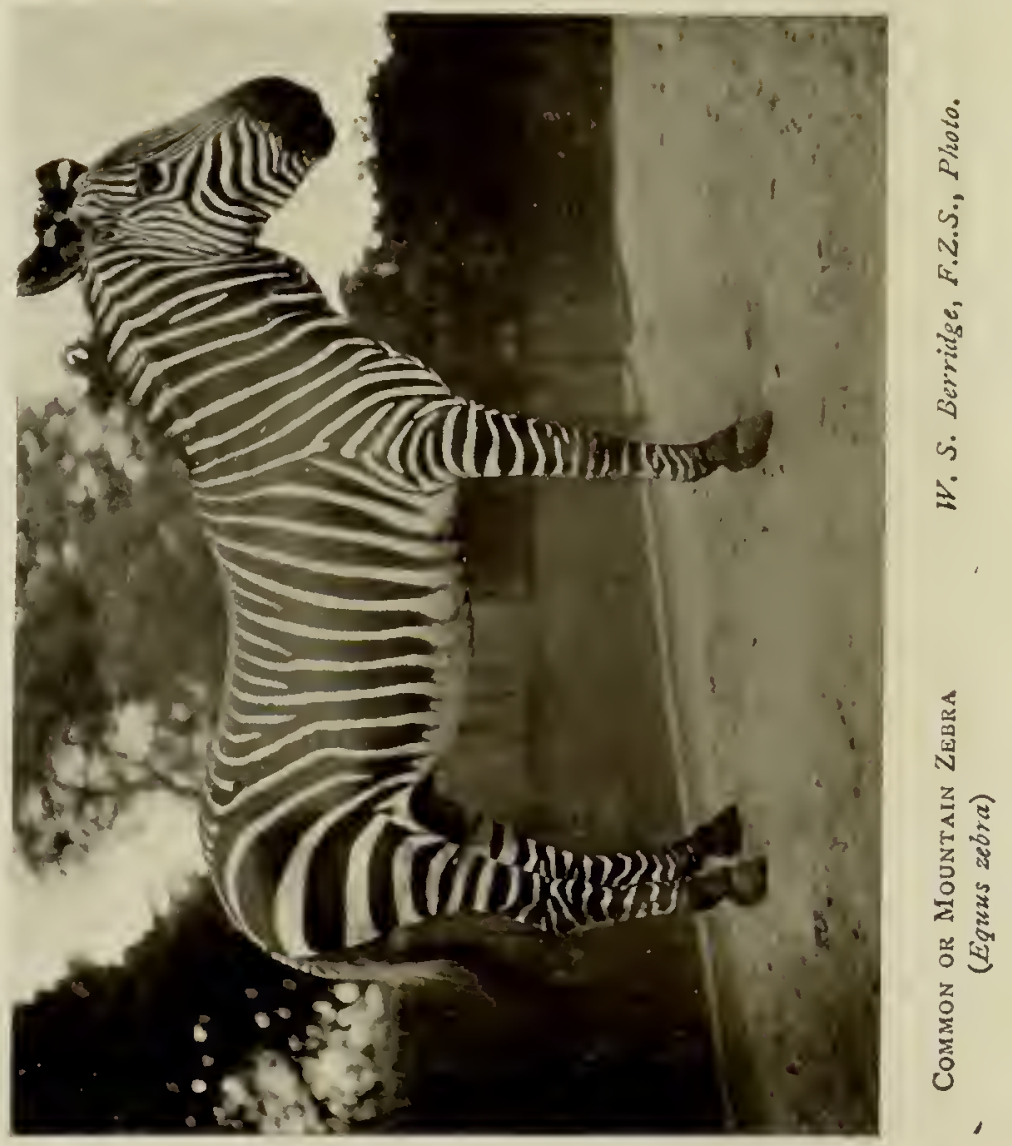




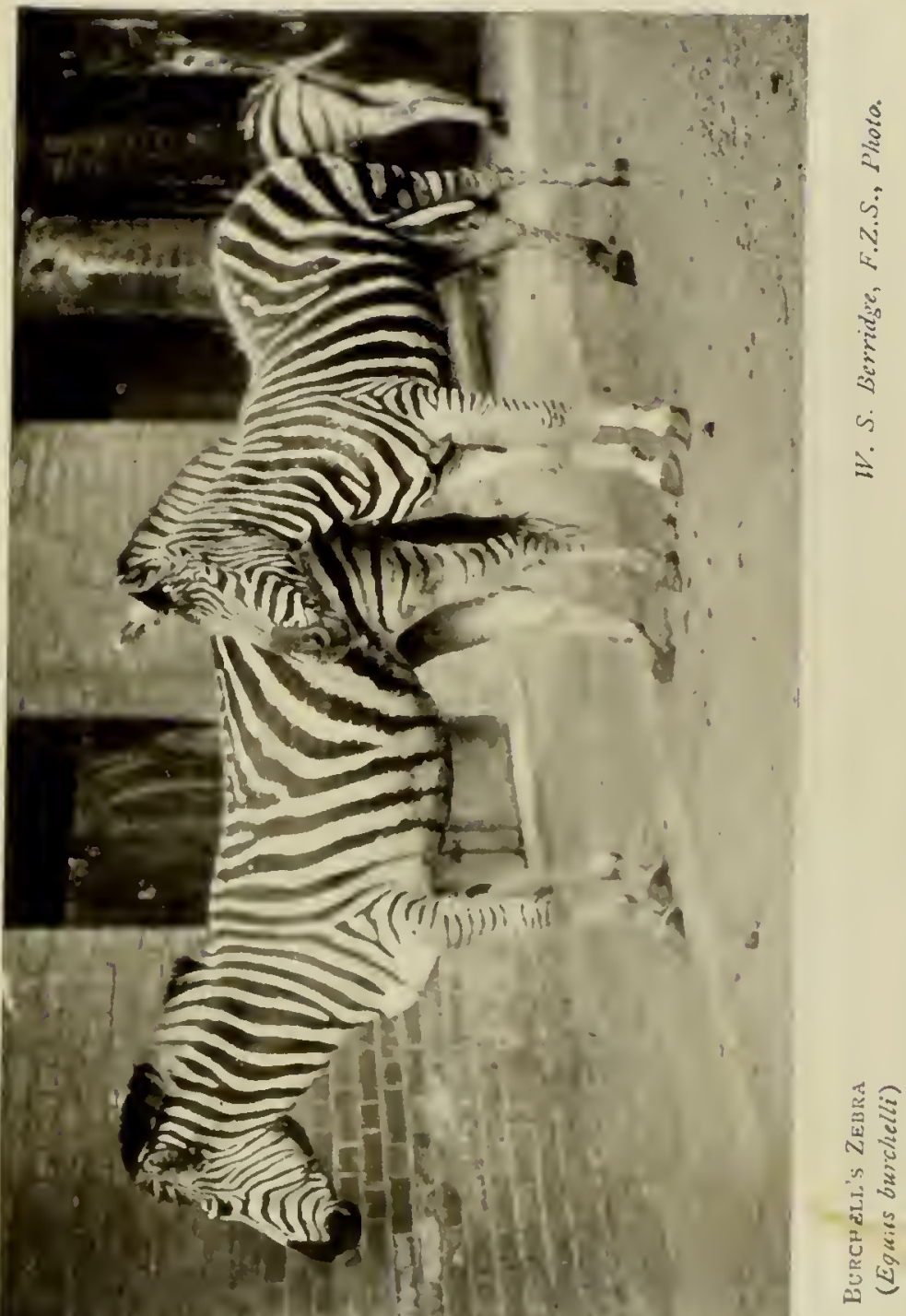




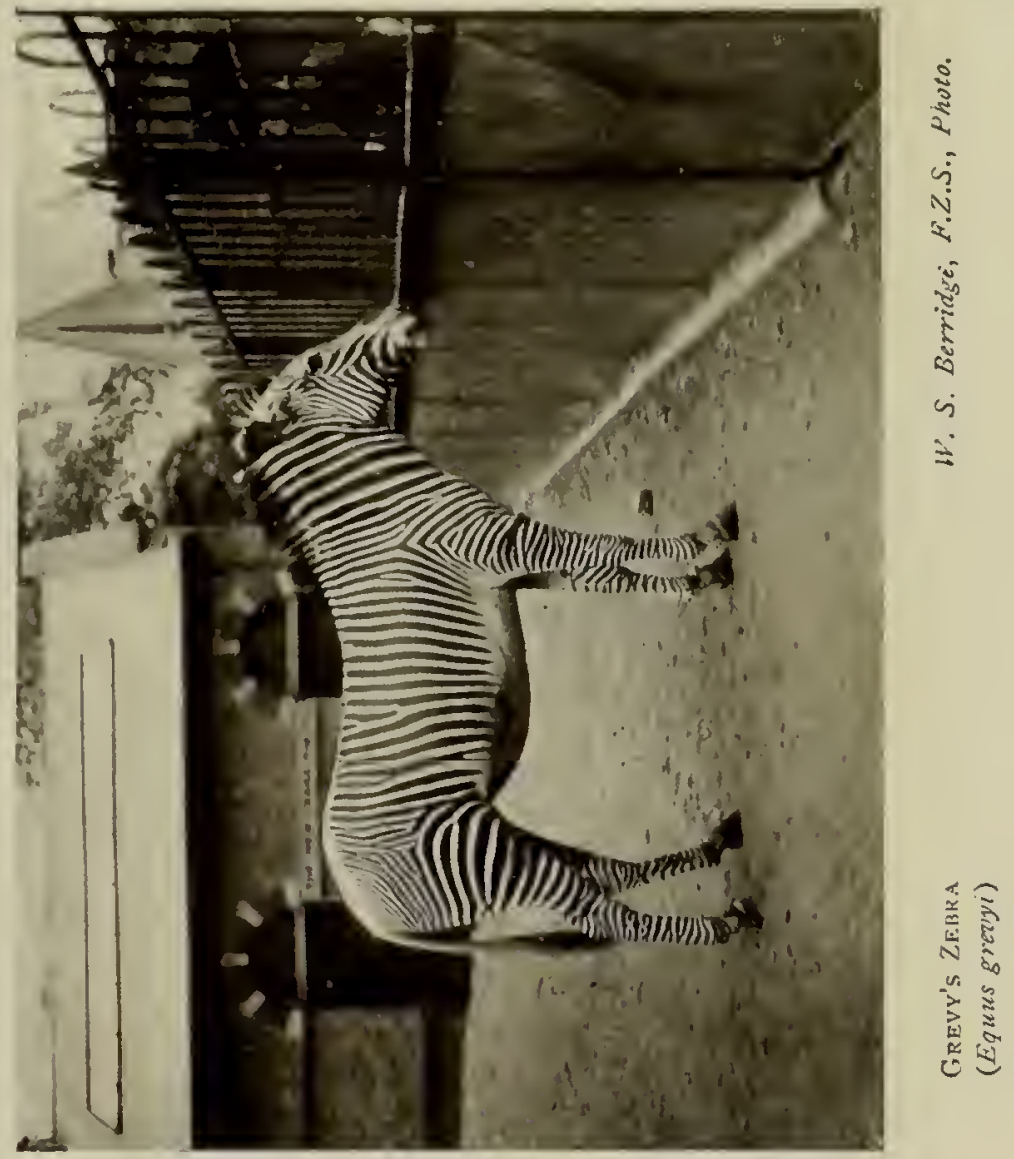




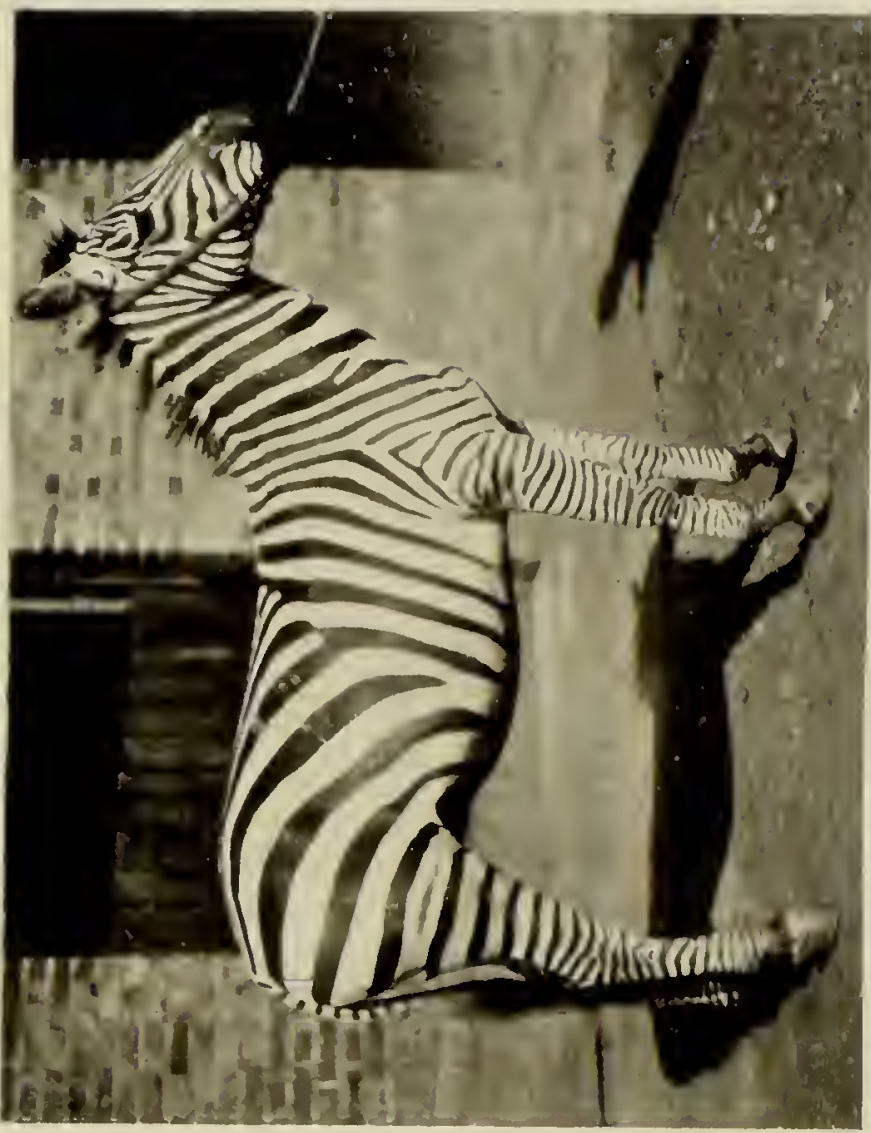

20

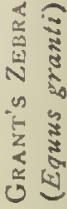




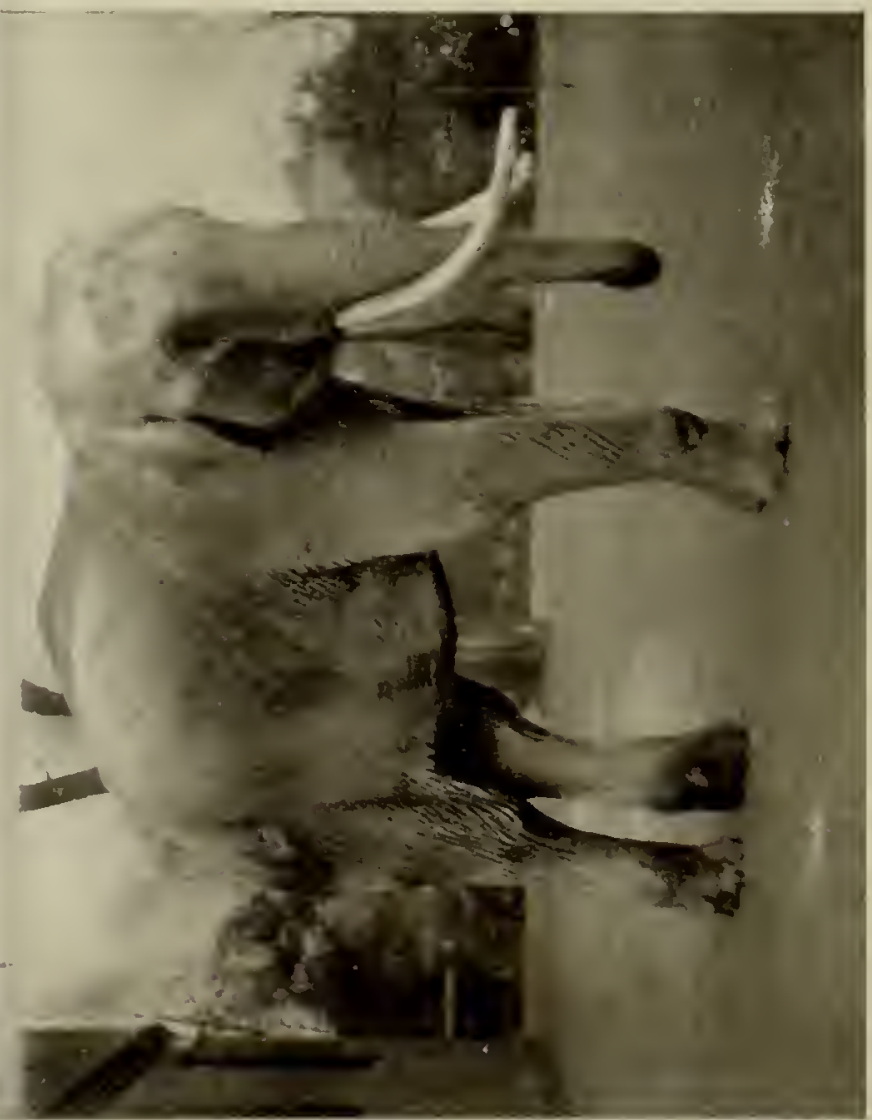

दे

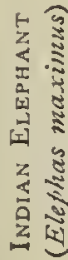




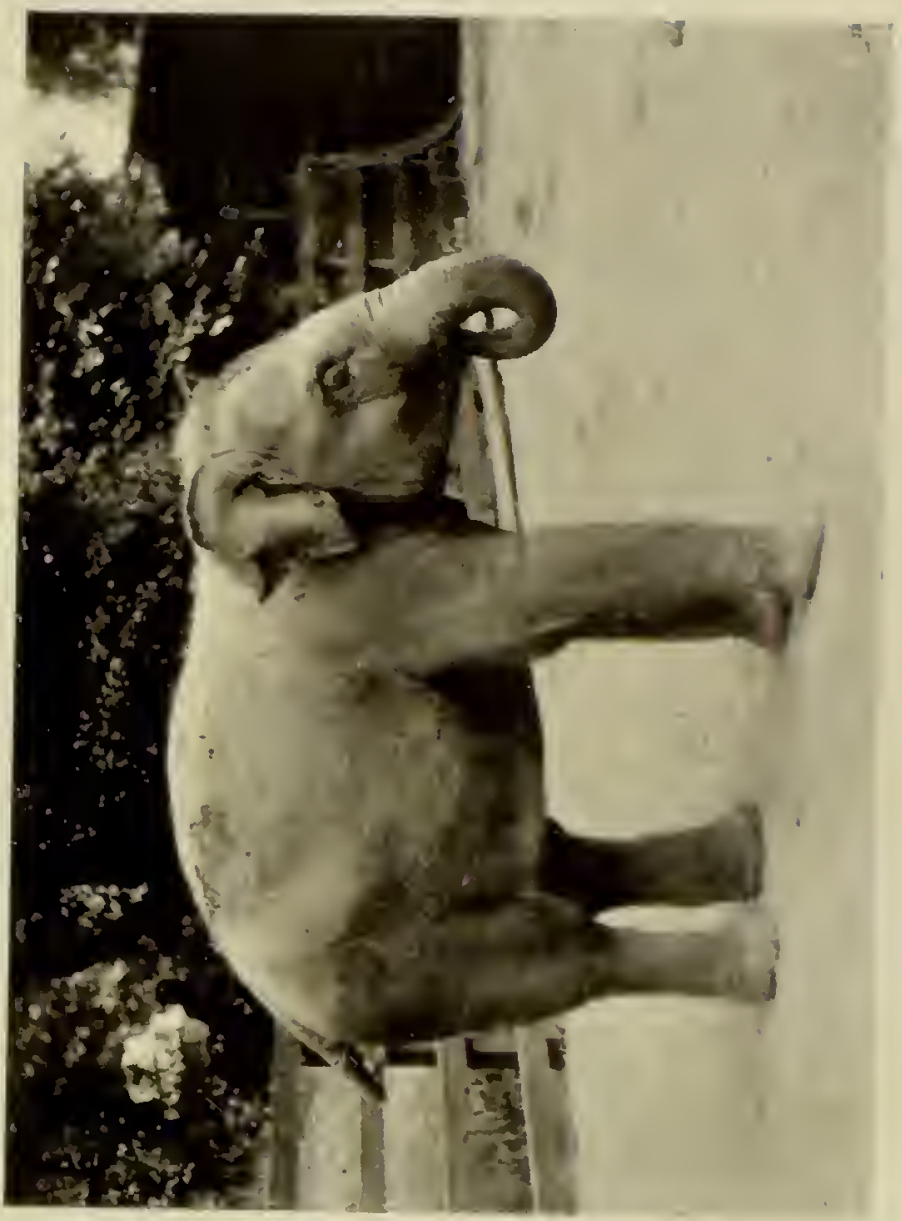

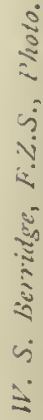

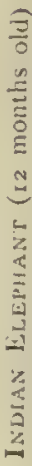




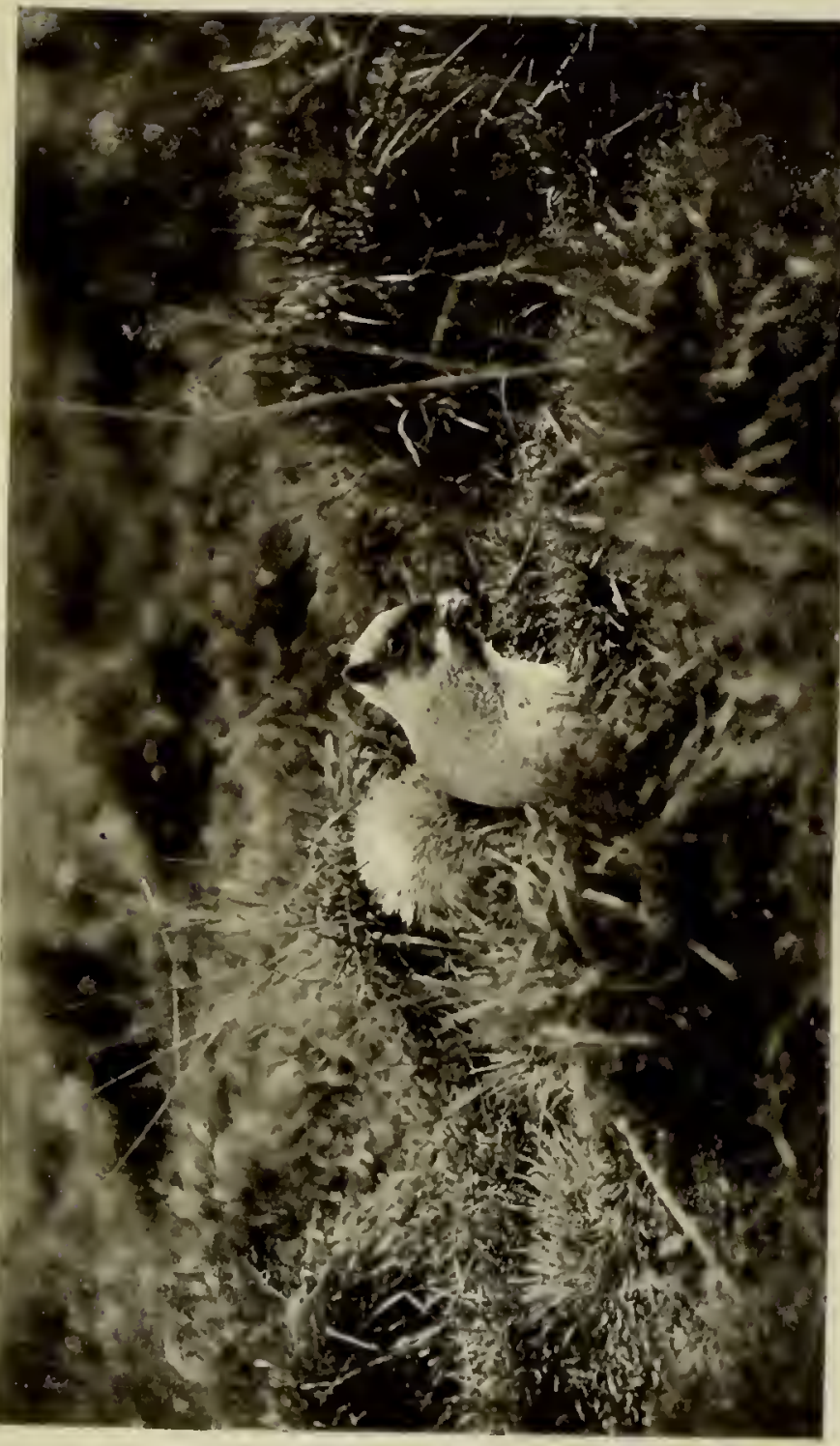

20

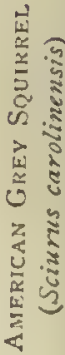




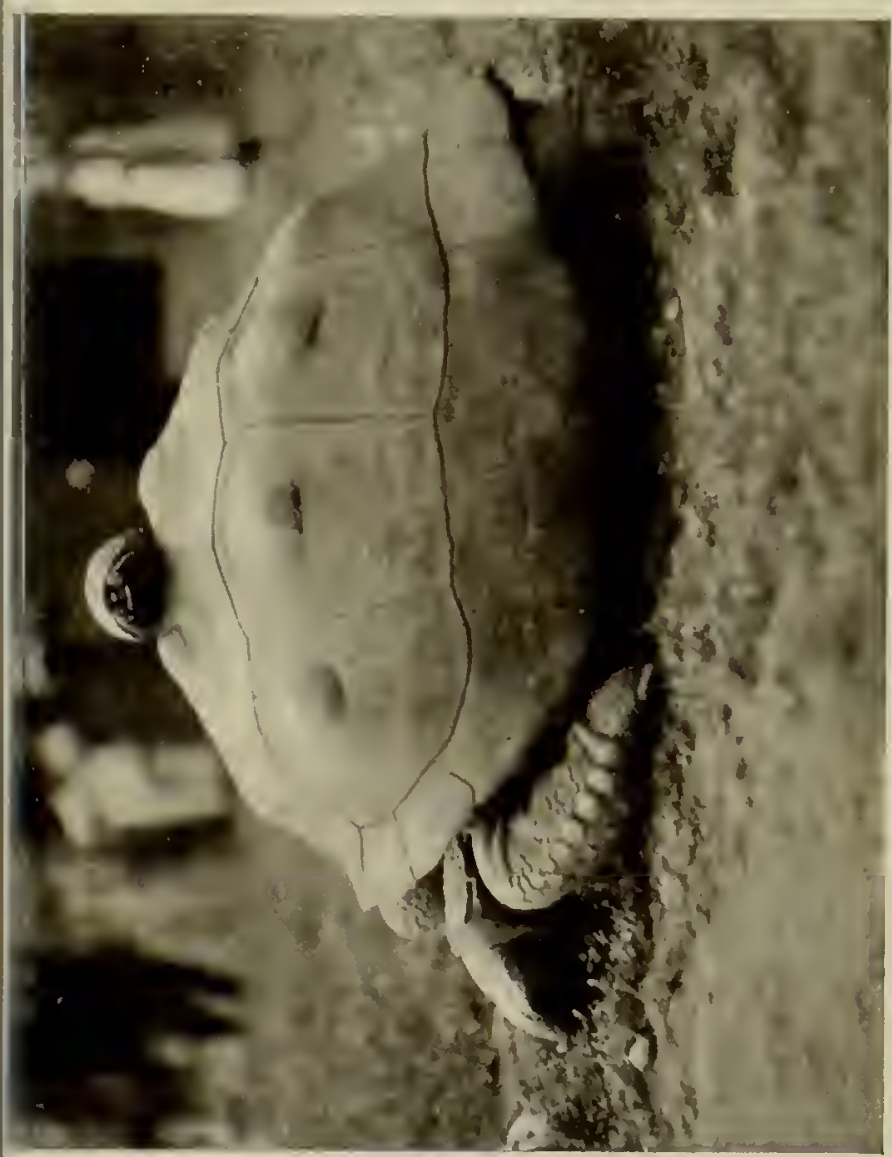

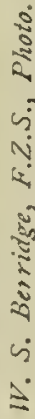

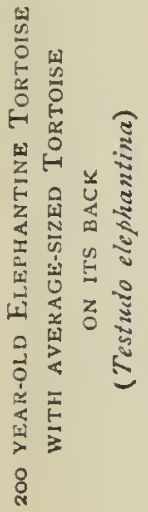




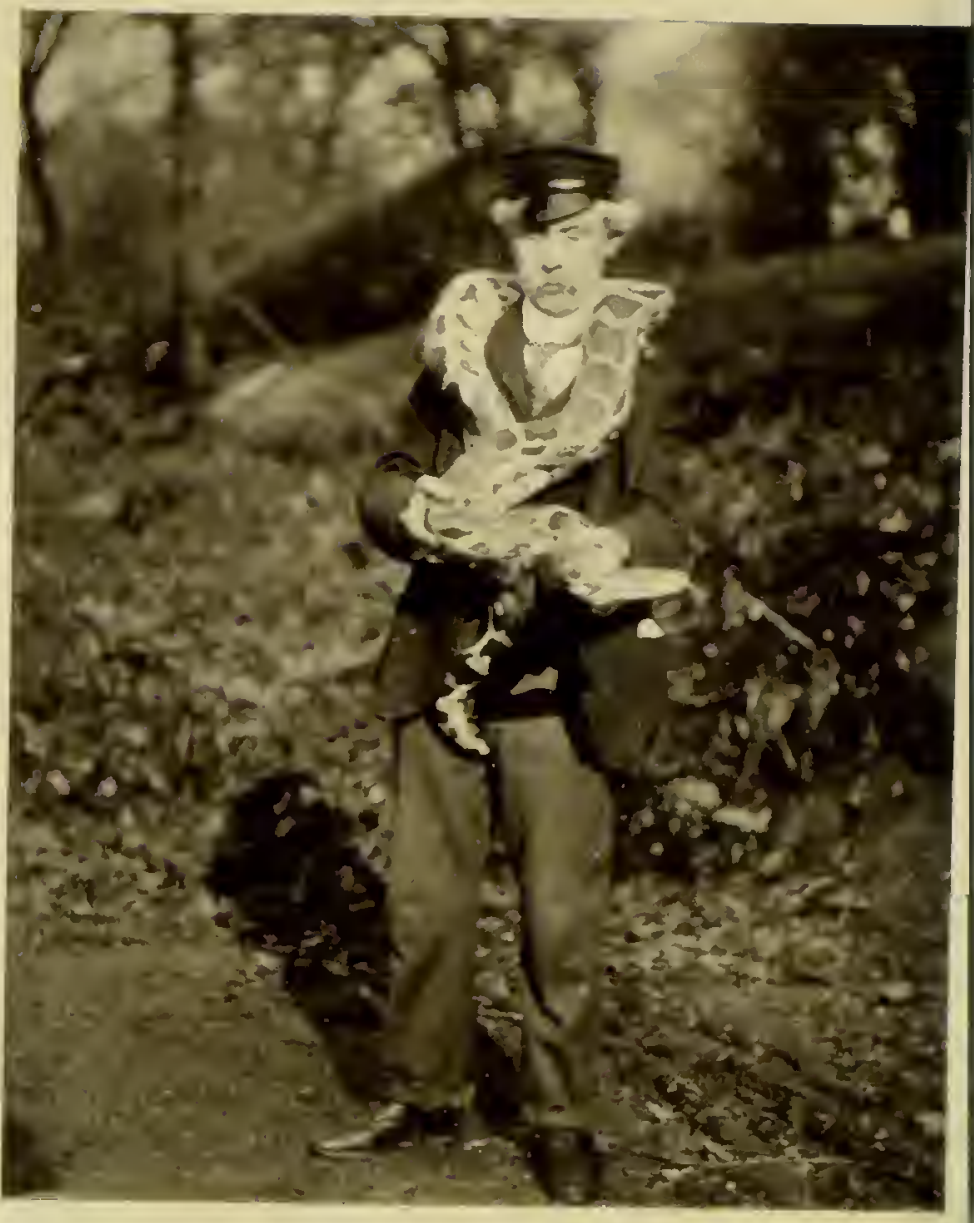

INUIAN PYTHON

W. S. Berridge, F.Z.S., Whoto, (Python molurus) 


\section{Some Notes on the Animals}

OF WHICH

\section{PHOTOGRAPHS APPEAR IN \\ THE FOREGOING PAGES. .}

BY

\section{W.S.BERRIDGE, F.Z.S.}

Chimpanzee (Anthropopithecus troglodytes), Frontispiece. -The man-like apes are the most interesting and intelligent of the inonkey family. They are few in number, including only the Chimpanzees, Orang-utangs, Gorillas, and several kinds of Gihhons. Of these, the Chimpanzee is the best known, and most frequently seen in cap. tivity, and owing to its great intelligence and ahility to learn tricks, is in great demand as a show beast. In expression Chimpanzees differ one from the other very considerably; as is clearly shown in the photograph.

Orang-utang (Simis sntyrus), Page 6.-The Orang-utang is readily distinguished from the other man-like apes, by its long red hair and hrown skin. In captivity it is, as a rule, quiet and affectionate; though it rarely shows the same degree of intelligence as the Chimpanzee, and is also much more lethargic in its movements.

Guinea Baboon (Prpio sphinx), Page 7.-This animal, a native of Gninea, is one of the Baboons most frequently seen in cap. tivity, and like others of its kind is characteristic in having the nostrils situated at the extreme end of the snout. The fact that it has heen called by some writers the "Common Baboon" or "Papio," and by others the "Sphinx" or "Guinea Baboon," has led to considerable confusion. Little is known of its babits in a wild state.

Lion Marmoset (Midas leoninus), Page 8.-The Marmosets, all of which are natives of South and Central America, are of very diminutive proportions, most of them being no larger than a small squirrel. They differ from other Ainerican monkey's in having sharp claws on all fingers and toes (with the exception of the great toe), instead of the usual flattened nails. The "Lion Marmoset," often called the "Silky Marmoset," is the prettiest of the group, its long golden mane giving it the appearance of a dwarf lion. These animals are somewhat difficult to keep in captivity, owing to the ease with which they catch cold.

Grey Slow Loris (Nycticebus cinereus), Page 9.-The Loris, or Slow Lemur, is a nocturnal animal, belonging to the monkey tribe. Its mode of feeding is to prowl about the branches of trees at night, pouncing upon any small defenceless bird it may happen to come across. In size it is about that of a guinea pig, which it reseinbles in having no tail. 
Lion (Felis leo), Pages ro and Ir. - The Lion is usually" called the "king of beasts," but it is a matter of doubt whetber it is entilled to sucb a proud distinction, for the Tiger is as a rule by far more dangerous and courageous. However, as regards appearance, a fine male Lion certainly gives one the impression of grandeur and majesty. The young, of which there are sometimes as many as six in 2 litter, are spotted, and they have their eyes open at birtb. lions frequently breed in captivity, though rarely, at the London Zoo. In a wild state they are nocturnal in their habits.

Tiger (Felis tigris), Pages 12 and 13. - The Tiger, like tbe Lion, is a nocturnal beast, lying concealed in long grass and undergrowtb during the daytime. Tigers greatly dislike the intense heat of the sun, and to cool themselves will roll in the shallow pools of any streams which may be at hand; they are adepts at swimming, and take readily to the water. The usual number of cubs found in a litter is two, although as inany as six have been known. The najority of Tigers are natives of India, though there are some found in Siberia, which, owing to the very long sbagsy coat they grow in the winter, are well able to withstand the rigours of tbe climate.

Ocelot (Felis pardalis), Page 14.-This animal is somewhat larger than our donestic cal, and is found in considerable numbers in South Anerica. It lives in the thick forests of that region, spending the greater part of its time amongst tbe branches of the trees, in search of the small mammals and birds upon which it feeds. It is very fierce and dangerous in a wild state.

Aard - Wolf (Proteles cristatus), Page 15. - This animal has been much discussed in zoological circles, for although undoubtedly akin to the Hyena, yet in many respects it differs considerably from it. However, it is now recognised as being the solitary representative of a distinct family. It is a native of Africa, where it is by no means plentiful. Entirely nocturnal in its habits, during the daytime it hides in burrows which it has excavated for itself. In size it is very inferior to the Hyenz, being compared to a large leggy fox.

Timber Wolf (Canis occidentalis), Page r6.-The Timber Wolf of North America, although at one time very plentiful, is fast disappearing, and can only be found in any numbers in the renote and wild parts of the country. Tinber wolves are usually found in pairs, though in the winter they wi'l sometimes congregate in lar:e numbers. They wander about both by day and night, and when pressed by bunger become both bold and dangerous. The number of cubs born in a litter is from 6 to 10 . "These appear in the spring and remain with their parents until November or December, but ocrasionally for a longer period.

Dingo Dog (Caris dingo), Pages 17 and 18.-The Dingo is the wild dog of Australia, though it is now recognised as not being a true native of that part, but as having been introduced by man at a very early date. In colour, different specin ens vary one from the other very considerably, ranging from red to black, whilst the puppies shown in our photograph are pure white. It is a great enemy of the farmers, owing to the number of sheep it kills; for it will destroy in one night many more than it can possibly eat. When captured Dingos usually feign death; sometimes with such success that they are able to make good thoir escape. The usual number of cubs in a litter is from six to eight. In their natural state they never bark, though in captivity, when brouglit into cot tact with other dogs, readily learn to do so. They are rarely seen during tbe daytime. 
Indian Wild Dog (Canis dukkunensis), Page 19.-This dog is found from the Himalayas southwards; but not in Ceylon. It lives principally upon deer, wild pigs, wild sheep, and antelopes, hunting them botb by day and night, though chitfly during the daytime. It hunts in companies of from 6 to 10 , but rarely attacks domestic animals, avoiding the neighbourhood of man.

American Red Fox (Canis fulvus), Page 20.-This aninal differs little from the ordinary English lox, except in its coluuring, which is lighter and brighter. In haloits it is also similar, feeding upon small mammals and birds, though when food is scarce it will readily take to a diet of frogs and worms. From 4 to 6 cubs are found in a litter.

Arctic Fox (Canis lagopus), Page 2r.-The great point of interest in Arctic Foxes lies in the fact that their coat, which during tbe summer months is of a dirty brown colour, is changed to one of a pure white in the winter; although this change does not always occur, certain individuals never attaining the puse white stage. They feed principally upon the Arctic birds as well as upon their eggs.

Indian Desert Fox (Caris lewcopus), Page 22. - This Fox is considerably smaller than the common species, the head and body being only some ig or 20 inches in length?; in colour it is also paler. It is found in the sandy desert regions of India, and parts of Persia and Arabia. The chief food of the Indian species is Gerbils, wbicb are so plentiful in the sandy districts.

Polar Bear (Ursus maritimus), Page 23. -This bear is readily distinguished from all others by the uniform white colour of its coat, which rentains of the same colour at all seasons, not being changed in the summer for one of a darker hue, as is the case with the Arctic Fox. It is the largest of its kind, often growing to a length of $9 \mathrm{ft}$. Found in the Arctic regions amnng the snow and ice, it feeds principally upon seal and walrus, although it will resort to a vegetable diet. Owing to the fact that the soles of its feet are partially covered with hair, it is able to move about upon the slippery ice at a remarkably quick pace. It is a very powerful swimmer, taking to the water readily.

Himalayan Black Bear (Ursus tiretanus), Pages 24 and $25-$ The distinguishing mark of this bear lies in the crescent-like white mark across the chest. In size it is inferior to many others, the average specimen being only some $4 \frac{1}{2}$ to 5 feet in length. It is a forest. dwelling animal, subsisting chiefly upon regetable matter, such as nuts, nuaize, berries, acorns and roots, though at times it will kill cattle. It is very nunierous in its haunts it being no uncommon sight to see as many as 2 or 3 in one tree in search of food. These bears are very good climbers, and for that reason have been given a tall pole to nount at the Zou.

Syrian Bear (Ursus sysiacus), Page 26. -The Syrian Bear, of which a young specimen is dericted, is a somewbat larger animal than the Himalayan, and in colour is of a light silvery brown. Its habits are similar 10 the latter, and it is equally proficient as a climber. Both species are very fond of honey, for which they make diligent search. The bears which are frequently seen performing in the streets are very often of tbis species.

Otter (Lutralutra), Page 27. - The Otter is essentially a waterloving animal, and for powers of swimming and diving it has no rival. It lives upon fish, of which it kills many more than it can eat ; though when these are scarce, it will readily attack the feathered inmates of the farmyard. The young, which are born blind are usually from 2 to 5 in numher. If captured young they make ideal pets, following their owner about lite a dog. 
Californian Sea Lion (Otaria califormana) Page 28. - The Sea Lions, or Eared Seals, are those from which the sealskin of com. merce is obtained, this being the under fur, the coarse outer hairs of the coat having been first removed. Their breeding places are known as "rookeries," where they assemble in vast numbers, fighting for the possession of the different stations and for the females. At one time great numbers were slaughtered annually, but now their favourite breeding places are protected by the United States Govern. ment. They become very tame and gentle in captivity, showing a large amount of intelligence. Their cry is a rather harsh bark and not at all pleasing.

Common Seal (Pheca vitulina), Page 29.--The Seal is distinguished from the Sea Lion, by having no external ear tufts. also in having the hind flippers permanently directed backwards. In size it is very inferior. It is more adapted for a purely acquatic life than the Sea Lion, being able to remain under water for a period of 15 minutes, though it has been stated upon good authority that 30 minutes is not too long for it. The young are of themselves unable to swim and have to be taught by their parents. On land its movements are decidedly clumsy.

Zebu (Bos indicus), Page 30.-Zehus are the domestic humped cattle of Indh. As regards size the different species vary one from the other considerably - the largest standing as high as an ox, whilst the smallest are not much bigger than a very young calf. These aniraals are looked upon 25 sacred, and certain bulls are protected by the natives, and allowed to roam about the towns and villages at will. The larger species are used for drawing the native carts.

Banteng (Bos sondaicus) Page $3 x$-The Banteng or Javan Ox, is an animal rarely seen in captivity. Of its habits very little is known, thougl the domestic variety breeds freely with the Zebu. The specimen depicted is a young aninal.

American Bison (Bison americanus). Page 32.- This noble animal, once so plentiful, is now fast approaching extinction. There are, however, still a few left, which receive protection at the hands of the American Government, notably the small herd in the Fellowstone Park, numbering about 20 specimens. It is stated that hetween the jears 1872 and 1874 , no fewer than $3 \frac{1}{2}$ millions of one herd were slaughtered. The photograph is of a cow, which differs from the bull in having a smaller head, and being less massive in proportion.

Blandford's Sheep (Ovis vignei, van blandfordi), Page 33.This sheep, named after the well-known explorer and zoologist William Thomas Blandford, is a variety of the Ural or Punjaub wild sheep. It is found in Baluchistan, and is notable for the very widespread spiral of its horns. It is an active animal, and gets over the steep ground of the hillsicies with great rapidity.

Burrhel Wild Sheep (Oris nahura), Page 34,- These sheep are found in Tibet, in herds varying in numbers from 8 to as many 2s 100. They are remarkable climbers, and when alarmed rush a way to inaccessihle parts where inan cannot follow. In captivity they breed freely.

Barbary Sheep (Ammotragus lenvia), Page 35.-Also known as $\mathrm{the}$ Maned Sheep. "These animals are found in Árica. They are great adepts at hiding themselves, even where there is little rover, sitting motionless beside some stone or small bush, their earth like colouring making it dificult to distinguish them even at a compara. tively short distance. 
Serow (Capricornis thar), Page 36.-Serows are also known as Goat-antelopes. Tbe common Serow, which is depicted, is a native of the Himalayas, where it is not very plentiful. Serows are only found in small companies of 3 or 4 , and frequent tbe steepest and most inaccessible slopes of the bills. Although shy animals, they are dangerous and fierce when disturbed.

Rocky Mountain Goat (Oreamnos montanzs), Page 37.-Tbis fine animal is rarely to be seen in captivity, the specimen depicted being the only living example in Furope. In its native parts it spends most of its time amongst the mountains, but wben pressed by hunger, will descend to lower pastures. It has beel knowu to swim in order to reach a desired spot. In colour it is white, with a slight creamy tinge.

Eland (Taurotragus ory $x$ ), Pages 38 and 39 . - The Eland is the largest of the Antelope tribe, tbe average height for an adult bull being some 5 feet 9 incbes at the withers. At one time Elands were plentiful in Soutb, East, and Central Africa, though tbey are now no longer to be found in Cape Colony and tbe adjoining parts. As large numbers are slaughtered for the sake of tbeir hides, tbey are fast joining the ranks of disappearing animals. They are usually found in large herds, the numbers varying from 50 to 100. In captivity tbey breed freely. The accompanying photographs sbow an adult bull, and a cow with her 4 days old calif.

Springbok (Gazella euchore), Page 40.--Tbe Springbok is found in South Africa, and derives its nane from the manner in which it bounds and springs along the ground when running, at times taking sudden leaps in the air. The band of erectile white hairs running down tbe centre of tbe back is peculiar to this animal, but is only to be fully seen when the animal is excited, the darker hairs of the back closing over it from either side in its normal condition.

Blessbok (Damaliscus albifrons), Page 4I.-The Blessbok, another of tbe Soutb African Antelopes, is an animal standing about 3 feet 2 inches at the withers. It congregates in large herds, but as is the case with all tbe South African mammals, tbe advance of civilization is driving it to remoter parts as well as considerably dimirishing its numbers.

Giraffe (Girnffa camelopardalis), Pages 42 and 43.-Tbe Giraffe is the sole representative of its family, and bolds tbe distinction of being tbe tallest of living animals, 18 or $\times 9$ feet being by no means an unusual beight for an adult bull. It is found in South Africa, but its numbers are fast dwindling, and its range getting more restricted. The food of Giraffes consists principally of leaves, whicb tbey pluck from the trees with the aid of tbeir long flexible tongues. They not infrequently breed in captivity.

Turkestan Wapiti (Cervus bactrianus), Page 44.-The Wapiti Deer are large in size, 2 full grown stag standing 17 bands at the shoulder ( 5 feet 8 inches). As with most deer, the borns are shed annually. The stags live apart from the rest of the berd, during the greater part of the year, but during the breeding season take cbarge of the party of hinds, after having first settled disputes with tbeir rivals, by a series of fights, which, bowever, rarely prove fatal.

Spotted Deer (Cervres axis), Page 45.-Also known as the Chital or Axis, this animal is of comparatively small dimensions, rarely standing more than 3 feet 2 inches at the withers. Chitals are found in most parts of India and Ceylon, though they differ considerably in size in different localities. Tbey are usually to be found in herds of from ro to $3^{\circ}$ Tbey swim well, taking readily to the water. 
Sambur (Cervus uricolor), Page 46. - The Sanbur is a large animal, being about 5 feet or more in height at the withers. In colour it is of a very dark brown. It is found in the hilly and wooded districts of India and Ceylon. During the heat of the day it lies in concealment, grazing chiefly hy night.

Muntjac (Cervulus muntjac), Page 47.-The Muntjac, a native of India, is also known as the Barking Deer, on account of the curious bark.like cry it gives forth. It is a small animal, being about 22 inches high at the shoulder. 'The two ridges which run down the face in the form of a V, are a peculiarity of this animal. The photograph represents an albino specimen.

Dromedary (Camelus dromedarius), Page 48.-There are two species of Cantel, the one-liumped and the two-humped. The true or Arabian Camel is found in Africa and Asia, and has but one hump. The term Dromedary is given to the hetter class of these, which are used for riding purposes; whilst the inferior beasts are used as baggage camels. The difference between these classes is as distinct as between that of a race-horse and a cart-horse.

Bactrian Camel (Camelus bactrianus), Page 49.-The Bactrian Cansel of Central Asia, differs from the Arabian in having two humps, also in its build, which is heavier and more clunsy, the hair being longer and thicker. 'The temper of all camels is vicious and sour, and at no time do they show the least affection for their master.

Albanian Pig (Sus scrofo), Page 50.-In size this pig varies from 30 to 40 inches at the shoukder, whilst in weight 300 lhs. or more is by no neans unusual. In their native parts pigs of this species inhabit noist and marshy' neighbourhoods, searching for food amongst the loose ground. The number of young born in a litter is from 6 to ro, and it is cuminon for two hitters to be produced during the year.

Hippopotamus (Hippopotamus amphibius), Pages 5 I and 52.The nane 1 ippopotamus, derived from the Greek, signifies" River Horse." Hippopotami are ungainly beasts of huge girtl. A specimen which once lived at the Zoo, weighed close upon 4 tons. Entirely aquatic in their liabits, these creatures live upon grasses and water plants, of which they cat enomous quantities. They thrive well in captivity and not intrequently breed.

Hairy.eared Rhinoceros (Rhinoceros lasiotis), Page 53.-The Hairy-eared Rhinoceros, a native of India, approximates very closely to the Sumatran Rlinoceros; hut from its having a more hairy appearance, especially due to the tufts upon the ears, and because of its paler colour, it is regarded as a distirict species. The horns are two in number.

African Black Rhinoceros (Khinocers bicornis), Page 54.This species also possesses two horns, but these are nsually of a larger size than those of their Asiatic brethren; the African animals also differ in having no permanent folds in the skin, a feature which is so inarked in the Indian Rhinoceros. The specimen depicted is a young one.

Zebras, Pages 55.58. - The Zebras, of which there are funr recognised species, are readily distingui-bed by their prominently striped heads and bodies. All ale matives of Africa.

Common Zcbra (Ëuus scbra), Page 55-This animal, also known as the Mountain Zelra, is the first of the group, and is essentially a native of the lilly districts. Althongh called by the name "Common Zehra," this bedst is now one of the ralest, and is seldom seen in captivity. 
Burchell's Zebra (Equus burchelli), Page 56.-This species is a plain.dwellıng animal, and is still fairly plentiful. The greater majority of Zebras seen in captivity are of this kind.

Grevy's Zebra (Equus grevyi) Page 57.-1'lbis Zebra has only been known to science for the last fell years, and is easily distin. guished from other species, by the greater number of stripes (these being placed closer together), and by the larger size of its head.

Grant's Zebra (Equus granti), Page 58.- Grant's Zebra differs little from Burchell's Zebra, except in the slight variation of the striping. But as this difference is the most important distinguishing feature between the species, it has been recognised as distinct from the others.

Indian Elephant (Elephas maximus), Pages 59-6r.-Tbere are two species of Elephant, tbe Indian and the African. The former is the one alniost always seen in captivity, in fact, the only living specimen of the African Elephant now in England is to be seen at the London Zoo. The chief points of difference bet ween the two are to be fnund in the size of the ears, which in the African species are solarge as to cover the shoulder, whereas those of the Indian species are comparatively small; also the Indian Elephant has but one finger-like ending on the front edge of tbe trunk, whilst the African has two (one in front and the other behind). The highest point in the African Elephant is the shoulder, but with the Indian, the middle of the back.

American Grey Squirrel (Sciurus carolinensis), Page 62.This pretty little squirrel, as its name denotes, is grey in colour, though varietues are found in which the predominating hue is olivebrown. Like other squirrels it is extremely active and alert, and in confinement soon becomes tame and confiding. A number of animals of this species have lately been given their liberty at the Zoo, in the hope that they would establish themselves in the grounds and neighbouring park. Tbe experiment has proved satisfactory, many couples baving mated and reared offspring.

Elephantine Tortoise (Testudo eiephantina), Page 63.-Tbe Giant Tortoises come from the Galapagos Islands and Aldabra. Some scores have, during the last few years, come over to this country, and they are fast becoming extinct. However, it is pleasing to note that the few remaining species now receive protection by the hands of the Government of Mauritius, to which Aldabra belongs. The specimen depirted is estimated to be 200 years old, and its great size can readily be estimated by comparison with the small and average-sized tortoise upon its back.

Indian Python (Python molurus), Page 64.-The Pythons are the largest of the snakes, and it is by no means unusual to see one in captivity measuring 20 feet or more in length. They kill tbeir prey by crushing, swallowing it whole after it is dead. The photograph depicts the Indian Python.

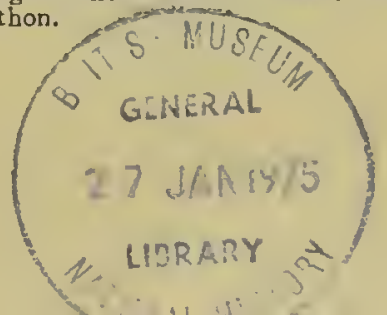




\section{LES CHEFS D'GEUVRE DE LA POÉSIE LYRIQUE * * FRANÇAISE * * *}

Selected, with Biographical Introductions, by AUGUSTE DORCHAIN, the well-known French Poet and Critic.

I. Les Chefs-d'CEuvre lyriques de Ronsard et de son Ecole.

2. Les Chefs-d'Cuvre lyriques d'Alfred de Musset.

3. Les Chefs-d'Cuvre lyriques d'André Chénier.

Others to follow.

These pretty little volumes contain the best poems, and those only, of the authors included.

\section{Price of each wolume:}

in parchment cover, $6 d$. net.; in cloth, $1 \mathrm{~s}$. net.; in leather, 2s. net.; postage, 1d. extrat.

GOWANS G GRAY, LTD., LONDON AND GLASGOW. 


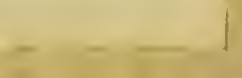


